UNIVERSIDADE DE SÃO PAULO

FACULDADE DE FILOSOFIA LETRAS E CIÊNCIAS HUMANAS

DEPARTAMENTO DE GEOGRAFIA

PROGRAMA DE PÓS-GRADUAÇÃO EM GEOGRAFIA HUMANA

Soraya do Carmo Souza

QUESTÃO AGRÁRIA E ETNOCONHECIMENTO CAMPONÊS NA COMUNIDADE PAU ROSA, ASSENTAMENTO TARUMÃ MIRIM, MANAUS-AM.

VERSÃO CORRIGIDA 
Soraya do Carmo Souza

\title{
QUESTÃO AGRÁRIA E ETNOCONHECIMENTO CAMPONÊS NA COMUNIDADE PAU ROSA, ASSENTAMENTO TARUMÃ MIRIM, MANAUS-AM.
}

\author{
VERSÃO CORRIGIDA
}

Dissertação apresentada ao curso de Pósgraduação em Geografia Humana da Universidade de São Paulo, como requisito parcial à obtenção do título de mestre em Geografia Humana com a orientação da professora Dra. Larissa Mies Bombardi.

Área de concentração: Geografia Humana. 
Soraya do Carmo Souza

\section{QUESTÃO AGRÁRIA E ETNOCONHECIMENTO CAMPONÊS NA COMUNIDADE PAU ROSA, ASSENTAMENTO TARUMÃ MIRIM, MANAUS-AM.}

Dissertação apresentada ao curso de Pósgraduação em Geografia Humana da Universidade de São Paulo, como requisito parcial à obtenção do título de mestre em Geografia Humana com a orientação da professora Dra. Larissa Mies Bombardi.

\section{BANCA EXAMINADORA}

Prof $^{\mathrm{a}}$ Orientadora: $\mathrm{Dr}^{\mathrm{a}}$. Larissa Mies Bombardi Instituição: FFLCH/USP

Componente da Banca: Prof ${ }^{a}$ Dra. Valéria de Marcos Instituição: FFLCH/USP

Componente da Banca: Prof. Reinaldo Corrêa Costa Instituição: LAES/INPA

São Paulo, 01 de julho de 2013. 
Autorizo a reprodução e divulgação total ou parcial deste trabalho, por qualquer meio convencional ou eletrônico, para fins de estudo e pesquisa, desde que citada a fonte.

Catalogação na Publicação

Serviço de Biblioteca e Documentação

Faculdade de Filosofia, Letras e Ciências Humanas da Universidade de São Paulo

S719q

Souza, Soraya do Carmo

Questão Agrária e Etnoconhecimento na Comunidade Pau Rosa, Assentamento Tarumã Mirim, Manaus-AM.. / Soraya do Carmo Souza ; orientadora Larissa Mies Bombardi. - São Paulo, 2013.

$144 \mathrm{f}$.

Dissertação (Mestrado) - Faculdade de Filosofia, Letras e Ciências Humanas da Universidade de São Paulo. Departamento de Geografia. Área de concentração: Geografia Humana.

1. Modo de Vida. 2. Questão Agrária. 3. Etnoconhecimento. 4. Plantas Medicinais. 5. Biodiversidade. I. Bombardi, Larissa Mies, orient. II. Título. 


\section{RESUMO}

O objetivo deste trabalho é a análise do modo de vida camponês na comunidade Pau Rosa no projeto de assentamento Tarumã Mirim, Manaus-AM. Uma das características do etnoconhecimento camponês é o conhecimento da natureza. Neste sentido, são notórios os saberes ambientais adquiridos para a produção de remédios com base em plantas retiradas da mata, cultivadas e/ou domesticadas nos quintais. $\mathrm{O}$ vasto conhecimento sobre $\mathrm{o}$ ambiente é resultado das experiências acumuladas em virtude das trajetórias de vida diversificadas, pela transferência de conhecimentos de geração em geração e por constantes pesquisas necessárias para o tratamento de doenças. As informações sobre o etnoconhecimento foram colhidas em entrevistas aos camponeses nos sítios e nas feiras onde comercializam a produção, com registro fotográfico dos elementos constituintes dos sítios e das plantas medicinais. O recurso da história oral foi utilizado pelo fato de as entrevistas serem de extrema importância para o conhecimento da realidade local, tendo em vista, a transmissão dos saberes da cultura camponesa ser com base na oralidade. Para o entendimento do modo de vida dos camponeses residentes na comunidade Pau Rosa foi preciso resgatar o contexto maior da qual fazem parte. Dessa forma, é preciso ressaltar as transformações da questão agrária amazônica, principalmente no pós década de 1960, período no qual ocorreu o incentivo à entrada de capital estrangeiro pelo Estado brasileiro, como estratégia para a ocupação da região. Para tanto, houve a necessidade de atrair mão de obra para os chamados "grandes projetos", constituindo assim o cenário favorável para o estímulo à migração. Com efeito, os migrantes são resultado da concentração fundiária no Brasil o qual fez emergir uma classe camponesa expropriada e em busca da terra de trabalho. $\mathrm{O}$ Estado, ao incentivar o campesinato sem terra a vir para a região diminuir-se-ia a pressão sobre a terra no país, no entanto, as comunidades locais foram menosprezadas, instaurando-se o conflito, resultado da ideia equivocada de vazio demográfico. A migração é, portanto, essencial para a compreensão da realidade local, na qual o camponês torna-se "posseiro" e passa a lutar pela terra negando a propriedade capitalista. O território camponês foi forjado no projeto de assentamento para reforma agrária a partir do etnoconhecimento. Dessa forma, os camponeses mantêm o etnoconhecimento dos seus modos de vida do ambiente de origem, as interações culturais possibilitaram um manejo da biodiversidade também pelos não amazônidas, assim, a identificação de espécies para fins medicinais e os remédios feitos a partir destas, retratam os saberes ambientais típicos das sociedades camponesas.

Palavras - chave: Modo de vida. Questão Agrária. Etnoconhecimento. Plantas Medicinais. Biodiversidade. 


\begin{abstract}
The aim of this study is the analysis of peasant life in the Pau Rosa community in Tarumã Mirim settlement project, Manaus-AM. One characteristic of peasant ethnoknowledge is knowledge of nature. In this sense, environmental wisdom acquired for the production of herbal medicines is notorious. The raw material for the preparation of medicines is taken from nature or grown in backyards. The vast knowledge about the environment is the result of accumulated experience because of varied life trajectories, by the transfer of knowledge from generation to generation and constant research of plant remedies and treatments for diseases. The ethnoknowledge information was collected in peasant interviews in places and fairs where they sell the production, with photographic record of the constituents of medicinal plants and places. The use of oral history was used because the interviews were extremely important for the local knowledge; in order to transmit the knowledge of peasant culture which is based on oral tradition. For understanding the way of life of the peasants that are resident in the community Pau Rosa was necessary to rescue the larger context of which it belongs. Thus, we must emphasize the transformation of the Amazonian agrarian issue, especially in the post 1960 period, when there was the incentive for foreign capital by the Brazilian state, as a strategy for the occupation of the region. Therefore, it was necessary to attract labor to the "big projects" and thus constitute the favorable scenario for the stimulus to migration. Indeed, migrants are the result of land concentration in Brazil which did emerge an expropriated peasant class in search of land and work. This movement characterized the agrarian geography of Amazonia, which means, move the landless peasantry to the region would decrease the pressure on land in the country, however, local communities have been neglected, strengthening the mistaken idea of demographic void. Migration is therefore essential to understand the local reality, in which the peasant becomes "posseiros" and goes on to fight for the land. The formation of a peasant territory was constituted in a settlement project for agrarian reform and ethnoknowledge is a striking feature of the Amazon peasantry. Thus, the peasantry resident in the Pau Rosa Community keeps traces on their lifestyles environmental of origin and cultural interactions which enabled a biodiversity management also by non Amazonians, so the identification of species for medicinal purposes and medicines made from these, depict the typical environmental wisdom of peasant societies.
\end{abstract}

Keywords: Way of life. Agrarian Question. Ethnoknowledge. Medicinal Plants. Biodiversity. 
Para Vanderley, o companheiro em todos os momentos...

\section{Dedicatória}

A minha bisavó, Nazaré Batista e a tia Leda que faleceram antes de ver o sonho realizado, a primeira pessoa da família a cursar o ensino superior. 


\section{AGRADECIMENTOS}

Aos camponeses da comunidade do Pau Rosa do projeto de assentamento Tarumã Mirim, pelo apoio e reciprocidade com que me receberam.

A minha família, meus pais Joaquim e do Carmo, irmãos Sara, Joaquim, Samara e Vitor pelo apoio.

A Larissa, pela orientação que me propiciou crescimento, apesar de saber que o caminho é longo e há muito que aprender.

Aos amigos Gustavo Cepolini e sua esposa Eliana, Ricardo Venturelli, Michell Tolentino, com quem pude compartilhar as descobertas ao longo da caminhada das disciplinas.

Aos amigos que me acompanharam nos trabalhos de campo à comunidade Pau Rosa, são eles: Márcia, Luciana, Renata, Wagner, Marília, Hilana, Zalina.

As instituições INCRA, SEPROR, IDAM, IPAAM, UFAM, pela atenção em no fornecimento das informações.

A Coordenação de Pós-Graduação, especialmente ao Firmino, Rosangela.

Ao professor Reinaldo Corrêa Costa que, muito contribuiu para a minha formação enquanto estudante de geografia. Foi no laboratório de estudos sociais onde dei os primeiros passos para conhecer a geografia agrária.

A todos que direta e indiretamente me apoiaram no decorrer do trabalho. 


\section{SIGLAS}

AFEAM - Agência de Fomento do Estado do Amazonas.

APOAM - Associação dos Produtores Orgânicos do Amazonas.

ASSAGRI - Associação de Agricultores do Pau Rosa.

CPRM - Companhia de Produção e Recursos Minerais.

DAS - Distrito Agropecuário da SUFRAMA.

EMBRAPA - Empresa Brasileira de Pesquisa Agropecuária.

EXPOAGRO - Parque de Exposições Agropecuárias Eurípedes Ferreira Lins.

FEPAGRO - Feira de Produtos da Agricultura Familiar.

FLOE - Floresta Estadual.

FLONA - Floresta Nacional.

IBAMA - Instituto Brasileiro de Meio Ambiente e Recursos Naturais Renováveis.

IBGE - Instituto Brasileiro de Geografia e Estatística.

IDAM - Instituto de Desenvolvimento Agropecuário e Florestal Sustentável do

Estado do Amazonas.

INCRA - Instituto Nacional de Colonização e Reforma Agrária.

INPA - Instituto Nacional de Pesquisas da Amazônia.

IPAAM - Instituto de Produção Ambiental do Amazonas.

LAES - Laboratório de Estudos Sociais.

MAPA - Ministério da Agricultura, Pecuária e Abastecimento.

PA - Projeto de Assentamento Federal.

PAE - Projeto de Assentamento Agroextrativista Federal.

PAF - Projeto de Assentamento Florestal.

PAM - Projeto de Assentamento Municipal.

PCA - Projeto de Assentamento Casulo.

PDS - Projeto de Desenvolvimento Sustentável.

PIC - Projeto Integrado de Colonização.

PIM - Pólo Industrial de Manaus.

PMDB - Partido do Movimento Democrático Brasileiro.

PR - Partido da República.

RDS - Reserva de Desenvolvimento Sustentável.

RESEX - Reserva Extrativista.

SEMPAB - Secretaria Municipal de Produção e Abastecimento. 
SEPROR - Secretaria de Estado de Produção Rural.

SIPRA - Sistema de Informações de Projetos de Reforma Agrária.

SUDAM - Superintendência de Desenvolvimento da Amazônia.

SUFRAMA - Superintendência da Zona Franca de Manaus.

UFAM - Universidade Federal do Amazonas.

ZFM - Zona Franca de Manaus. 


\section{SUMÁRIO}

Introdução.

CAPÍTULO I - ESPAÇO AGRÁRIO AMAZÔNICO, CONFLITOS E APROPRIAÇÃO DO TERRITÓRIO.

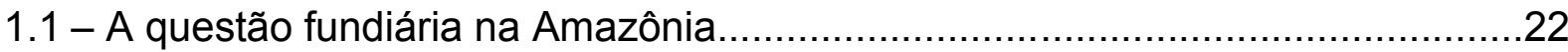

1.2 - Políticas desenvolvimentistas para a Amazônia...........................................25

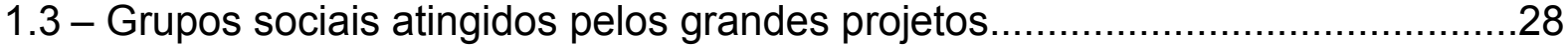

1.4 - Reconfiguração camponesa na Amazônia.......................................................31

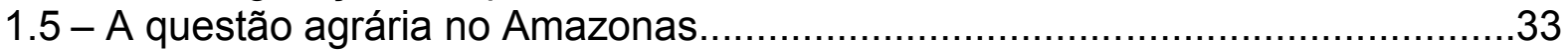

CAPÍTULO II - ASSOCIAÇÃO COMUNITÁRIA PAU ROSA..............................38

2.1 - O P. A. Tarumã Mirim, um assentamento entre rias fluviais...........................47

2.2 - Sobreposições de territorialidades: unidade de conservação versus projeto

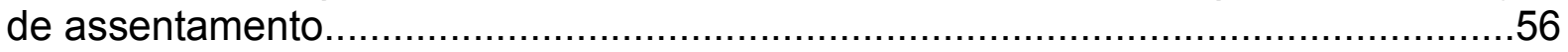

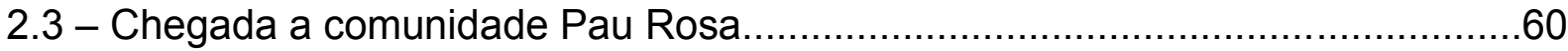

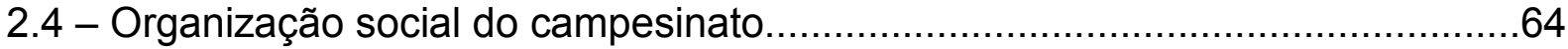

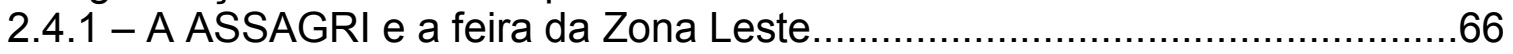

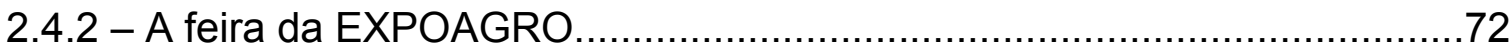

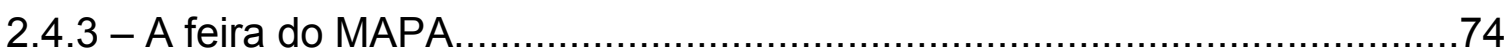

2.5 - Especulação imobiliária..........................................................................

CAPÍTULO III - ETNOCONHECIMENTO, CULTURA E PLANTAS

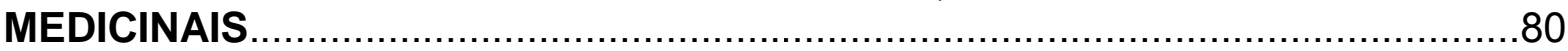

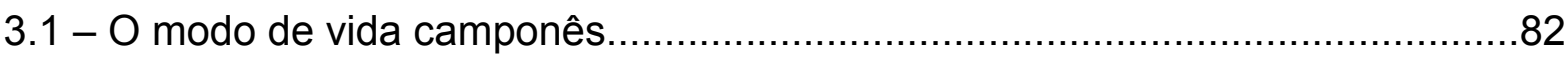

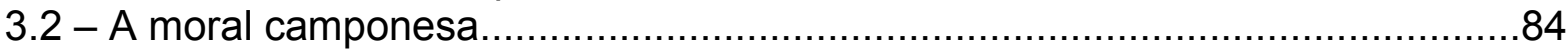

3.3 - O tempo para plantar...............................................................................

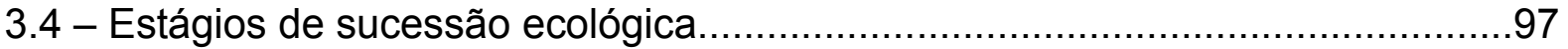

3.5 - As políticas para as plantas medicinais..................................................116

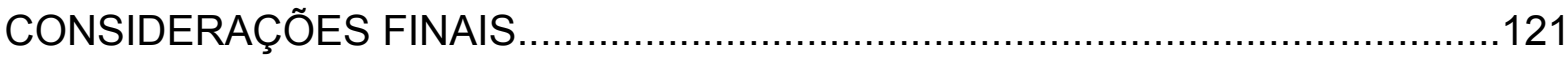

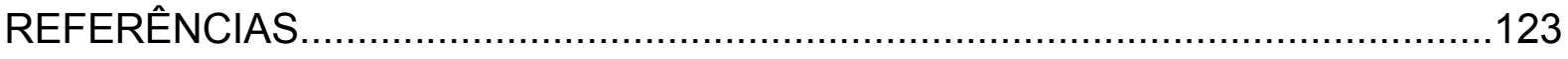

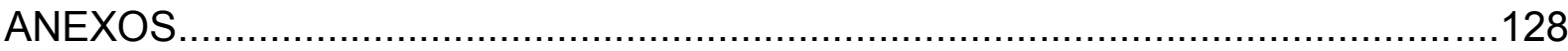




\section{INTRODUÇÃO}

A questão agrária brasileira se apresenta como uma realidade plural e multifacetada. De norte a sul do país encontramos os mais diversificados processos. Os quais estão intimamente ligados. Concentração fundiária, conflitos, expropriação e a luta pela terra fazem parte deste cenário.

A acumulação de capital se dava em nível extremamente danoso aos grupos sociais que já habitavam o território, os quais foram desconsiderados do planejamento econômico proposto para desenvolver o país.

Nessas circunstâncias surge a figura do posseiro e do latifundiário. Martins (1995) define o posseiro como o lavrador que trabalha na terra sem possuir nenhum título legal, nenhum documento reconhecido legalmente e registrado em cartório que o defina como proprietário, oficialmente é designado como ocupante da terra.

O "grileiro" trata-se de quem se assenhoreia de uma terra que não é sua, sabendo que não tem direito a ela, e através de meios escusos, suborno e falsificação de documentos, obtém os papéis que o habilitam a vender a terra. É um traficante de terras (MARTINS, 1996).

Esses personagens são centrais, juntamente com os indígenas, para explicar os conflitos agrários na Amazônia. O grileiro vende terras públicas para fazendeiros, adentrando em muitos casos, terras indígenas e as "posses". Este cenário desencadeou os conflitos pela terra na Amazônia.

Nesse contexto, índios e camponeses, representavam o atraso de uma sociedade enquanto o ideal era tornar o país moderno, dito de primeiro mundo, desenvolvido.

No entanto, para formar tal sociedade era necessário implantar indústrias, para tanto era essencial mão de obra e oferta de matéria prima. Neste cenário, a Amazônia surge como a grande expressão de grandiosidade, os recursos naturais seriam a chave para trazer o tão propalado desenvolvimento para a região, e num tom nacionalista, desenvolver a região traria proteção para as fronteiras do país. (GONÇALVES, 2010; MARTINS, 1995; OLIVEIRA, 1987).

Esta postura do governo atraiu tanto o capital estrangeiro quanto as mazelas sociais. Por toda a região, foram implementados projetos mínero-metalúrgicos e agropecuários. O latifúndio se instalou na região, estimulado pelas políticas de incentivos fiscais (GONÇALVES, 2010). 
Pode-se afirmar então ter sido o planejamento estatal o principal responsável pelas transformações ocorridas na Amazônia no pós década de 1970. Dentre estas, cabe destacar a expropriação de terras camponesas, remoção de grupos indígenas, retirada de floresta nativa para a formação de fazendas e retiradas de minérios.

O conflito envolvendo a posse e o domínio da terra foi determinante nas últimas décadas. O deslocamento de famílias por causa da pressão feita pelos grandes proprietários tornou-se cada vez mais violenta. Em contrapartida, os camponeses passaram a se organizar e lutar pelos seus interesses (MARTINS, 1995).

Em se tratando de uma região de dimensões continentais, torna-se tarefa difícil esgotar as problemáticas que envolvem a questão agrária na Amazônia. Com efeito, é necessário abordar qual ou quais Amazônia(s) estamos falando.

Tal diferenciação é importante para desmistificar a ideia corrente de vê-la apenas como uma região de grande potencial econômico, mas, com uma população incapaz de geri-la. A conceituação de Amazônia pode ser feita de várias formas. A mais usual é a delimitação por fatores naturais. No entanto, Ab' Sáber (1994:79) enfatiza a setorização da região em células espaciais considerando a diversidade natural e social,

\begin{abstract}
Para viabilizar as ideias e estratégias para uma convivência espacial entre os povos e comunidades dotadas de culturas muito diversas para uma convivência espacial entre povos e comunidades dotadas de culturas muito diversas, sugere-se um esforço de setorização e inventário de conjunturas, dirigido para a Amazônia, vista como um todo. Preconizamos a feitura de um diagnóstico que envolva o conhecimento das condições ecológicas e sócio-econômicas de cada uma das grandes células espaciais identificáveis na região.
\end{abstract}

Para Gonçalves, existem múltiplas Amazônias, mas o fundamental é pensar na vida dos povos,

Há várias Amazônias na Amazônia, muitas delas contraditórias entre si. Há aquelas que tornem possível uma vida melhor, não só para os seus habitantes, mas também para o planeta. Poucas são as regiões do mundo que têm esse trunfo. E esse caminho passa necessariamente por incorporar suas populações aos direitos básicos de cidadania, oferecendo-lhes condições para fazerem melhor o que já sabem, além, de buscar novos caminhos a partir da experiência acumulada. A Amazônia exige uma visão complexa do meio ambiente que não dissocie ecologia de justiça social, da cidadania. $(2010$, p.10) 
Os elementos que a compõem, principalmente no pós década de 60 , fazem/fizeram parte de políticas que desconsideraram a natureza e a cultura dos índios e camponeses. Ao grande capital, naquele momento, estes povos representavam um empecilho ao "desenvolvimento" (OLIVEIRA, 1987, 2005).

É nesta realidade, tão fortemente marcada pela sanha avassaladora do capital, que a posse se inscreve na contramão da dominação (OLIVEIRA, 1987). A posse, aparentemente subversiva, é o sinal da resistência, porque na lógica camponesa, a terra deve ser partilhada.

Esta situação é recorrente por toda a Amazônia, e neste trabalho propomonos a demonstrar como ocorre a reprodução da família camponesa no interior de um projeto de assentamento para reforma agrária, utilizando como base o etnoconhecimento.

Pode-se afirmar que os saberes ligados à natureza são de grande valia para os camponeses, para usufruir de forma a não comprometer os recursos para os seus descendentes. Isto faz parte do modo de vida, aqui empregado no sentido que Marx utilizou na obra A ideologia alemã (1932, p.44),

\begin{abstract}
A forma pela qual os homens produzem seus meios de vida depende sobretudo da natureza dos meios de vida já encontrados e que eles precisam reproduzir. Não se deve, porém considerar tal modo de produção de um único ponto de vista, ou seja, a reprodução da existência física dos indivíduos. Trata-se muito mais de uma forma determinada de atividades dos indivíduos, de uma forma determinada de manifestar sua vida, um modo de vida determinado. Da maneira como os indivíduos manifestam sua vida, assim são eles. O que eles são coincide, portanto, com sua produção, tanto com o que produzem como com o modo como produzem. O que os indivíduos são, por conseguinte, depende das condições materiais de sua produção.
\end{abstract}

A terra própria representa a reconquista da autonomia, em certos casos, perdida. O ideal seria depender o mínimo do mercado. Nesse sentido, os conhecimentos tradicionais auxiliam para a diminuição dos custos com medicamentos.

Esta prática é tida como um "saber ambientalmente correto", consideramos, no entanto, que todas as práticas desencadeiam, em menor ou maior proporção, impactos ao ambiente. A diferença é a forma como determinadas classes fazem o uso do ambiente.

Para a classe camponesa, a terra é essencial para a reprodução de seu modo de vida. E a terra é o principal meio de produção, é onde se realiza o trabalho da 
família, mas não se trata somente disso, ela é também patrimônio, como observado em Woortmann (1990, p.43), [...] o significado da terra é o significado do trabalho e o trabalho é o significado da família, como o é, igualmente, a terra enquanto patrimônio. Mais do que objeto de trabalho, a terra é o espaço da família.

A natureza é o elemento essencial para o planejamento das atividades. As práticas ligadas ao etnoconhecimento requerem a presença de vegetação. Para tanto, a manutenção da cobertura vegetal é importante para o manejo do solo e para garantir os ingredientes para a produção de remédios caseiros.

A cultura camponesa presente em um projeto de assentamento é diversificada. Sofreu/sofre influências culturais, seja por causa dos processos migratórios ou mesmo porque as sociedades camponesas não são estáticas, paradas no tempo, fadadas ao fracasso e ao desaparecimento. Elas se reinventam e aprendem com os ensinamentos dos ancestrais, pesquisam com os vizinhos e em programas de televisão. Assim, há a mescla de conhecimentos repassados de geração em geração com o conhecimento difuso, o saber popular.

Diante do exposto, este trabalho se insere no estudo acerca do etnoconhecimento camponês no projeto de assentamento federal Tarumã Mirim. As influências relativas ao contexto da questão agrária, nacional e regional, não podem ser negligenciadas, devido às ricas trocas de saberes estarem vinculadas à diversidade de origem das pessoas.

Neste sentido, o processo de migração camponesa em direção à Amazônia se explica principalmente pelo fato da estrutura agrária brasileira ser altamente concentrada. A especulação do preço da terra em regiões consideradas nobres torna cada vez mais difícil a reprodução da família camponesa. Para tanto, a solução é migrar (MARTINS, 1991; OLIVEIRA, 2007).

Para explicar o contexto em que se situa a migração camponesa no assentamento Tarumã Mirim é preciso fazer um resgate da questão agrária Amazônica que foi/é influenciada por processos em nível nacional. É sob este enfoque que o primeiro capítulo foi elaborado. O espaço agrário amazônico será explanado a partir das transformações ocorridas, principalmente no pós década de 1960, no qual as situações de conflito se tornaram latentes, a ponto de confrontos armados passarem a expor as fragilidades de uma região até então encarada como exótica, recebendo denominações de "inferno verde" ou mesmo a comparações com 
cidades europeias, assim como Manaus que foi denominada a "Paris dos Trópicos" (OLIVEIRA, 1987, TOCANTINS, 1961).

A Amazônia era vista a partir de comparações com o que a estrutura dominante impôs como ideal, e não a partir de suas peculiaridades. É objetivo neste primeiro capítulo, abordar a Amazônia a partir da conjuntura maior da qual faz parte, situando o leitor na compreensão do contexto histórico da apropriação das terras públicas e as consequências nefastas da ação dos latifundiários sobre camponeses.

Isto se faz necessário para introduzir a questão da necessidade da migração dos camponeses até a chegada à Manaus e posteriormente, à área do Tarumã. Foram afetados, portanto, pelas políticas de integração nacional.

No segundo capítulo abordaremos a formação da Associação Comunitária Pau Rosa, enfatizando a infraestrutura e as transformações próprias da sociedade. Esta comunidade é uma das que integram o PA Tarumã Mirim. O acesso lhe confere características que a diferenciam das demais, porque a acessibilidade, na medida em que contribui para a melhoria do deslocamento dos camponeses, também fomenta a especulação imobiliária.

Para a compreensão de tais processos é preciso situar a comunidade Pau Rosa no contexto de criação do PA Tarumã Mirim, que foi criado onde já existiam posses. Ao ser regularizado, seria um potencial produtor de alimentos para abastecer o crescente mercado consumidor manauara, no entanto, infraestrutura precária, falta de fertilidade natural dos solos e falta de apoio técnico financeiro aos assentados impediu o pleno desenvolvimento das atividades. Está distante da área urbana de Manaus $21 \mathrm{~km}$, tornando-se alvo da expansão dos sítios de lazer.

No terceiro capítulo será explanada a resistência camponesa ao modelo dominante de apropriação dos espaços herdados da natureza, que está associada diretamente a um modo de vida no qual a família, o trabalho e a terra são os elementos centrais (WOORTMANN, 1990).

Neste sentido, a possibilidade de se conseguir a terra de trabalho, por se tratar de camponeses pobres, é pela posse em terras públicas e por meio dos projetos de assentamento. A terra, além de unidade produtiva é patrimônio da família, nessa perspectiva, os camponeses estabelecem vínculos respectivos a uma ordem moral.

As tradições referentes ao cultivo, ao uso de elementos da natureza são repassadas oralmente de geração em geração. No campesinato residente na 
comunidade Pau Rosa é notório o uso de plantas medicinais para a resolução de problemas de saúde e para a venda em mercados de Manaus.

As plantas fazem parte do cotidiano dos camponeses assentados para o preparo de remédios, rituais e para o embelezamento da casa. A presença da família em casa é imprescindível para a realização das atividades produtivas. Por isso, as enfermidades curadas no âmbito doméstico evitam o deslocamento até a cidade, além do que, os remédios com base em plantas são considerados mais confiáveis do que os comercializados em farmácias.

\section{O trabalho de campo}

As primeiras aproximações com a área de estudo foram feitas através de um projeto de iniciação científica, sob a orientação do professor Reinaldo Correa Costa, realizado no período de 2006 a 2008 no Instituto Nacional de Pesquisas da Amazônia (INPA).

O referido projeto de iniciação científica fez parte do meu Trabalho de Conclusão de Curso (TCC) para obtenção do grau de bacharelado do curso de Geografia na Universidade Federal do Amazonas (UFAM).

Isto posta, que esta pesquisa foi pensada no sentido de contribuir para a reflexão da questão agrária do estado do Amazonas. Tendo como objeto de estudo a comunidade Pau Rosa do Projeto de Assentamento Tarumã Mirim, no município de Manaus.

É objetivo neste trabalho desvelar como acontece a reprodução da família camponesa na comunidade Pau Rosa. É notório no modo de vida dos camponeses o etnoconhecimento associado aos elementos da natureza para a resolução de problemas de saúde e espirituais.

Os remédios preparados a partir de plantas medicinais são produzidos com base nos conhecimentos herdados dos antepassados, e também, com pesquisas entre os conhecidos, conforme a enfermidade a qual se procura a cura. Existindo, nestes casos, as trocas de saberes. Esta prática ficou evidente quando a Sra. R.S., a primeira entrevistada, nos mostrava as plantas pelo quintal e à beira da estrada, e nos contava que o caminho para a descoberta daquele remédio, foram as doenças do marido ao longo da vida. 
As informações foram obtidas em trabalhos de campo nos sítios em que moram e nas feiras onde os próprios camponeses comercializam a produção. A primeira feira visitada foi a feira municipal do produtor da Zona Leste, conhecida popularmente como "feira do produtor do bairro Jorge Teixeira". Em seguida, a feira do Parque de Exposições Agropecuárias (EXPOAGRO) e a "feira do MAPA", onde a APOAM (Associação dos Produtores Orgânicos do Amazonas) comercializam a produção no estacionamento do Ministério da Agricultura, Pecuária e Abastecimento (MAPA).

Os depoimentos são importantes por retratar, em certos aspectos, o que a rigidez dos números deixa encoberta. Por isso, os recursos da história oral são valiosos no sentido de descobrir a essência da vida camponesa. O olhar nos olhos, os desenhos rabiscados no chão para explicar algo, são fatos que fogem às estatísticas. Para resguardar a identidade de alguns dos entrevistados optou-se por utilizar as iniciais dos respectivos nomes. Em certos casos, os camponeses faziam questão de se identificar, assim, o registro fotográfico seria uma prova do que estaria sendo plantado.

Contei com a colaboração de colegas vinculados ao Laboratório de Estudos Sociais (LAES) do INPA para os trabalhos de campo. Os mesmos foram iniciados em 2011 nos meses de junho, julho, agosto e setembro, onde fiquei hospedada na escola Neusa dos Santos Ribeiro. Os trajetos eram feitos no ônibus da escola que trafega somente no interior do assentamento. Nos lugares onde o ônibus não trafega e nos dias sem aula se faziam os percursos a pé.

Em 2012, fizemos os trabalhos de campo em um mês, retornando todos os dias a Manaus. Paralelamente se fazia pesquisas bibliográficas e visitas em instituições públicas para a coleta de informações, tais como INCRA, IPAAM, SEPROR/IDAM, UFAM. Nos fins de semana, realizamos os trabalhos de campo nas feiras do produtor, SEPROR e do MAPA. 


\title{
CAPÍTULO 1 - ESPAÇO AGRÁRIO AMAZÔNICO, CONFLITOS E APROPRIAÇÃO DO TERRITÓRIO.
}

Neste primeiro capítulo busca-se refletir sobre a questão agrária na Amazônia. A região apresenta realidades distintas, seja à escala dos estados federativos ou mesmo a nível municipal. Por isso, é possível afirmar tratar-se de uma região heterogênea. As relações sociais que possibilitaram sua construção foram profundamente alteradas a partir da década de 1960, com o Estado brasileiro e o capital atuando conjuntamente.

A ideia equivocada de "vazio demográfico" ou a negação da cidadania às populações camponesas engendrou diversos conflitos em torno da posse e domínio das terras públicas. Isto para a implantação dos chamados "Grandes Projetos". Para Martins (1991, p.73),

\begin{abstract}
A doutrina de ocupação dos espaços vazios produz concretamente, pelo caminho que está sendo seguido, o esvaziamento dos espaços ocupados. A Amazônia não é um deserto a ser ocupado. Na pressuposição dos tecnocratas não entrou um dado prévio sobre a já existente ocupação da Amazônia por índios e posseiros e muito menos entrou em cogitação o povoamento da região que se daria em consequência das próprias medidas da política econômica concentracionista aplicadas no conjunto do país, expulsando lavradores em direção às terras amazônicas, forçados a disputá-las com as grandes empresas que recebem incentivos fiscais do governo. Com isso, o posseiro se defronta com um processo reiterativo de expulsão, que passa a constituir um dado de importância para entendermos a sua resistência crescente e obstinada à expropriação. (grifo nosso).
\end{abstract}

O trecho em destaque desperta interesse por retratar exatamente o contrário da conceituação do Instituto Nacional de Colonização e Reforma Agrária (INCRA), acerca da colonização da Amazônia,

\footnotetext{
O Instituto Nacional de Colonização e Reforma Agrária - INCRA é uma autarquia Federal criada na década de 70 com o objetivo inicial de promover a ocupação dos espaços vazios do território nacional, principalmente na Amazônia, por meio de processos de regularização fundiária. Uma de suas principais atribuições, no entanto, sempre foi a de redistribuir terras obtidas pelo atributo constitucional da desapropriação. (NEVES, 2011, s/p).
}

Para Hébette (2004, p.24), os dois eixos viários responsáveis pela entrada dos empreendimentos de integração econômica da Amazônia foram a Belém Brasília e a Cuiabá - Porto Velho - Rio Branco (BR 364), 
Outras estradas se seguiram às primeiras: a Transamazônica (Terra sem homens para homens sem terra), a Perimetral Norte, falida. Latifúndios se espalharam em toda a Amazônia: Jari, Volkswagen, Bradesco. Minas e garimpos reviraram o solo; rios foram represados para formar lagos imensos e gerar energia elétrica; fábricas poluidoras surgiram na selva. O grande capital penetrou nas áreas indígenas, cortou as reservas, lavrou o subsolo, alagou aldeias; a cultura tradicional dos índios foi ferida, a sua liberdade ancestral foi ameaçada. O latifúndio engole as roças, mas o camponês resiste à expulsão, recusa a proletarização, luta contra o cativeiro e defende sua autonomia.

Diante desse quadro, pode causar estranheza a presença de empresas conhecidas em outros ramos da economia investindo em projetos agropecuários e minero-metalúrgicos, formando latifúndios e recebendo incentivos fiscais. Para Oliveira (2007) a modernização da agricultura não transformou o latifundiário em capitalista, mas teve efeito inverso, transformou os capitalistas industriais e urbanos em latifundiários na Amazônia. Martins (1991, p.16) explica que isso ocorre porque "[...] o capitalismo articula num só tempo, ainda que em espaços distintos, a expropriação e a exploração, processos que a rigor, se deram separadamente na história clássica do capital".

Isto em parte foi desencadeado pelo Estado, seja pela sua ausência ou presença. Os planos de governo favoreceram o capital nacional e internacional, conforme aponta Ab' Sáber,

Por dezenas de anos, a partir da década de 1960, a Amazônia foi apresentada ao mundo ocidental como uma região uniforme e monótona, pouco compartimentada e desprovida de diversidade fisiográfica e ecológica. Enfim, um espaço sem gente e sem história, passível de qualquer manipulação por meio de planejamentos realizados à distância ou sujeitos a obras faraônicas, vinculadas a um falso conceito de desenvolvimento. (2003, p.81).

\section{Corroborando com o pensamento de Gonçalves,}

Nos últimos anos, particularmente a partir dos anos 1960, com a abertura da Rodovia Bernardo Sayão, a Belém-Brasília, e da criação da Superintendência da Zona Franca de Manaus, a Amazônia vem passando por um intenso processo de transformações na organização do seu espaço geográfico. Toda a política a partir de então posta em prática estava embebida neste imaginário. O futuro parecia, finalmente, ter chegado à Amazônia. Para isso, o Estado brasileiro, então sob o regime ditatorial militar, recorreu a empréstimos em bancos privados e multilaterais (BID e BIRD - Banco Interamericano de Desenvolvimento e Banco Mundial), além de grandes corporações transnacionais, renunciou a impostos beneficiando grandes empresas, além de oferecer outros incentivos fiscais aos que 
procurassem se associar a esse esforço elaborado por gestores territoriais civis e militares, nessa verdadeira missão de incorporar a Amazônia (2010, p.12).

Esta região passou a figurar como essencial no contexto local/mundial de acumulação de capital. Encarada como reserva de recursos, foi utilizada como garantia para a realização de empréstimos junto a organizações internacionais, notadamente no regime ditatorial.

A busca desenfreada pelo "desenvolvimento e progresso" fez da região o palco de intensos conflitos entre os grupos sociais que já habitavam a região e os que vieram atraídos pela perspectiva promissora que ora se apresentava. A realidade foi o conflito armado, a expulsão de posseiros e a ação do latifúndio num escandaloso caso de incentivo à chamada "ocupação da Amazônia", como destaca Arbex Jr. (2005, p. 37),

A ditadura militar (...) construiu uma imagem de Amazônia como se fosse uma "nova terra de oportunidades" exposta apenas à ousadia e determinação de aventureiros; celebrou a "força do homem contra a natureza, simbolizada pela motosserra e por grandes obras como a Transamazônica; acentuou os traços mais perniciosos e catastróficos da mentalidade colonialista com relação à Amazônia.

No estudo realizado na estrada Transamazônica BR 230, no estado do Pará, desde o rio Araguaia até o rio Tapajós, (HÉBETTE; ALVES; QUINTELA, 2002, p.179) descrevem o processo migratório do campesinato associado às políticas de integração econômica estatal e a luta para permanecer na terra.

O fluxo migratório constituído por pequenos camponeses encontrou em seu caminho os detentores de imensas florestas e outros grandes proprietários, que vieram reproduzir nas frentes as fazendas e latifúndios que caracterizam a estrutura fundiária brasileira. Durante mais de duas décadas, os colonos da região do Tocantins-Araguaia não puderam se manter nesta terra senão através de uma verdadeira guerra que os confrontava com os latifundiários e a suas instituições (jurídicas, políticas, militares e policiais) de apoio. O camponês da frente precisou assumir, durante este período, o duplo papel de agricultor e de combatente que a história, em geral, tendeu a dissociar (DUBY, 1977; MUNFORD, 1964). Se, como escreveu LABORIT (1971, p. 71), referindo-se a Munford, a propósito dos camponeses da Idade Média, e se, como o veicula ainda toda uma representação do tipo "Séculos de uma existência tranquila fizeram dos aldeões seres pacientes e acomodados" (tradução nossa), a frente pioneira amazônica, pelo menos, demonstrou e estimulou a combatividade e o espírito de luta. 
A pressão sobre a terra é acompanhada pelo aumento dos conflitos, Martins (1991, p.86) descreve a gravidade da situação.

Em 1974, os conflitos pela terra ocorriam principalmente em outras regiões do país. Entretanto, já em 1975 e 1976, 60\% dos conflitos pela terra ocorreram na Amazônia, sendo que $76,5 \%$ dos conflitos graves, os que tiveram mortos e feridos, nela se deram. Não só cresce na região o número de conflitos pela terra, mas nela cresce o número de conflitos graves. Dos conflitos graves pela terra, ocorridos no país em $1976,82 \%$ se deram na Amazônia. Do mesmo modo, $90 \%$ dos mortos nesses confrontos correspondem à região amazônica nesse ano. É clara a relação entre o incremento da ocupação empresarial da Amazônia e o crescimento dos conflitos. Em 1971/72 somente $8 \%$ dos conflitos graves ocorreram naquela região, correspondendo-lhes $6 \%$ do total das vítimas (mortos e feridos).

O fato é que herdamos as consequências da concentração fundiária que perdura em nossa sociedade, sobretudo quando o assunto é referente às terras públicas. Isto porque o Estado empreendeu uma política de colonização numa região considerada como um "vazio demográfico" como salientou Carlos Walter, com ressalvas, visto todo um discurso nacionalista em torno da ocupação da Amazônia para fins de desenvolvimento,

Para Gonçalves (2010, p.33) é preciso explicar que,

Antes de qualquer coisa, o conceito de densidade demográfica é um conceito relativo em pelos menos dois sentidos. O primeiro é que a relação população-área deve ser equacionada com relações sociais que regem a vida dos homens e mulheres entre si e destes com a natureza. A própria Amazônia, sempre apontada como uma região de baixa densidade demográfica, em vários momentos de sua história, apresentou uma superpopulação relativa, em virtude de mudanças do contexto socioeconômico. Referimo-nos aqui, em particular, à crise decorrente da perda da liderança na produção de látex que provocou o êxodo das populações dos estados amazônicos, sobretudo entre os estados da própria região. Em segundo lugar, o conceito de densidade demográfica torna-se mais evidentemente relativo quando a ele se associam valores-padrão de baixo ou alto. Afinal, a densidade demográfica da Amazônia é baixa em relação a quê, se em determinadas circunstâncias há até população excedente? Aqui se evidencia claramente que, subjacente à ideia de vazio demográfico, se esconde aquela preocupação já salientada, herdada do período colonial, que revela mais a respeito das dificuldades dos que querem colonizá-la em realizar o seu intento do que propriamente do povoamento da região. É a ideia de vazio demográfico frequentemente reiterada como que para justificar a necessidade de ocupá-la, para garantir a integridade territorial.

Mas, era habitada por grupos sociais que representavam tudo o que se queria eliminar, o atraso. Buscava-se inserir os estados amazônicos, no pós década de 1960, num ideal de civilização do qual os povos tradicionais não faziam parte. 
As propostas de exploração mineral, madeireira e pecuária eram destinadas a quem detivesse o grande capital. Empresas multinacionais foram contempladas pelos projetos e financiamento. Os nordestinos, principalmente do Ceará e Maranhão, foram recrutados para servirem de mão de obra, trabalhando em condições degradantes de semiescravidão. Oliveira (2007, p. 132) afirma tratar-se da acumulação primitiva de capital,

\begin{abstract}
A política de incentivos fiscais da SUDENE e SUDAM foi o instrumento econômico que viabilizou essa fusão (capitalistas em proprietários). Dessa forma, os capitalistas urbanos tornaram-se os maiores proprietários de terra no Brasil. [...] É em decorrência desse processo que se tornou possível a revelação de dois aspectos contraditórios destes capitalistas modernos: a mesma indústria automobilística que pratica as mais avançadas relações de trabalho do capitalismo no Centro-Sul, na Amazônia, ao contrário, praticava em suas propriedades agropecuárias a peonagem, relação de trabalho também chamada de "escravidão branca".
\end{abstract}

Martins associa o aumento dos conflitos na Amazônia com a concentração fundiária e a instalação das empresas,

Para a Amazônia estão se deslocando, portanto, contingentes populacionais desalojados por uma estrutura fundiária concentracionista e expropriatória, agravada por uma política governamental de franca opção pela grande empresa e pela propriedade capitalista da terra. A Amazônia é hoje uma das regiões mais tensas do país exatamente porque nela estão se acumulando tensões geradas em outras áreas, ao mesmo tempo em que a reprodução deliberada e exacerbada da estrutura fundiária concentracionista que expulsa lavradores e trabalhadores rurais, faz dela uma região de desespero. (1982 p.86)

A tentativa de se resolver as tensões sociais do restante do país incentivando a migração para Amazônia foi um desastre. Ao invés de sanar o problema criaramse outros. O campesinato expropriado continuava a se deslocar em busca de terra e assim não se resolveu o problema histórico da reforma agrária no país. 


\subsection{A questão fundiária na Amazônia.}

A compreensão do conflito pela terra na Amazônia tem como principal causa a política de destinação de terras do Brasil Colônia. Martins (1995) faz um resgate histórico acerca da formação da propriedade privada da terra do século XVI ao XVIII. Neste período a concessão de terras, sesmarias, estava condicionada à quantidade de escravos. A relação entre possuir escravos e requerer terra se baseava na presença de trabalho na propriedade. A terra sem sinais de trabalho poderia ser requerida por novo sesmeiro, como afirma Martins (1991, p.64),

[...] A efetiva ocupação da terra, com trabalho, constituía o requisito da apropriação, revertendo à Coroa o terreno que num certo prazo não fosse trabalhado. Num país em que a forma legítima de exploração do trabalho era a escravidão, e escravidão negra, os "bastardos", os que não tinham sangue limpo, os mestiços de brancos e índias, estavam destituídos do direito de herança, ao mesmo tempo em que excluídos da economia escravista. Foram esses os primeiros posseiros: eram obrigados a ocupar novos territórios porque não tinham lugar seguro e permanente nos territórios velhos.

Com o fim da escravidão, a terra passa a ser "cativa". Segundo Martins (1996, p. 32) "[...] A renda capitalizada no escravo transformava-se em renda territorial capitalizada: num regime de terras livres, o trabalho tinha que ser cativo; num regime de terras livres, a terra tinha que ser cativa". A terra era elemento secundário, o escravo era o principal, por ser ao mesmo tempo renda territorializada e antecipada.

A Lei de Terras de 1850 definitivamente torna a propriedade objeto de compra. Isso quer dizer, só quem dispõe de capital suficiente pode ser dono de terras. A população pobre fica alijada do processo de obtenção de propriedades, conforme visto em Martins (1991, p.65).

[...] A Lei de Terras instituiu um novo regime de propriedade em nosso país, que é o que tem vigência até hoje, embora as condições sociais e históricas tenham mudado muito desde então. Ao contrário do que se deu nas zonas pioneiras americanas, a Lei de Terras instituiu no Brasil o cativeiro da terra - aqui as terras não eram e não são livres, mas cativas. A Lei 601 estabeleceu em termos absolutos que a terra não seria obtida por outro meio que não fosse o da compra.

O regime de sesmarias, extinto em 1922, era o meio legítimo de obtenção de terra. Deveria ter sido superado pela Lei de Terras de 1850, mas ainda hoje é 
utilizado como artifício legal para comprovação de títulos de propriedade em litígio. Para Motta (2009, p.263)

[...] Em muitos dos conflitos fundiários ocorridos no oitocentos (e ainda hoje), a carta de sesmaria foi e tem sido utilizada para construir um ponto zero na história da ocupação territorial na área em disputa. Ao lançar mão de um documento tão antigo, uma das partes (ou as duas) chama a história e consagra, ao menos aos olhos da lei, a legalidade de sua ocupação.

\section{É emblemático o fato descrito por Motta (2009, p.263) referente à grilagem de uma extensa área no Pará, o jornal O Globo}

[...] denunciava a "maior fraude fundiária da história do país", a grilagem de $1 \%$ do território nacional realizada por um fazendeiro. São nove milhões de hectares de terras públicas em 32 municípios no Pará, capazes de abrigar a população de Portugal que reúne cerca de nove milhões de pessoas, num território correspondente a uma ínfima parte do Brasil. O jornal não deixava de relatar o empenho do procurador do Estado, Carlos Lamarão, que, nos últimos vinte anos tentou sem sucesso reincorporar o território ilegalmente ocupado por aquele fazendeiro. $O$ interessante e dramático dessa história era o fato de que a grilagem estava calcada na invenção de um ponto zero na história da ocupação daquela área: a existência de cartas sesmarias, doadas pela Coroa a dois portugueses: Manoel Joaquim Pereira e Manoel Fernandes de Sousa.

Tantos foram os casos de escândalos envolvendo a apropriação de terras devolutas que a Comissão Parlamentar de Inquérito de terras públicas da Amazônia teve que fazer um levantamento sobre a cadeia dominial das terras constituídas em latifúndios. Constataram-se diversas irregularidades na obtenção de terras, de acordo com o relatório da CPI (2000, p.36),

\footnotetext{
Cabe destacar que a responsabilidade destas irregularidades cabe aos Oficiais Registradores, observado e concluindo, que grande parte destes despautérios e excessos cometidos, também são produto da ausência quase total de uma fiscalização sistemática e efetiva das Corregedorias Estaduais de Justiça, que se há mantido ausente nos últimos dez ou vinte anos. Chegando ao cúmulo dos casos de duas áreas registradas no Cartório de Canutama, Amazonas, a Fazenda Eldorado e Santa Maria, com uma área de UM BILHÃO E QUINHENTOS MILHÕES DE HECTARES; e a outra, a Fazenda Boca do Pamafari, com uma área de DOZE BILHÕES DE HECTARES.
}

O caso citado demonstra os desmandos de usurpação do patrimônio público. A fazenda Eldorado teria uma superfície equivalente ao estado do Amazonas enquanto a fazenda Santa Maria seria maior que o Estado brasileiro. Para a CPI, estes episódios têm respaldo na mesma legislação, 
[...] já arcaica e ineficaz no início da colonização, regeu a ocupação do Centro-Oeste e da Amazônia, na segunda metade do século XX. Multiplicaram-se as propriedades de dez mil, cem mil e até um milhão de hectares, em flagrante desobediência à Constituição de 1946, que exigia aprovação do Senado para qualquer concessão superior a dez mil hectares. As diferenças sociais se agravaram e se estenderam. (CPI, 2000, p.346).

A propriedade privada da terra na Amazônia é algo que desperta desconfiança. O Estado é o único a determinar o uso e titularidade de propriedades, não obstante, nos casos de grilagem de terras é recorrente a vinculação ao período das sesmarias. No entanto, não raro encontramos casos de títulos falsificados, conforme o apontado no relatório da comissão parlamentar de inquérito sobre as terras públicas.

A isto se deve a falta de controle do Estado sobre o território. Somado a falta de caráter de determinados agentes do poder público que auxiliaram os fraudadores a regularizarem terras devolutas. Outros elementos facilitaram as apropriações indevidas. Dentre estes os espaços, distâncias e dificuldades de comunicação que incentivaram as ilegalidades fundiárias de todo tipo. A volubilidade das políticas governamentais para a região também exerceu papel importante neste sentido (CPI DE TERRAS, 2000:569). 


\subsection{Políticas desenvolvimentistas para a Amazônia.}

No período ditatorial, a forma de desenvolvimento econômico para a Amazônia estava pautada na presença de capital estrangeiro. A retirada de recursos minerais para atender às demandas internacionais de matéria prima fez com que multinacionais passassem a investir na região. "Sob o lema integrar para não entregar, as terras da Amazônia sem homens que deveriam ser destinadas para os homens sem terra foram praticamente entregues às grandes empresas beneficiadas pela política de incentivos fiscais" (FERNANDES, 1996, p.34).

Abandonou-se, nas políticas governamentais, o padrão rio - várzea - floresta, necessário para o funcionamento estrutural ligado à economia gomífera atrelado ao modo de vida camponês, para o padrão estrada - terra firme - subsolo, referente aos interesses do grande capital. A chegada da modernização, estrada e energia, possibilitou a territorialização do capital pelos projetos minero-metalúrgicos e agropecuários (OLIVEIRA, 2009). Estes empreendimentos, entretanto, causaram destruição ambiental, desintegração social e cultural.

O processo migratório foi progressivo. Chefes de família, pessoas solteiras em geral homens conhecidos como peões do trecho, e famílias inteiras vieram de diversas partes do país em busca de melhoria, é quase um ideal a ser perseguido. É através dessa busca que estes camponeses justificam os vários deslocamentos que realizaram ao longo de suas trajetórias, seja do ponto de vista espacial, seja ocupacional (Magalhães, 2002, p.284).

Neste caso, a principal melhoria é a terra, de acordo com D'Incao (2002, p.10) no que a mesma denomina de movimento de construção social do campesinato paraense.

O palco desse movimento é o intenso processo de reorganização da sociedade paraense, em decorrência da aceleração do avanço da economia capitalista dominante no centro-sul do país em direção à região, devidamente apoiado pelas políticas dos governos militares para o desenvolvimento da Amazônia: de um lado, as chamadas "políticas de ocupação de terras" que, ao mesmo tempo em que transferiam os atores dos conflitos de terra - latentes ou manifestos - do sul para o norte do país, intensificavam o já existente processo de migração de famílias camponesas pobres, excluídas do acesso à terra fértil em regiões vizinhas, rumo às terras virgens e supostamente devolutas da Amazônia; de outro lado, os chamados "grandes projetos" (de desenvolvimento) que, ao mesmo tempo em que expulsavam as populações localizadas nas suas áreas de implantação, atraíam, com a promessa, muitas vezes enganosa, de novos empregos, grandes levas de populações excluídas ou ameaçadas de 
exclusão em outras localidades atingidas pelas mesmas políticas de desenvolvimento.

As melhorias estariam vinculadas às promessas do governo de colonização da região, atraindo milhares de famílias que ansiavam por Reforma Agrária. Dessa maneira se constituiria a mão de obra indispensável aos "grandes projetos". Resolver a questão de conflitos não era o foco do governo, como afirma Fernandes,

\begin{abstract}
Em seu encaminhamento político, os governos militares utilizaram-se da bandeira de reforma agrária, mediante projetos de colonização, na promessa de solucionar os conflitos sociais no campo, atendendo assim aos interesses do empresariado nacional e internacional. Como o objetivo era colonizar para não reformar, o problema da terra jamais seria resolvido com os projetos de colonização na Amazônia, pois o que estava por trás desse processo era uma estratégia geopolítica de exploração total dos recursos naturais pelos grandes grupos nacionais/internacionais. Assim, 0 envolvimento das Forças Armadas, do Estado autoritário garantiram aos grandes grupos econômicos a exploração da Amazônia. (FERNANDES, 1996, p.34).
\end{abstract}

Os Grandes Projetos inscreveram-se na história da Amazônia. Seja como um grande desagregador de elementos sociais, considerando os fluxos migratórios que desencadeou, seja pelos danos ambientais e saques sucessivos de recursos naturais. E o mais discrepante nesse período de efervescência nacionalista é pensar em crescimento econômico dissociado dos povos amazônicos.

Oliveira (1987) descreve as negociatas envolvendo capital estatal, privado nacional e estrangeiro. Os interesses envolvendo produção madeireira escondia o principal objetivo, tratava-se da exploração de minérios. No entanto, nada impediria de se extrair ao máximo os espaços florestados. O plano seria de implantar 12 florestas regionais de rendimento. Essas florestas somariam uma superfície total de 39 milhões de hectares, uma superfície, superior àquela ocupada pelo estado do Piauí.

Os latifúndios se estabeleceram sob a tutela do Estado, dentre eles o projeto Jari do multimilionário norte-americano Daniel Keith Ludwig. De acordo com Oliveira (1987) foi destinado, a este projeto, uma área de 3.387 .090 ha equivalente a $33.870,9 \mathrm{~km}^{2}$. Esta propriedade ocuparia uma superfície maior que os estados de Sergipe e Alagoas, maior que a soma da área ocupada por mais de 1,5 milhão de propriedades rurais no Brasil. 
Martins (1991, p.121) afirma serem os latifúndios do Nordeste minifúndios se comparados com as fazendas amazônicas. Em cálculos muito grosseiros, essa área poderia dar trabalho a um milhão de pequenos agricultores, uns 5 milhões de pessoas, se considerarmos o padrão do minifúndio brasileiro.

Deste modo, torna-se compreensível a constante migração e luta do campesinato pela terra. A busca pelo lugar de largueza (BRANDÃO, 1995, p.66), diante da situação encontrada, conduz a uma nova procura por lugares de largueza, pois a terra ali já foi apropriada pelo latifúndio.

A saída do Ceará, passando pelo Maranhão, Pará até chegar ao Amazonas é a realidade de parte dos camponeses residentes na comunidade Pau Rosa no Projeto de Assentamento Tarumã Mirim em Manaus. Este campesinato expropriado ou que nunca teve sua própria terra seguiu trabalhando em fazendas e na construção das estradas até chegar a Manaus e se instalar no referido projeto de assentamento. 


\subsection{Grupos sociais atingidos pelos grandes projetos.}

Os projetos de integração nacional para o desenvolvimento de regiões pobres como era/é considerada a região amazônica, fez desta e de seus povos "seres atrasados" passíveis de modernização. Foi negado a estes o direito de determinar o rumo de suas próprias vidas. Aos amazônidas não foi perguntado a opinião e permissão para mundializar os recursos naturais, destruir seus modos de vida, alagar suas casas, remanejar famílias inteiras.

A partir deste momento passa a ser uma preocupação ter o documento da terra, grupos que secularmente construíram seus territórios agora precisavam comprovar o seu direito de permanecer na terra, quando se negavam em sair, aí estava o Estado com todo o seu aparato para fazer cumprir a lei, em benefício do latifúndio. Para Oliveira (1987, p.14), este processo tem algozes e vítimas.

\footnotetext{
Os algozes são a fração burguesa da sociedade brasileira que sob a tutela do Estado gendarme aliou-se internacionalmente, internacionalizando-se, e assim mundializando a economia brasileira. As vítimas são, de uma forma geral, os trabalhadores e, em particular, os posseiros, os garimpeiros, os seringueiros, os coletores de castanha, os colonos e, por fim, as nações indígenas.
}

A região amazônica tornou-se alvo de discursos com vistas à internacionalização, levando-a a ser considerada como patrimônio natural da humanidade e, portanto, sua maior parte não poderia ficar sob o domínio de um único país (ARBEX JR, 2005 p.27). Tais imposições determinam a condição de subalternidade a que está secularmente submetida, isto implica na visão que se tem da região, Gonçalves (2010) descreve a imagem estereotipada relacionada com uma visão mais sobre a região do que da região, assim os amazônidas sofrem os efeitos do colonialismo.

Neste contexto, a cultura local é encarada com preconceito, visto o modo de vida do camponês amazônico ser diferente do campesinato que se estabeleceu na frente de expansão amazônica. A população local é considerada como incapaz de produzir alimentos e fazer grandes construções, portanto, para Gonçalves (2010, p.12) a população "é vista como indolente e preguiçosa [...] estaria a região, de um modo ou de outro, condenada pelo passado". 
As perspectivas que menosprezam os grupos que habitam a Amazônia foram e são tão eficientes a ponto de se difundirem entre os considerados "de fora" e mesmo pelos amazônidas. Não à toa que os "grandes projetos" foram pensados para "desenvolver uma região com grande potencial", mas sem pessoas qualificadas para gerenciá-lo.

Com relação às questões sociais, diversos segmentos que ao se organizarem em torno da luta pela terra e contra a expropriação, se transformaram em movimentos sociais. Em seu estudo, Grzybowski (1991, p.18) busca salientar a diversidade existente neste cenário, classificando o movimento em quatro grupos, os de Posseiros, Sem terra, Barragens e Indígena. No entanto, é preciso ressaltar que no estudo do referido autor não são consideradas todas as situações de luta pela terra, mas só as que configuram um movimento.

Nota-se que os mais atingidos pela territorialização do capital são aqueles cujo modo de vida depende em maior grau do acesso a terra e à produção agrícola, ou seja, ao campesinato despojado, em geral violentamente, de suas terras. Segundo Oliveira (2002, p.43) entre 1984 e 1989 várias regiões concentraram conflitos, especialmente a região do Bico do Papagaio, que junto com as regiões Sudeste do Pará, Bragantina e Pindaré-Mearim no Maranhão, formam a principal área com registro de assassinatos no campo.

Apesar de estar comprovado que a maior parte dos gêneros alimentícios é proveniente das unidades camponesas, visto a grande propriedade não ter interesse na produção de alimentos para o mercado interno, justamente a chamada "lavoura de pobre" (MARTINS, 1991), o governo privilegia com incentivos subsidiados a grande propriedade. Enquanto isso, os números de mortos em conflitos pela terra continuam crescentes. Nestes termos, parece distante a solução para se resolver os conflitos agrários na região.

Para José de Souza Martins (1991, p.76) o crescimento das tensões sociais na Amazônia deve-se à natureza dos movimentos populacionais provenientes da concentração fundiária no Brasil.

Ariovaldo Umbelino de Oliveira contribuiu com estudos sobre o processo de expropriação dos posseiros e índios na Amazônia,

O projeto de implantação/expropriação dos projetos agropecuários na Amazônia, fazia parte das conclusões obtidas após o chamamento do governo militar de Castelo Branco aos grupos econômicos 
nacionais/internacionais e que se consubstanciou na "Operação Amazônia. [...] esses empresários investiram nesta empreitada da ocupação da Amazônia pela pata do boi, sendo o resultado, no mínimo melancólico. Pois o rastro deixado por este processo é quase sempre marcado pelo sangue. Sangue derramado das nações indígenas e dos posseiros. Sangue derramado dos peões no trabalho de "abertura da mata". (OLIVEIRA, 1987, p.68).

Passados 42 anos da implantação dos grandes projetos a violência registrada contra os amazônidas a cada ano estabelece recordes. Gonçalves, analisando os dados da CPT coletados em 2011 registrou o maior índice de violência desde quando a série começou a ser sistematizada em 1985 e a Amazônia,

[...] destaca-se como a região onde é mais intensa a violência do poder privado, com uma participação de $52,2 \%$ do total das ações dos Fazendeiros em todo o país; $67,7 \%$ do total das ações violentas dos Empresários; $86,6 \%$ das ações dos Grileiros; $96,8 \%$ das ações dos Madeireiros; $65,1 \%$ das ações das Mineradoras e $80 \%$ das ações dos Pistoleiros. Esses números dão conta da expansão violentíssima sobre a Amazônia do complexo de violência e devastação protagonizado pelo poder privado, onde se destacam não só os tradicionais protagonistas como os Grileiros, os Madeireiros e os Pistoleiros, mas também protagonistas que se apresentam com nova roupagem, como a de Empresários, inclusive de Mineradoras, e que são surpreendidos com as mesmas e tradicionais práticas de violência! A violência moderno-colonial continua nos atingido. (GONÇALVES, 2012, p.79).

Fica evidente na "nova roupagem" das multinacionais, o caráter supostamente ambiental e sustentável da sua existência na Amazônia. Técnicos do poder público chegaram a afirmar que a mineração era a atividade recomendada para a Amazônia por desencadear impactos ambientais setorizados se comparados com projetos de exploração madeireira (OLIVEIRA, 1987). 


\subsection{Reconfiguração camponesa na Amazônia.}

Diante das condições adversas promovidas pelo Estado em função de interesses individuais restou ao campesinato lutar para permanecer na terra ou migrar novamente, atuando como alargador da frente de expansão (MARTINS, 1991, p.67).

A resistência se tornou um dos elementos presentes na fronteira. Isto se explica pelo nível de expropriação se tornar insustentável, visto que as políticas de incentivos fiscais estimularem o interesse da grande empresa pela terra. Martins (1991, p.31), esclarece "[...] se a condição para receber o incentivo é ocupar a terra, então vamos ocupar. Entra em terra de índio, em terra demarcada, entra no que der! E tem que expulsar o pessoal violentamente, o que acaba produzindo reações".

Para os indígenas foram demarcadas terras, em alguns casos, foram realocados para locais diferentes dos que ancestralmente estavam ligados. Como ocorreu com os Parakanã que foram deslocados para uma área próxima onde foi construída a barragem de Tucuruí no Pará, sendo deslocados mais uma vez (MARTINS, 1991).

No caso dos Waimiri Atroari e posseiros residentes na área adjacente a usina hidroelétrica de Balbina no município de Presidente Figueiredo-AM, distante 107 quilômetros de Manaus, nas proximidades da BR 174, o resultado foi diferente. Lá a resistência atingiu níveis extremos de violência, os dois povos indígenas, Waimiri e Atroari, foram praticamente dizimados, foram mortos posseiros, engenheiros, antropólogos (MARTINS, 1991; OLIVEIRA, 1987).

A situação do campesinato não foi diferente. Às famílias recém-chegadas se depararam com a possibilidade de reconstruir suas vidas para, em seguida, serem expulsas e mais uma vez ir à busca de mais um pedaço de terra.

O problema referente aos conflitos pela terra não é exclusividade da Amazônia. Mas, foi a Amazônia o destino da maior parte dos expropriados pela concentração fundiária, violência e dos deserdados da terra ${ }^{1}$ (MOURA, 1978). Isto ocorre porque o fracionamento da terra chega a um ponto extremo de impedir a reprodução da família camponesa, característicos da região Centro-Sul e do

\footnotetext{
${ }^{1}$ A impossibilidade de todos os membros de uma mesma família ter acesso a terra, força os demais a procurarem terras noutros estados. A Amazônia tornou-se destino para muitos dos deserdados por costumes familiares.
} 
Nordeste, onde predominaram relações de latifúndio-minifúndio (GRZYBOWSKI, 1991).

A venda da terra no Sul e Sudeste abre possibilidades de se comprar terra em maior quantidade na Amazônia. O capital subordina a produção camponesa e expropria lentamente as famílias de suas terras, como observou Martins (1991, p.9192),

\begin{abstract}
[...] Embora o colono não esteja sofrendo uma expropriação direta, está de fato sendo expropriado das condições de reprodução ampliada da sua condição social de pequeno produtor autônomo. O capital que indiretamente subjuga o seu trabalho através da mercadoria fecha-lhe o caminho do futuro. Se antes, décadas atrás, o imigrante e colono estava sitiado institucionalmente pela grande lavoura, hoje está sitiado pelo grande capital. Seus filhos e netos retomam o caminho da estrada. Matula nas costas, como seus antepassados de um século atrás, vão saindo aos grupos do Rio Grande, de Santa Catarina, do Paraná, no rumo da Amazônia Ocidental, para recomeçar num espaço novo as velhas tradições da produção familiar, para reconstituir lá longe, na terra virgem, o modo de vida que fora contaminado pelo capital nas terras já cansadas do Sul. Muitas vezes o próprio capital abre a porteira de acesso à estrada do Norte, comprando os pequenos lotes e vendendo na mata distante lotes mais extensos, para mais um século de trabalho familiar autônomo.
\end{abstract}

Diante do exposto, só é possível compreender os conflitos pela terra na Amazônia se relacionarmos a uma escala mais ampla. Os fluxos migratórios advindos do país inteiro têm, em sua origem, as causas mais diversas. A Amazônia funcionou como "zona de amortecimento" dos conflitos. Mas, as terras livres, comumente designadas, não eram a solução do problema da concentração fundiária no país (MARTINS, 1995, 1991; OLIVEIRA, 2005, 1987). 


\subsection{A questão agrária no Amazonas}

A geografia agrária do Amazonas difere substancialmente dos demais estados da região. A forma como o capital se territorializou no estado foi menos violenta do que o do vizinho estado do Pará, e passou a ser o destino das famílias camponesas expropriadas das áreas de conflito. Destes, a maior parte são unidades de conservação e terras indígenas (mapa 1). Isto é, deveriam ser preservados.

No Amazonas a monopolização do território realizou-se primordialmente com a introdução dos projetos agropecuários, principalmente os madeireiros. Enquanto em estados como Rondônia, Pará e Amapá predominaram os projetos minerometalúrgicos. Após o recebimento dos incentivos fiscais e a retirada da madeira as áreas foram abandonadas e posteriormente ocupadas por posseiros. Os camponeses permanecem nessas áreas sem infraestrutura básica e não podem se tornar os proprietários do lote por causa da dívida feita pelos primeiros beneficiários, os “empresários paulistas" (OLIVEIRA, 2005, 1987).

De acordo com Neves (2011), a Amazônia possui aproximadamente 600 mil ribeirinhos e o estado do Amazonas 300 mil, estando passíveis de regularização fundiária. A área de várzea supera os $300.000 \mathrm{~km}^{2}$ (SURGIK, 2005, p.15). O impasse apresentado é relativo à legislação de uso das áreas de várzea. Por se tratar de áreas de alagação anual nas margens dos rios não poderia haver tal regularização por ser área da marinha brasileira.

Para Benatti (2005) outro empecilho se refere à restrição de uso dos espaços. Caso se defina a delimitação da propriedade, os ribeirinhos não poderiam mais fazer uso das áreas de terra firme. Os ribeirinhos fazem suas roças na várzea e na terra firme realizam a coleta, caça, extração de madeira para construir casas. Neste sentido, a regularização da propriedade na várzea impediria o uso da terra firme e vice-versa.

No mapa 1 - Nas áreas protegidas do Estado do Amazonas observa-se a presença de unidades de conservação municipal, estadual e federal, Terras indígenas demarcadas e em estudo. Há dois eixos de áreas protegidas, a Norte estão próximas às fronteiras internacionais da Venezuela e Colômbia e na divisa com Roraima. Enquanto na porção Sul contornam a divisa dos estados de Mato Grosso e Rondônia. Estendendo-se por uma larga faixa no entorno da BR 319 Manaus - Porto Velho. 
Mapa 1 - Áreas Protegidas do estado do Amazonas.

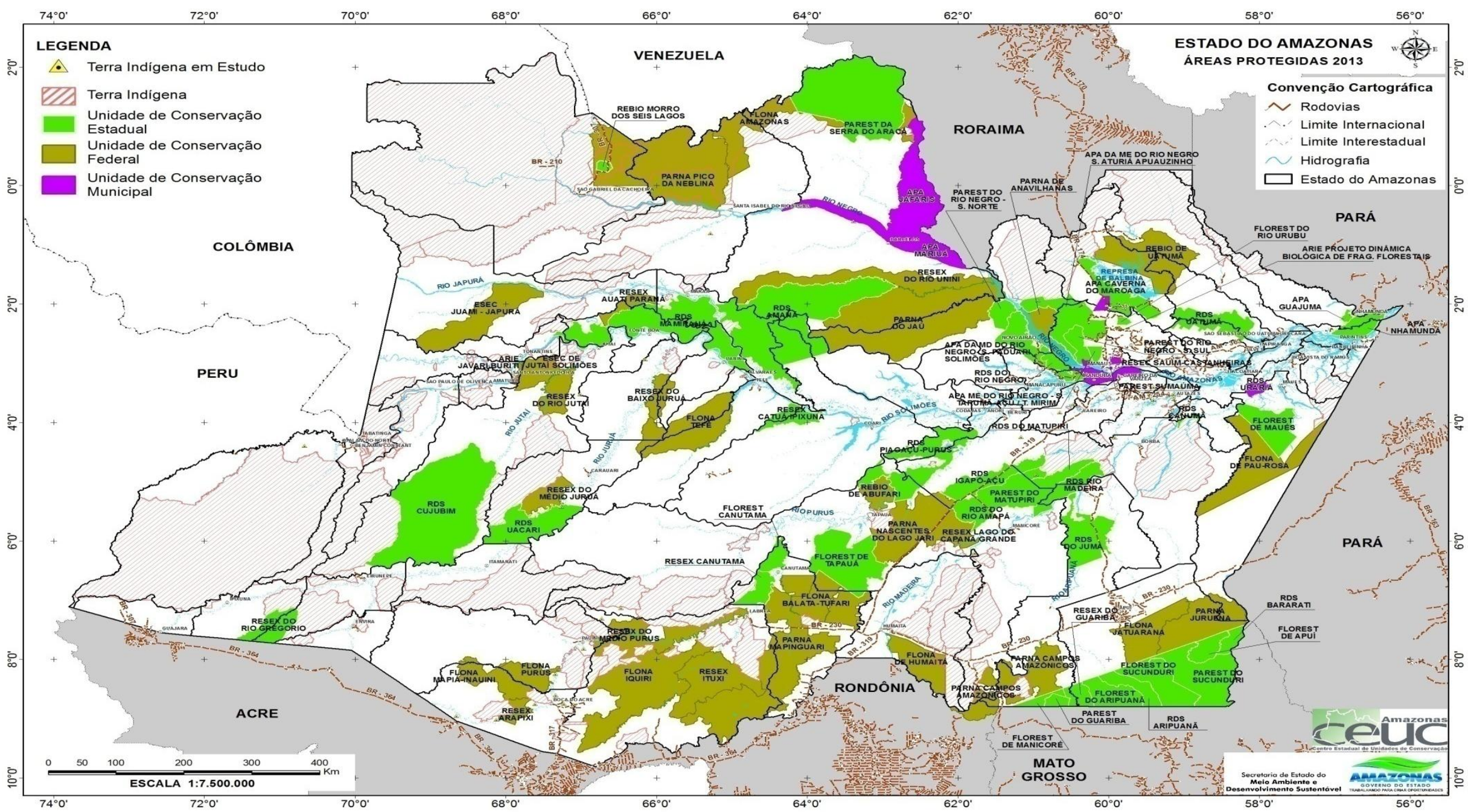

Fonte: IPAAM, 2013. 
Nos casos de áreas protegidas de proteção integral, estas se tornam um impedimento para o uso dos elementos da natureza pelos povos amazônicos, que há gerações utilizam a mata para a caça, coleta, extração, pesca e formação de roça. Arruda (2000, p.280) explica esta situação,

\begin{abstract}
Quando resistem e permanecem, suas necessidades de exploração dos recursos naturais inerentes a seu modo de vida e sobrevivência raramente são reconhecidas. Em vez disso, passa a ocorrer uma "criminalização" dos atos corriqueiros e fundamentais para a reprodução sociocultural destas comunidades. A caça, a pesca, a utilização de recursos da floresta para a manufatura de utensílios e equipamentos diversos, a feitura das roças, a criação de galinhas ou porcos, o papagaio na varanda, a lenha para cozinhar e aquecer, a construção de uma nova casa para o filho que casou, etc., tudo isso é, de uma penada jurídica, transformado em crime e seus praticantes perseguidos e penalizados. Ao mesmo tempo, são instados a proteger e respeitar o meio ambiente, sendo encarados como os principais responsáveis (e não o modelo urbano-industrial em expansão) pelo futuro da humanidade, corporificado na preservação da área em questão.
\end{abstract}

A lógica cartesiana de delimitação de unidades florestadas, empreendida pelo Estado, determina normas de uso interferindo na reprodução do modo de vida camponês e na mesma proporção não inibe o desmatamento. Para Tavares (2012) o desmatamento representa o fim da disputa, não só porque propicia a formação das pastagens para a fazenda, mas por causa da destruição dos elementos fundamentais do modo de vida, ligado a existência das florestas.

Aos povos amazônicos é negado o direito de uso da natureza, enquanto isso, não raro encontra-se casos de serrarias em Unidades de Conservação e Terras Indígenas, barcos de pesca industrial retirando grande quantidade de peixe em período de defeso em lagos e rios, em certos casos, pertencentes a alguma área protegida (CPI, 2001). A grilagem promove o desmatamento para a venda de madeira, e em seguida, implantar a agropecuária,

[...] Ao assumir a terra pública, os novos detentores empenham-se em desocupá-la, expulsando seus moradores. Os que resistem o fazem de forma desigual, pois enfrentam grupos economicamente fortes, os quais recebem tratamento privilegiado do Estado, são resguardados por uma legislação discriminatória e por acordos políticos, além de possuírem influência sobre o poder Legislativo e Judiciário. (TAVARES, 2012, p.18)

Além das expropriações de terras, como já assinalado, outro elemento também contribuiu fortemente para o movimento migratório para o Amazonas e 
principalmente para Manaus, a implantação da Zona Franca de Manaus (ZFM), a qual Oliveira (1987, p.111) denominou de "Hong Kong brasileira".

O projeto ZFM, criado em 1967 deveria auxiliar no desenvolvimento econômico do estado. As multinacionais se estabeleceriam em todo o estado, recebendo incentivos fiscais, num primeiro momento, até que pudessem ser autossuficientes, como forma de impulsionar a formação de um pólo industrial nacional e agropecuário, segundo Oliveira (1987, p.112, 113),

[...] O aspecto principal da Zona Franca de Manaus é o de que as empresas se aproveitam da isenção de impostos para produzirem, utilizando-se de mão de obra barata, para o mercado internacional, com forte capacidade de competição e com lucros altíssimos. À Amazônia e ao país fica muito pouco, para não dizer quase nada. [...] É dessa forma que foi gestada esta outra faceta da internacionalização do produto do trabalho dos trabalhadores de Manaus. Este processo garante o acesso das multinacionais à Amazônia sem que a mesma tivesse, que ser transformada em território internacional sob o controle de outro governo. Os próprios governos militares do país incumbiram-se de promover esta internacionalização econômica da Amazônia, consentânea com esta etapa monopolista do desenvolvimento do capitalismo internacional.

A SUFRAMA (Superintendência da Zona Franca de Manaus) é uma autarquia federal que administra a ZFM e se tornou detentora de terras, de modo a elaborar e aprovar projetos agropecuários destinados ao campesinato local e migrante. Essa autarquia de gestão industrial recebeu terras e passou a determinar projetos em terras públicas. São as DAS (Distrito Agropecuário da SUFRAMA).

No entanto, a ZFM se tornou uma "área de montagem" de peças vindas do exterior, sobretudo da China, Coréia do Sul e Japão. O impacto fundamental da implantação da Zona Franca foi o crescimento da cidade de Manaus, e sua atuação não se estendeu a todo o estado como estava previsto, o pólo industrial e a maior parte dos migrantes ficaram concentrados na capital. Ab' Sáber assim retratou este processo,

O crescimento populacional de Manaus reflete diretamente a instalação do distrito industrial da Suframa e o rápido e quase contínuo desenvolvimento comercial da Zona Franca. [...] Em 1970, nos primórdios de instalação da Zona Franca, a cidade deu um salto demográfico, atingindo 281.685 habitantes. E, daí para a frente, tornou-se uma cidade grande, registrando $611.763 \mathrm{em} 1980$ e atingindo pouco mais de um milhão de pessoas em 1991 (1.009 774). O mecanismo de produção de espaços urbanos na região do baixo planalto de Manaus foi relativamente complexo, já que comportou inicialmente um modelo de crescimento de bairros carentes em posição intra-urbana segundo a tradição das "invasões" ao longo dos igarapés e, 
logo depois, uma periferização semi-ordenada, pelos quadrantes interiores. [...] Com o crescimento demográfico e o forte e complicado desdobramento do espaço urbano, a cidade acentuou as disparidades sociais, assistindo ao adensamento da pobreza intra-urbana e ao advento de focos de violência, aparecimento de comércio informal e subemprego. $O$ crescimento demográfico, realizado basicamente por fortes correntes migratórias de todos os quadrantes da Amazônia Ocidental, Solimões e Médio Amazonas, deveu-se às ações múltiplas de criação de mercado de trabalho formal ou informal, precipitado pela implantação do distrito industrial da Suframa e da Zona Franca (ZFM). (AB'SÁBER, 2004, p.220-222).

A pobreza intensificada após a instalação da Zona Franca, é atribuída em grande parte, ao êxodo rural, originário dos municípios do interior do estado, visto a falta de planejamento urbano ser indiferente ao crescimento populacional (AB'SÁBER, 2004). Nestes termos, o município de Manaus passou a ser ocupado por posseiros tanto na cidade quanto na área rural.

É interessante notar que na chamada zona rural de Manaus ocupada por posseiros foram criados projetos de assentamento. Nesta situação está o projeto de assentamento Tarumã Mirim, distante da cidade $21 \mathrm{~km}$ na BR 174, Manaus - Boa Vista. Quem já ocupava a área no entorno da BR e mesmo do que veio a ser a comunidade Pau Rosa teve a opção de ser assentado. No entanto, o Estado não ofereceu a infraestrutura adequada para que os camponeses assentados pudessem desenvolver plenamente suas atividades. 


\title{
CAPÍTULO 2 - A ASSOCIAÇÃO COMUNITÁRIA PAU ROSA.
}

A comunidade Pau Rosa é uma das dezesseis comunidades integrantes do $P$. A. Tarumã Mirim. O termo comunidade aqui empregado faz referência à divisão político administrativa do assentamento feita pelo INCRA, visto ser o quarto maior do amazonas em quantidade de parcelas, 1.079 ao todo.

Participar de uma comunidade rural também implica o sentido de uma unidade, pertencimento, partilhar de projetos ou problemas em comum (DICIONÁRIO DA TERRA, 2005, p.112),

\begin{abstract}
[...] trata-se de indicar um grupo concreto delimitado em termos territoriais (a população de uma localidade, distrito, município) e em termos de sua atividade (pessoas que se ocupam de atividades "rurais", ligadas à agricultura e à pecuária), mas, ao mesmo tempo, a expressão sugere que esse grupo que se organiza a partir de relações de proximidade e solidariedade, em que se sobressaem a importância do parentesco, vizinhança, cooperação no trabalho, co-participação nas atividades lúdicoreligiosas, apontando para valores de harmonia e consenso.
\end{abstract}

A área em que atualmente está a comunidade Pau Rosa foi sendo ocupada por famílias de posseiros desde a década de 1970. Quando camponeses se embrenhavam na mata nas proximidades da BR 174 (Manaus - Boa Vista) para marcar os seus sítios estavam acompanhados por parentes. Ao efetivar o assentamento ficaram com os lotes próximos intensificando a relação em comunidade.

O nome do ramal "deve-se a atuação de uma usina de exploração do óleo de Pau Rosa, madeira abundante na região nas décadas de 60 e 70. Com a extinção das espécies na região a usina foi desativada" (CARVALHO, 2010, p.134). Dessa espécie é extraído o linalol, que faz parte do bouquet de perfumes da indústria francesa, dentre eles o Chanel No. 5. (LEITE et al, 1999, p. 6)

Possui cinco estradas vicinais, conforme mapa 2. São elas: Prosperidade, Dantas, Cristo Rei, Diamante do Norte e o ramal principal Pau Rosa, este possui 27 $\mathrm{km}$, sendo o único asfaltado. Dentre estas vicinais, a que designa na nomenclatura o caráter familiar é a vicinal Dantas. De acordo com os assentados, era chamada de vicinal dos Dantas porque seis lotes dessa vicinal pertenciam a esta família.

Os nomes atribuídos pelos camponeses para as vicinais são repletos de simbolismos, retrata-se a esperança num futuro melhor, conviçcões religiosas, 
familiares, a 'riqueza' atribuída ao lugar da terra própria. As características desta comunidade camponesa no Amazonas são semelhantes às encontradas por Hébette, Alves e Quintela (2002, p.186).

[...] fala-se de "comunidades" às quais os habitantes atribuíram nomes significativos para eles: Boa Esperança ou Nova Esperança, Santa Maria, Sítio Novo, Pau Seco, Céu Azul, Nova Jerusalém. Essas denominações, de conotação frequentemente religiosa, refletem a nostalgia dos lugares de origem, tanto quanto o sentimento de uma vida nova e a fé em um futuro melhor.

Em trabalhos de campo à comunidade São Sebastião, extremo Sul do assentamento, foi relatado que esta comunidade deveria ser a principal, por ter a sua sede no igarapé Tarumã Mirim, considerando as características amazônicas na qual os rios são os principais meios de transporte, assim enfatizado por Tocantins (1961, p.251),

O homem e o rio são os dois mais ativos agentes da Geografia humana da Amazônia. $O$ rio enchendo a vida do homem de motivações psicológicas, o rio imprimindo à sociedade rumos e tendências, criando tipos característicos na vida regional.

Com as melhorias na rodovia BR-174 (Manaus - Boa Vista) houve uma transferência da centralidade para a comunidade Pau Rosa, enquanto, a comunidade São Sebastião passou a ter uma posição secundária na destinação de infraestrutura do assentamento.

A numeração das parcelas evidencia a ideia de que o transporte principal seria via igarapés. Inicia-se essa contagem na comunidade São Sebastião, enquanto na comunidade Pau Rosa os lotes apresentam numerações altas (ver Anexo B).

O acesso para São Sebastião é pelo igarapé Tarumã Mirim, com o tempo em média de trinta minutos de barco da marina do Davi ${ }^{2}$. Outra forma de se chegar é pelo ramal da Cooperativa, demorando cerca de duas horas do entroncamento com o ramal Pau Rosa. No entanto, segundo o presidente da comunidade São

\footnotetext{
${ }^{2}$ Porto localizado no rio Negro, bairro da Ponta Negra onde embarcações de pequeno e médio porte fazem o transporte de passageiros para as comunidades ribeirinhas do Rio Negro e igarapé Tarumã Mirim.
} 
Sebastião, o Sr. Josimar Peixoto, "quando chegou a infraestrutura no PA Tarumã o presidente da época não teve peito pra trazê as coisa pra cá e ficou por lá pelo Pau Rosa".

Tal afirmação revela o jogo de forças no interior do assentamento. Quem teve "peito" (força política) conseguiu levar a infraestrutura para sua comunidade. São Sebastião deveria exercer uma centralidade no assentamento, como a concentração da infraestrutura básica de educação e saúde. A escola e o posto de saúde foram construídos na comunidade Pau Rosa. Na verdade, esta infraestrutura deveria existir em todas as comunidades.

De acordo com o ex-presidente da comunidade Pau Rosa, o Sr. Narlon da Silva, estava previsto a construção de uma infraestrutura urbana na sede da comunidade que incluía um hotel de selva como incentivo ao turismo rural. Esta sede se situa no km 21 do ramal Pau Rosa, onde funciona a escola Neusa dos Santos Ribeiro, o posto de saúde e a associação de moradores. 
Mapa 2 - Associação Comunitária Pau Rosa.

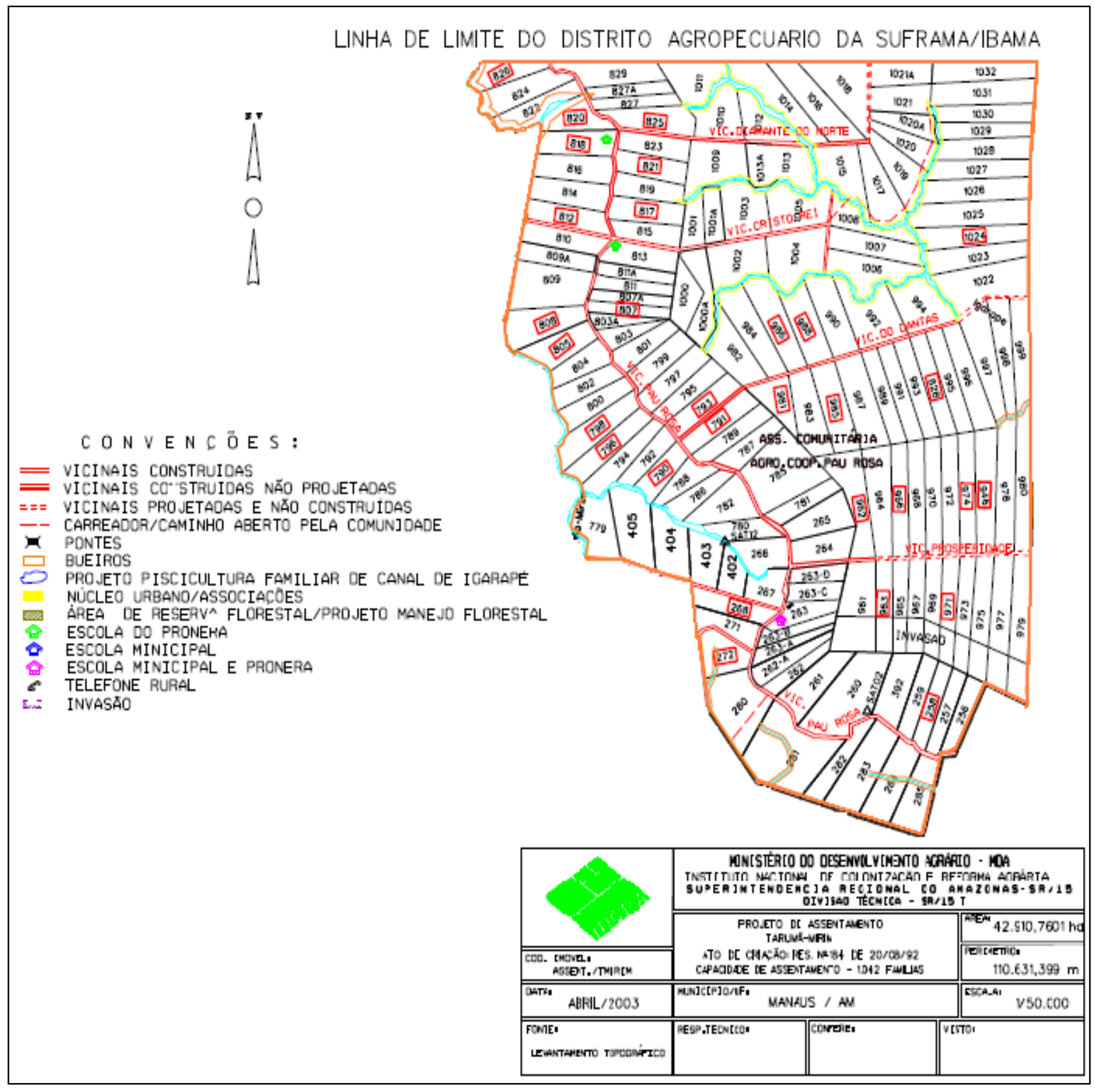

Fonte: INCRA (2011). 
Segundo a atual presidente da associação Pau Rosa, o Sr. Claudionor, o principal problema vivido pelos comunitários é o suporte técnico.

Aqui a gente vive bem, deu uma melhorada boa, [...] o nosso maior problema aqui é a assistência técnica, já vi agricultô pegá dinheiro do fomento e duma hora pra outra chegá aquele monte de pintinho e não tê o galinhero pronto, daí o pessoal do IDAM entrega os pintinho e o agricultô tem que se virá. Porquê num vem um técnico primeiro e aí diz, faz o galinhero que os pinto vai chegá tal dia. E num é assim, aí as galinha põe ovo no mato e não adianta nada. A gente aqui, falando no geral, tamo bem, agora, tá feio é pra quem tá lá no ramal da usina, eles não tem apoio de nada, é só Deus por eles.

A fala retrata o reconhecimento de que as melhorias, apesar de tanto tempo, chegaram; até mesmo o asfalto, que para os camponeses "é coisa da cidade". Mas, as parcerias entre SEPROR/IDAM, INCRA, Prefeitura de Manaus, ainda são deficientes. A SEPROR é responsável pelos insumos, o IDAM pelos técnicos agronômicos, o INCRA auxilia na elaboração dos projetos e na documentação e a prefeitura de Manaus possui maquinários como tratores, caçambas, caminhonetes.

É notável a solidariedade pelos agricultores assentados e os posseiros, que mesmo não pertencendo ao assentamento, constituem-se como membros da mesma luta, a terra para plantar e viver dos seus frutos. Martins (1995, p.131) explica esse processo assinalando se tratar de uma luta pelo trabalho e não necessariamente pela terra, "a noção de posse é uma noção que privilegia não a terra, mas o trabalho: a terra entra como instrumento do trabalho, como mediador do trabalho". Esta dimensão do trabalho está presente na reflexão de Bombardi (2004, p.77),

\footnotetext{
Os camponeses possuem uma forma de ver a terra que a princípio não passa pela propriedade, passa antes por uma questão moral que está no âmbito da justiça: um ser humano não pode ser privado do trabalho, e, portanto, de viver, enquanto há terras desocupadas; assim como não pode ser expulso da terra em que trabalha mesmo que esta tenha título de propriedade, pois o título pode ser legal, mas não legítimo, já que muitas vezes é adquirido de forma ilegal e injusta.
}

Noutra obra Martins (1991, p.25) expõe, "o posseiro luta pelo trabalho de sua família, mas ele não luta pela propriedade, coisas que são completamente distintas". Prova disso, os posseiros do ramal Pau Rosa não se mobilizaram, antes do conflito com o IBAMA, e por extensão a CEULM/ULBRA, para delimitação de parcelas. No 
estabelecimento do conflito e contra a expulsão, surge a necessidade de determinação da propriedade.

Neste caso, os posseiros se encontram em situação de desvantagem, considerando que o Estado privilegia as classes dominantes. Portanto, as terras públicas, passíveis de ocupação para a Reforma Agrária são designadas para o interesse do capital privado.

José Barbosa de Carvalho $^{3}$ (2010) descreve a situação conflituosa e de descaso com os posseiros estabelecidos na área da antiga usina de Pau Rosa. A área pertencia à SUFRAMA, fazia parte da DAS (Distrito Agropecuário da Suframa) sendo repassada ao IBAMA em 1981. O IBAMA, por sua vez, não desenvolveu nenhum projeto e em 1992 posseiros ocuparam o local.

Estes camponeses posseiros passaram, portanto, a formar seus cultivos, construíram casas, açudes. Carvalho (2010) enfatiza que todas essas atividades e investimentos contaram com a "permissividade" do IBAMA, que "conviviam pacificamente" com os posseiros. Não à toa, em 1999 o IBAMA chegou a ministrar curso de exploração sustentável da floresta.

No entanto, em 2003, o IBAMA fez uma concessão destas terras públicas para a instituição de ensino privado CEULM/ULBRA (Centro Universitário Luterano de Manaus/Universidade Luterana do Brasil). Conforme ratificou Barbosa (2010, p.135),

\begin{abstract}
Dentre os objetivos da Ulbra naquela região estavam a realização de estudos faunísticos na área, criação de um curso de especialização em gestão de unidades de proteção ambiental, desenvolvimento de um plano de estudos que possibilitasse o uso da área de forma sustentável e construção da sede do Centro de Triagem de Animais Silvestres (CTAS). A permanência das 150 famílias de posseiros passou a ser encarada como um empecilho aos trabalhos da Ulbra e forçou o IBAMA-AM a entrar em conflito com os posseiros do ramal Pau Rosa.
\end{abstract}

Os posseiros se mobilizaram e passaram a se reunir em busca de evitar o despejo após terem constituído suas vidas. O trabalho na terra era o principal motivo da luta, de acordo com o convite para uma das reuniões, assinalada por Carvalho (2010, p.138),

\footnotetext{
${ }^{3}$ No dia da publicação da obra do referido autor, sua casa foi incendiada e seus pertences furtados. Em entrevista realizada em 22/07/2011, relatou se tratar de represálias por "mexer com assuntos perigosos e pessoas poderosas". Afirmou ter sido alertado sobre o risco de retratar esse tipo de assunto. No ano seguinte, o diretor responsável pela editora foi demitido.
} 
[...] Vamos debater o nosso destino diante das pretensões do Ibama-AM de limpar esta grande área pública, de 14 mil hectares, expulsar todas as famílias e entregá-la a uma escola particular denominada Ceulm-Ulbra, que é o Centro Educacional e Universitário Luterano de Manaus... O Incra e a Suframa estão nos ofertando terras em outras localidades, muitas delas sem a mínima infra-estrutura, sem nenhuma indenização! Vamos deixar tudo para trás, cerca de três, seis, oito e até doze anos de trabalho e sacrifício, como quer o Ibama? O que vai acontecer com as nossas plantações, nossas casas e criações?.

Os camponeses posseiros desta localidade não tem acesso às políticas agrícolas do governo estadual por conta da indefinição da situação dos posseiros. Esta área não foi integrada ao assentamento apesar da pressão e do apoio dos camponeses assentados.

Em trabalho de campo, a feira da agricultura orgânica no Ministério da Agricultura (MAPA) em Manaus, me foi apresentada, pelos camponeses da associação Pau Rosa, um camponês posseiro residente no DAS (Distrito Agropecuário da Suframa), próximo a cidade de Presidente Figueiredo, distante $107 \mathrm{~km}$ ao norte de Manaus,

Sr. C. L.: Tem gente que reclama mais tem gente que tá pió que nóis lá no Pau Rosa. Tá aí o seu A. ele é lá da SUFRAMA (DAS), eles lá nem tem esperança de regularizá a situação, lá é só Deus por eles. $A$ SUFRAMA enrola pra regularizá e eles não tem como fazê financiamento, pegá recurso pra fazê a casa, não pode mexer com nada que precisa do documento da terra, fala aí como que vocês faz lá pra viver.

Sr. A. T.: é verdade, a gente lá não recebe uma semente, nada, e o tanto que nóis já lutemo pra regularizá, aí o que a SUFRAMA diz pra gente é que como os que ganharo primeiro, lá na década de 70 pegaro tudo que podia de financiamento, a terra ficô com a dívida e ainda são os dono, a gente que trabaia na terra sempre trabaiô num pode sê dono. Lá tem de todo caso, cantor, ator, ex-muié de candidato, só gente grande, pegaro terra, vendero a madeira, tudo o que dava pra tirá lucro. Depois de sugá té o último, aí abandonaro a terra. Tem gente que era dono sem nunca tê pisado lá, os paulista, só dá as orde lá de São Paulo. Aí se a sinhora for lá, vai vê o tanto de terra desmatada e abandonada, foi aí que nóis entremo e nos tronco e barranco vamo tocando o que dá. As terra lá no DAS nem são boa como lá em Autaz (Autazes-AM). Lá o povo diz que é as milhó terra que tem por aqui perto de Manaus.

As feiras, além de serem os lugares de mercado onde ocorrem as vendas da produção agrícola, são também os espaços de socialização das notícias e compartilhamento dos problemas. Os posseiros residentes nos DAS recebem o 
apoio dos que atualmente são assentados, mas, em algum momento já foram posseiros e por isso entendem as reivindicações dos "companheiros".

O termo companheiro é largamente utilizado por causa da simpatia dos líderes das associações de agricultores com integrantes da política local do PT (Partido dos Trabalhadores) e o PC do B (Partido Comunista do Brasil), apesar das divergências entre os camponeses acerca da condução da política nacional.

Falar das dificuldades dos companheiros, mesmo que não sejam da mesma localidade é expor os problemas de uma classe. Os relatos de abandono, morosidade ou a falta de regularização dos lotes e infraestrutura precária vivida por camponeses posseiros retratam a mesma luta e o sentimento de partilhar do mesmo problema.

As questões enfrentadas pelos camponeses no ramal da usina também se repetem em outros lugares, é o caso dos Distritos Agropecuários da SUFRAMA. Os beneficiários dos lotes receberam os recursos financeiros, realizaram a exploração madeireira e não implementaram os ditos projetos agropecuários.

Os camponeses entrevistados fazem referência de pessoas, ligadas à elite econômica nacional como beneficiários do projeto. Estas pessoas são designadas como "os paulistas", tratam-se, no entanto, da figura de um "empresário/empresa" com capital suficiente para "comprar terras" na Amazônia, podendo não ser oriundo de São Paulo e por meio de influência política "ganha" terras, reproduz capital, enquanto para o camponês, adquirir terras é, em geral, um processo conturbado, permeado de conflitos. A CPI de terras (2001, p.59) cita algumas famílias,

Entre os proprietários estão os nomes de famílias consideradas tradicionais
tanto na política quanto na economia de $S$. Paulo, como a de Antônio Fleury
de Carvalho, Monteiro de Carvalho, Toledo P. Ferraz, Paes de Almeida,
Piva, Vergueiros e Costa Lima, José Kalil Filho, Celina Aparecida Casa
Grande Telles, Walter e Irene Lot Papa, entre outros. A titulação dos 155
lotes para empresários paulistas prejudicou diretamente 3 mil famílias
residentes em várias comunidades localizadas nessas áreas, que dão
margem à BR-174. São famílias de agricultores que estão impedidas de ter
acesso a crédito agrícola por não terem o título definitivo, apesar de
morarem lá há mais de uma década.

O campesinato luta pela terra de trabalho e a resistência surge quando o trabalho territorializado é ameaçado pela expulsão. Neste caso, não é qualquer trabalho, o trabalho agrícola depende da natureza, de um tempo específico. 
Qualquer indenização sugerida é incapaz de substituir o trabalho materializado numa determinada área.

É por compreender a luta pela permanência na terra que os camponeses da comunidade Pau Rosa aderiram a campanha de anexar a área em litígio, ramal da usina, ao PA Tarumã Mirim. Como parte da comunidade Pau Rosa. Por isso, os posseiros do "ramal da usina" se identificam como associados a essa comunidade. 
2.10 P. A. Tarumã Mirim, um assentamento entre rias fluviais.

De acordo com o INCRA (2011), por meio do SIPRA ${ }^{4}$ (Sistema de Informações de Projetos de Reforma Agrária), no estado do Amazonas, existem atualmente 142 projetos de assentamento (ver Anexo C), divididos em "projetos de assentamento tradicionais" na qual o beneficiário recebe o título de propriedade e os "novos modelos de assentamento" com base na concessão de uso,

- 2 FLOE (Floresta Estadual);

- 13 RDS (Reservas de Desenvolvimento Sustentável);

- 7 FLONA (Floresta Nacional);

- 2 PAF (Projeto de Assentamento Florestal);

- 12 RESEX (Reserva Extrativista);

- 19 PDS (Projeto de Desenvolvimento Sustentável);

- 2 PIC (Projeto Integrado de Colonização);

- 1 PCA (Projeto Casulo de Assentamento);

- 1 PAM (Projeto de Assentamento Municipal);

- 48 PAE (Projeto de Assentamento Agroextrativista Federal);

- 35 PA (Projeto de Assentamento Federal).

O P. A. Tarumã Mirim foi criado pela resolução $n^{\circ} 184 / 92$ de 20 de agosto de 1992, a noroeste da cidade de Manaus, na região compreendida entre as rias fluviais ${ }^{5}$ Tarumã Açu e Tarumã Mirim (mapa 3).

\footnotetext{
${ }^{4}$ O Sistema de Informações de Projetos de Reforma Agrária (SIPRA) destina-se ao tratamento, sistematização e recuperação de dados sobre os Projetos de Reforma Agrária (desde a criação até a sua emancipação), bem como, dos beneficiários (da fase de cadastro, seleção, desenvolvimento sócio-econômico à titulação), propiciando desta forma o conhecimento da realidade nas áreas dos assentamentos. Atualmente o SIPRA tem informações de aspecto econômico-sociais, com registro dos programas ali desenvolvidos, e ainda, o cadastro atualizado de todos os assentados. (INCRA, $2009, s / p)$.

5 Para Guerra (2008, p.544) ria é um tipo de costa de submersão. Todavia, a característica mais importante é a de apresentar rios com a foz totalmente afogada, em virtude de transgressões marinhas.
} 
Mapa 3 - Delimitação do Projeto de Assentamento Tarumã Mirim, Manaus-AM.

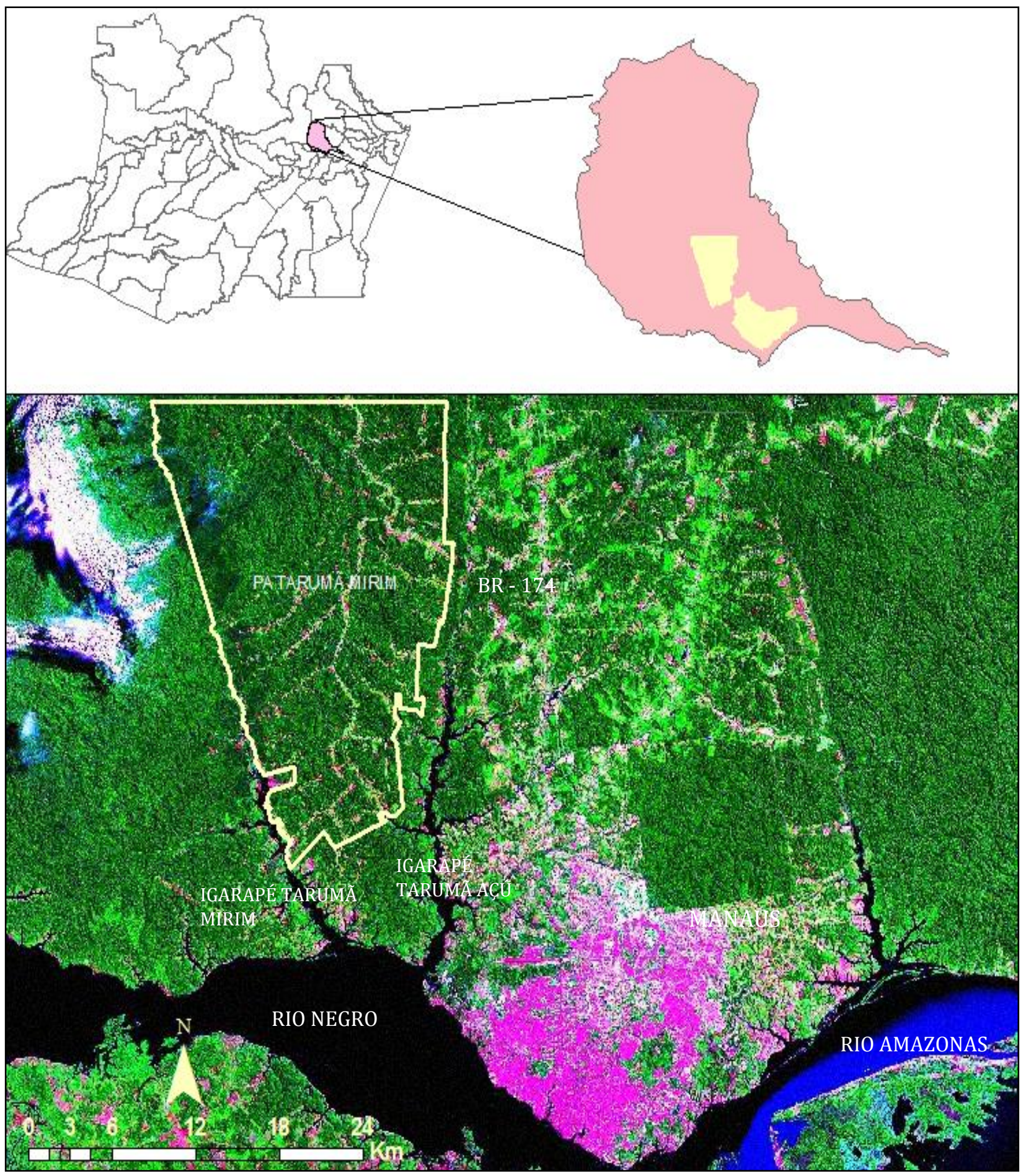

Fonte: CPRM (2011). 
Apresenta uma área de 42.910,7601 ha e na categoria de Projeto de Assentamento Federal é o quarto maior do Amazonas em capacidade, isto quer dizer que pode assentar 1.079 famílias, atualmente (ver quadro 1), apesar de ter sido projetado para assentar 1.042 famílias, conforme consta no diagnóstico sócio econômico ambiental (1999) realizado pelo INCRA.

Quadro 1 - Projetos de Assentamento no Amazonas.

\begin{tabular}{|l|l|l|l|l|}
\hline & Projeto & Município & Capacidade & Beneficiário \\
\hline 1 & PA Rio Juma & Apuí & 7.500 & 5.979 \\
\hline 2 & PAE Bela Vista II & Manaquiri & 3.000 & 2.899 \\
\hline 3 & PA Vila Amazônia & Parintins & 2.478 & 1.767 \\
\hline 4 & PAE Cabaliana I & Caapiranga & 2.000 & 1.907 \\
\hline 5 & PAE Cabaliana II & Manacapuru & 2.000 & 1.975 \\
\hline 6 & PAE Terruã & Pauini & 2.000 & 88 \\
\hline 7 & PAE Purus & Beruri & 1.800 & 1.708 \\
\hline 8 & PA Acari & Novo Aripuanã & 1.773 & 798 \\
\hline 9 & RDS Mamirauá & Maraã & 1.500 & 939 \\
\hline 10 & RESEX Médio Purus & Tapauá & 1.400 & 1.314 \\
\hline 11 & RDS Piagaçu Purus & Anori & 1.200 & 948 \\
\hline 12 & PAE Piranha & Manacapuru & 1.200 & 1.156 \\
\hline 13 & PAE Antimary & Boca do Acre & 1.118 & 384 \\
\hline 14 & PA Tarumã Mirim & Manaus & 1.079 & 1.042 \\
\hline
\end{tabular}

Fonte: INCRA/SIPRA (2011). Org. Souza, 2012.

A alteração na capacidade de assentamento de famílias deve-se ao fracionamento das parcelas para atender às necessidades da família. Para exemplificar, o lote 263 encontra-se dividido em 263, 263-A, 263-B, 263-C, 263-D. Enquanto a família do lote 263-B foi transferida para o lote 731. Na comunidade Pau Rosa há doze lotes nesta situação.

As dificuldades atingiam, em igual proporção, posseiros e assentados. Os projetos destinados ao desenvolvimento socioeconômico dos assentados não foram implementados de forma satisfatória, agravando os problemas. De acordo com depoimentos foram criados dois planos pilotos. Por plano piloto, entendem-se os projetos criados para o cultivo de determinada cultura, visando o fornecimento de 
mudas e apoio técnico para os assentados. É o projeto agrícola que caracteriza um PA.

O primeiro plano piloto foi o "projeto dendê". O segundo foi o plano coco, financiado pela AFEAM (Agência de Fomento do Estado do Amazonas) e o terceiro é o das hortaliças e plantas medicinais.

Esses plano piloto a gente ouviu falá mas foi uma coisa assim, meio bagunçado. A gente via a sede das associação cheia de muda do dendê e quando a gente ia lá pra pegá pra prantá os pessoar da sociação num dava pra ninguém, o INCRA falava que era pro assentamento sê cunhecido como o assentamento do dendê. Mais o que conteceu foi que morreu tudo as muda e num distribuiro nada. (Sr. J. C. B.)

Em vários depoimentos percebemos um descompasso na execução das políticas e a falta de diálogo com os camponeses. O plano de desenvolvimento do assentamento foi determinado pelo Estado por meio de secretarias de produção priorizando a rentabilidade. No entanto, não foi oferecida, a contento, a infraestrutura necessária para o desenvolvimento das atividades nos lotes.

$\mathrm{O}$ argumento de redirecionar os agricultores sem infraestrutura instalados na periferia de Manaus e assim diminuir as ocupações de terras na cidade e abastecimento do mercado consumidor manauara serviu de base para a criação de projetos de assentamento próximos à cidade, conforme disposto no diagnóstico sócio econômico do PA Tarumã Mirim,

Quando criado, o PA tinha como objetivo "promover a adequada ocupação da área, através da absorção de agricultores sem terra que vivem marginalizados em Manaus, evitando invasões ou especulações imobiliárias e possibilitar as condições para sua integração ao processo produtivo regional". (INCRA, 1999, p.3).

O PA Tarumã está dividido em 16 associações comunitárias. Tal divisão foi feita pelo INCRA como uma forma de exercer uma centralidade de influências sociais, considerando a extensão do assentamento. Estas associações fazem parte de uma associação superior, conhecida como Conselhão. "O Conselho de Desenvolvimento das Associações Comunitárias Rurais, composto por representantes das associações, tem o papel de articulá-las internamente, assim como representá-las junto à sociedade em geral". (INCRA, 1999). 
As parcelas têm um tamanho padrão de 25 ha, considerando o módulo rural da região. De acordo com o INCRA, o tamanho das parcelas nos projetos de assentamento diminui de acordo com a proximidade dos grandes centros urbanos. Isto quer dizer que em assentamentos mais distantes da capital os lotes são maiores, exemplo disso é o PA Rio Juma no município de Apuí, Sul do Amazonas, no qual os lotes variam de 60 a 100 ha. Para a construção das benfeitorias podem ser desmatados 4 ha. Os demais 21 ha, são a reserva legal e devem ser preservados.

Essa determinação vai de encontro com os saberes tradicionais. As derrubadas da mata são necessárias para a formação de roças, para em seguida, ocorrer uma nova derrubada e assim a área de roça anterior poder "descansar", é o chamado sistema de pousio ou rotação de culturas. Esta prática permite a regeneração do solo para futuras roças, diminuindo o custo dos camponeses com insumos químicos.

Mas, a política ambiental impede o desmatamento de áreas de floresta primária e em avançado estado de regeneração. As restrições de uso da terra fazem com que os camponeses se sintam deslocados e frustrados com a situação de se ter um sítio e não poder trabalhar da forma desejada. Por isso as expressões agora e antigamente fazem parte do ideário comparativo do que foi e não virá a ser,

Antigamente, no tempo dos meus avós, num tinha assim sabe, o IBAMA em cima de nóis. Agora, parece até que nóis é ladrão, pra gente podê derribá é um sacrifício e é tanto órgão do gunverno que me aparece, na hora que a gente precisa num vem ninguém pra dá uma lata de feijão pra gente prantá, mais vai derribá procê vê. É só cobrança, que se a gente num disinvolvê o lote eles manda tirá nóis, Antigamente a gente prantava o que queria num tinha ninguém que mandava ni nóis. Cumé que nóis pranta agora? Ocê me diz, se num derribá num tem roça, se num tem roça num tem comida, sem comida o home num veve, esse povo veve de quê? De vento? (Sr. J. M. L.)

Esta fala retrata um Estado ausente no momento de oferecer incentivos à agricultura para que os assentados possam vir a se estabilizar "na hora que a gente precisa num vem ninguém pra dá uma lata de feijão pra gente prantá”, no entanto, o mesmo Estado até então ausente, torna-se presente quando se faz uma derrubada, "vai derribá procê vê". 
As exigências quanto à produtividade são descabidas em relação à própria legislação de preservação da reserva legal do lote. Formação de roças indica o desenvolvimento dos lotes, mas é contraditório formar roças onde não se pode desmatar e descumprir a função social determina a devolução de lote para o INCRA "É só cobrança, que se a gente num desinvolvê o lote eles manda tirá nóis".

O fato de o Estado controlar o que deve ser plantado, a partir de planejamentos feitos pelos técnicos agrícolas, denominados de planos pilotos, retira dos camponeses a sua autonomia de decisão das atividades a serem desenvolvidas, esta atribuição que era exclusiva do pai passa a ser do Estado.

Quando há a determinação de proibição da limpeza da área para os cultivares, coloca-se em risco tanto o sustento da família quanto dos consumidores que dependem da produção camponesa, inclusive dos trabalhadores a serviço do Estado, "antigamente a gente prantava o que queria num tinha ninguém que mandava ni nóis. Cumé que nóis pranta agora? Ocê me diz, se num derribá num tem roça, se num tem roça num tem comida, sem comida o home num veve, esse povo veve de quê? De vento?".

As políticas ambientais e agrícolas são vistas como contraditórias pelos camponeses. Ao mesmo tempo em que se apregoa a preservação incondicional se cobra produtividade. Outra contradição observada pelos camponeses se trata das multas e sansões aplicados a eles em casos de descumprimentos de leis ambientais.

Sabe, isso é coisa que a gente num intende né? Só o pobre que leva murta e fica com o nome sujo, aí fica travado, num pode fazê nada, nem mexê com o banco. Se desmata dois arqueire é esse furdunço todo, e os rico que desmata mais de 200 arquere, quê que acontece com eles? Nada! cê já ouviu falá de argum fazêndero ficá prejudicado por causa de murta de IBAMA? Eu nunca vi. (Sra. R. M. T.)

Os camponeses se sentem oprimidos e sem ter a quem recorrer, pois quando um camponês recebe uma multa por crime ambiental há o estigma de "criminoso", sendo então motivo de desonra, há então duas questões postas, se desmata e faz roça é um "destruidor da natureza" se não desmata e mantêm a vegetação é "preguiçoso" e não cumpre a função social da terra, de produção alimentar. 
A proposta de criação do assentamento é datada de 1986 e as atividades dos posseiros foram descritas da seguinte forma, (INCRA, 1986 apud SOARES, 2002, p.26),

\begin{abstract}
As atividades agrícolas desenvolvidas na área dependem de métodos rudimentares, que refletem o empirismo, fruto do baixo nível de conhecimento técnico, resultando numa baixa rentabilidade, tendo como finalidade precípua, apenas manter o homem. [...] A pecuária mostra-se insignificante, representada apenas pelo criatório de um número reduzido de animais de espécies variadas. [grifos meus]
\end{abstract}

O Estado através de suas políticas busca fazer do camponês o agricultor familiar, nesta perspectiva, manter o homem, quer dizer, manter a família não é suficiente, este tem de atender aos padrões capitalistas da rentabilidade. Há em jogo duas visões conflitantes. A do Estado, na tentativa de transformar os camponeses em capitalistas ou mesmo privilegiar a ocupação das terras para os capitalistas e a do campesinato na qual a acumulação/reprodução de capital não faz parte de seu modo de vida.

Nestes casos, os projetos econômicos estão fadados ao fracasso, pois é negligenciada a questão cultural da lógica camponesa de reprodução da família. Dependendo da situação econômica, os camponeses inscritos nos projetos para reforma agrária, foram direcionados para projetos de assentamento próximos à cidade. Existindo os que foram selecionados para assentamentos distantes, e recusando-se a ir, preferiram se tornarem posseiros no PA Tarumã Mirim.

Eu cheguei aqui, eu tô irregular, sabe. Eles (INCRA) queria me colocá lá pros canfudó, lá pro (assentamento) Água Branca, porque disseram que porque eu tinha um carro velho, aí eu podia colocá minha família em qualquer buraco. Esse povo parece que num pensa, tanta gente que eu já tirei daqui mordido de cobra, quase morrendo. Eles qué colocar só gente miserável, e não dão estrutura. A gente pra eles é como se num existisse. (Sr. V.G.S).

A noção de distância precisa ser relativizada. A proximidade com a cidade, não pressupõe maiores facilidades. A maior parte dos trajetos se fazia a pé. $E$ de acordo com os camponeses, assim que demarcaram suas posses, dificilmente se ia a Manaus porque se demorava três dias percorrendo os caminhos abertos na mata, conforme o depoimento da Sra. M. E. C. 
Aqui nós temos esse terreno desde 92, quando a gente pegou esse terreno ele (marido) vinha no pique lá do Novo Israel (bairro na zona norte da cidade), dava uns três dia. Na época tinha estrada até uma certa parte, às vezes ele pegava carona. Meu sogro mora bem ali o seu S., aí veio eles os meu cunhado. Foi através desse pessoal que o INCRA fez o assentamento. Só tinha umas duas pessoa aqui no Pau Rosa, aí se juntaram e abriram a estrada no muque.

Quem chegou primeiro ao lugar em que hoje está a comunidade Pau Rosa, de acordo com depoimentos, foi um funcionário aposentado da Petrobrás e um senhor conhecido como Chico das Canoas. Este último marcou vários lotes para os filhos e "vendeu" um lote com as benfeitorias, que atualmente está irregular.

Outros souberam do assentamento por conhecidos que se preparavam para abrir posse. Há também os que ouviram em rádio e por chamadas na televisão. Quem se inscreveu no INCRA, após os anúncios e não foi selecionado decidiu se instalar como posseiro e após a delimitação do assentamento tornou-se assentado, esta opção não foi seguida por todos os que se encontravam nestas condições, como se verifica no seguinte depoimento.

Eu entrei aqui, mas só queria um pedaço pra trabaiá com os meus fio. Um dia chegaram uns pessoal do INCRA e perguntaram se eu queria fazê parte do assentamento que eles ia fazê. Eu combinei com a muié de não querê. É que se a gente fosse assentado como eles queria que nóis fosse, a gente ia virá era empregado do INCRA, devia satisfação pro INCRA o resto da vida. A gente passa a vida intera querendo deixá de sê empregado pros outro pra virá empregado do governo? O meu sítio aqui tem dez arqueire ${ }^{6}$ e tenho dois fio hôme, se eu morrê cinco arqueire pra cada um tá bom demais. Aí tem que trabalhá, pra não sê humilhado pro ninguém, que trabalhá de empregado pros outro tem que guentá humilhação o tempo todo. (Sr. A. L. C.)

Conforme já assinalado, a área em que atualmente está o assentamento e seu entorno passaram a ser ocupadas desde a década de 1970. Quando o INCRA implementou o assentamento, as famílias que já residiam no lugar foram consultadas para que os seus sítios fossem transformados em lotes para a reforma agrária com metas a serem cumpridas. "Um dia chegaram uns pessoal do INCRA e perguntaram se eu queria fazê parte do assentamento que eles ia fazê. Eu combinei com a muié de não querê".

\footnotetext{
${ }^{6}$ Nos depoimentos o alqueire é considerado como a medida de dois hectares e meio não sendo encontradas outras variações.
} 
Ser assentado e dever satisfação ao governo seriam o equivalente a ter um patrão, sair de uma situação de exploração e assegurar que seus filhos não sejam submetidos a situações humilhantes são as metas dos camponeses. Bombardi (2004, p.134) explica situação semelhante,

\begin{abstract}
A autonomia aparece como a possibilidade de poder ter um "pedaço de terra" próprio, não no sentido de ter uma propriedade em si (propriedade privada capitalista), tanto que se fala em ter "um pedaço", mas pela liberdade que ter a terra própria pode significar, ou seja, em contraposição a ter que "trabalhar pros outros", nas terras de outrem, ter a própria terra significa ter o controle do processo de trabalho e, portanto, do espaço e do tempo.
\end{abstract}

No depoimento é enfatizado o objetivo principal da abertura da posse, o sustento da família, e deixar o suporte necessário para que os filhos também possam sustentar suas respectivas famílias após a morte dos pais e formar seus próprios sítios. "A gente passa a vida intera querendo deixá de sê empregado pros outro pra virá empregado do governo? O meu sítio aqui tem dez arqueire e tenho dois fio hôme, se eu morrê cinco arqueire pra cada um tá bom demais".

A autonomia dos filhos depende do trabalho para que futuramente não precisem se submeter a uma relação de humilhação e dependência, "aí tem que trabalhá, pra não sê humilhado pro ninguém, que trabalhá de empregado pros outro tem que guentá humilhação o tempo todo".

Apesar de um projeto de assentamento requerer normas e metas, sendo comparado inclusive a um novo patrão, contraditoriamente possibilita a distribuição de terra a camponeses. Permanecer posseiro implica uma instabilidade, seja na permanência na terra ou na destinação de infraestrutura básica, que mesmo precária e morosa chega ao assentamento, não é caso das posses. 
2.2Sobreposições de territorialidades: Unidade de conservação versus projeto de assentamento.

O assentamento dos cadastrados/beneficiários do INCRA e que ainda moravam na periferia de Manaus foi feito somente em 1997, no período de transição de governo municipal do atual senador Eduardo Braga (Partido do Movimento Democrático Brasileiro - PMDB) para o ex-ministro dos transportes Alfredo Nascimento (Partido da República - PR).

O retardo da entrega dos lotes para beneficiários é vinculado à criação da Área de Proteção Ambiental - APA Margem Esquerda do Rio Negro - Setor Tarumã Açu Tarumã Mirim sobrepondo-se ao assentamento (SOARES, 2002). Tornava-se uma questão difícil de equacionar. Um projeto de assentamento agrícola determina a supressão da floresta para a implantação das roças enquanto uma unidade de conservação pressupõe a proteção da natureza.

A Área de Proteção Ambiental (APA) foi criada pelo decreto estadual n¹6.498 de 02 de abril de 1995 e "redelimitada pela Lei n²646 de 22 de maio de 2001" (AMAZONAS, 2007, p.66). O perímetro da unidade de conservação (UC) abrange os municípios Manaus, Novo Airão, Manacapuru, Presidente Figueiredo e Rio Preto da Eva e conta com uma área de 56.793ha (ver Anexo D).

Considerando essa dupla característica da área, sendo ao mesmo tempo um PA e uma APA, torna-se relevante assinalar a contradição existente entre os objetivos de uma unidade de conservação de "uso sustentável" e um projeto de assentamento. Isto se evidencia com $\mathrm{o}$ artigo $5^{\circ}$ do decreto $\mathrm{n}^{\circ} 16.498$,

Art. 5. - - Para as atividades agrícolas ou pecuárias que existam ou venham a existir nas APA's, haverá Zonas de Uso Agropecuário, nas quais serão proibidos ou regulados os usos ou práticas capazes de causar sensível degradação do meio ambiente.

1.․ - Não é admitida nessas Zonas a utilização de agrotóxicos e outros biocidas que ofereçam riscos sérios na sua utilização, inclusive no que se refere ao seu poder residual. O Instituto de Desenvolvimento dos Recursos Naturais e Proteção Ambiental do Estado do Amazonas - IMA/AM relacionará as classes de agrotóxicos de uso permitido nas APA's.

2. - - O cultivo da terra será feito de acordo com as práticas de conservação do solo recomendadas pelos órgãos oficiais de extensão agrícola.

$3^{\circ}$ - Não será admitido o pastoreio excessivo, considerando-se como tal aquele que acelerar sensivelmente os processos de erosão. (Decreto $n^{\circ}$ $16.498 / 95$, p.5,6) 
Mapa 4 - APA Margem Esquerda do Rio Negro Setor Tarumã Açu, Tarumã Mirim.

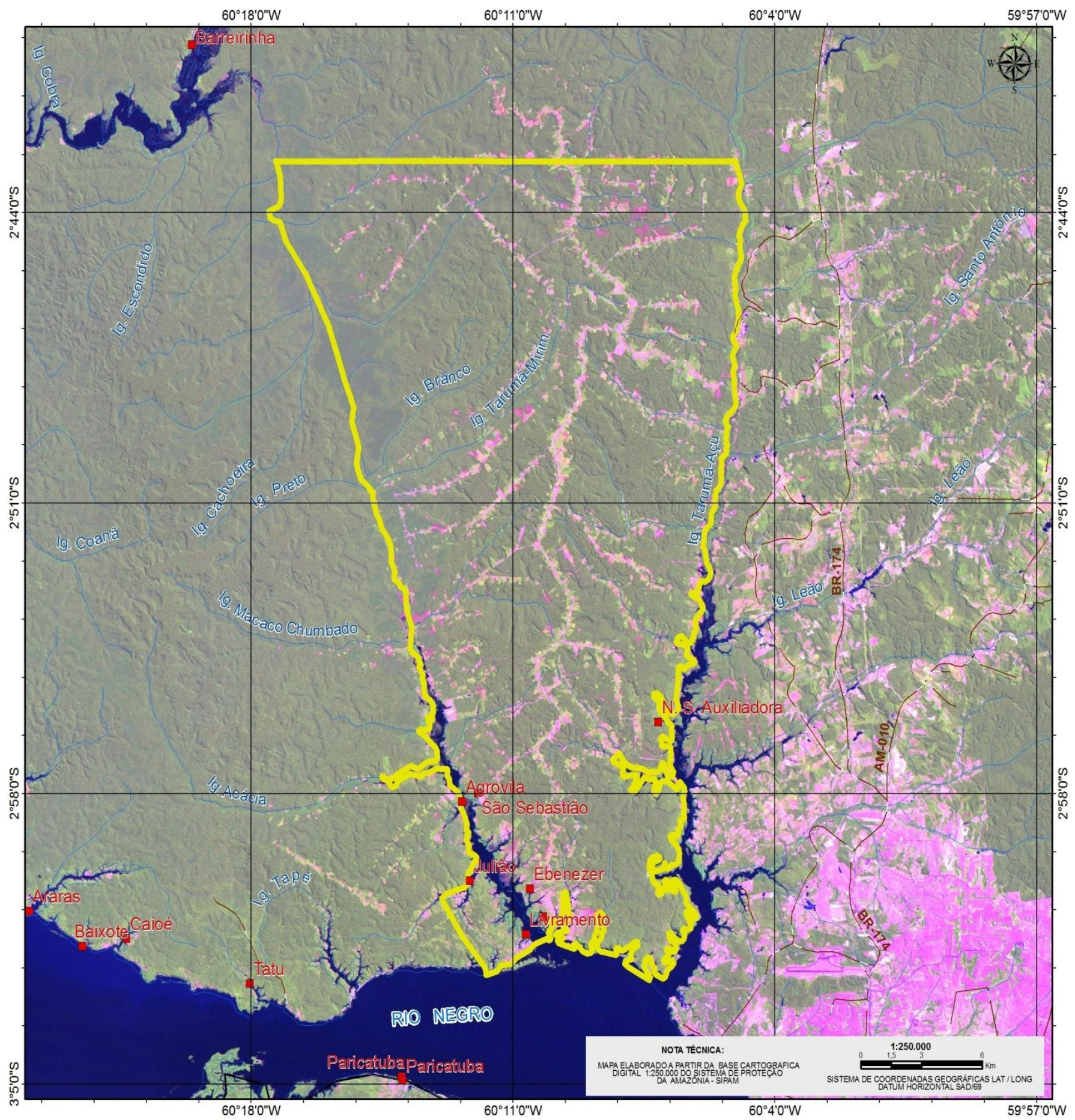

Fonte: IPAAM, 2012. 
Os impasses gerados pelo uso da terra de um assentamento que de repente se torna também uma unidade de conservação, têm em sua raiz a perspectiva de preservação da natureza desprovida de grupos sociais,

\begin{abstract}
A ideia que fundamenta este modelo é a de que a alteração e domesticação de toda a biosfera pelo ser humano é inevitável, sendo necessário e possível conservar pedaços do mundo natural em seu estado originário, antes da intervenção humana. Lugares onde o ser humano possa reverenciar a natureza intocada, refazer suas energias materiais $e$ espirituais e, pesquisar a própria natureza. (ARRUDA, 2000, p.279).
\end{abstract}

A essa característica de dissociar natureza e os povos "tradicionais" é uma forma de centralizar decisões e impedir que os atores envolvidos tenham condições de influenciar nas políticas às quais serão os maiores afetados. No entanto, este modelo de preservação se mostra incompatível com as realidades locais,

\begin{abstract}
Os conservacionistas têm começado a perceber que o plano de proteção de espécies e habitats, mais frequentemente, não dá certo se as dimensões sociais são ignoradas ou se as comunidades são marginalizadas. Já a maioria das políticas de conservação tende a militar contra um envolvimento adequado das populações locais. Dado que a conservação clássica é uma política introduzida, seja por pessoas de fora da região, seja por estrangeiros do país, busca legitimidade e autoridade fazendo alianças com o governo. Por razões óbvias, quando faltam constituições locais ou poder de grupo-alvo (Reid \& Miller, 1989:VI) e esperam que, convencendo-os de seu ponto de vista, podem assegurar mudanças reais alterando o status legal da terra e obrigando os habitantes locais a mudar suas atividades. $O$ resultado é que a abordagem conservanista clássica tende a reforçar as divisões existentes entre populações locais e o governo, aumentando assim a alienação e o conflito em vez de resolvê-los. (COLCHESTER, 2000, p.237)
\end{abstract}

Da forma como se estabelece as normas em relação ao uso da terra é notório o caráter centralizador e burocrático às quais os camponeses estão sujeitos, visto a necessidade de cumprimento das leis ambientais acentuadas pelo criação da APA. Isso faz com que desistam de iniciar um plano de manejo porque as próprias instituições não possuem profissionais que saibam lidar com a forma que os camponeses expõem suas reinvidicações, isto quer dizer, a partir da oralidade.

Enquanto os projetos de assentamento são criados com a finalidade de aumentar a produção agrícola, as unidades de conservação têm por objetivo a 
gestão do território de acordo com o Estado. Assim se percebe essa dualidade na visão dos camponeses.

botaram agente aqui e ponharam o apelido de assentado agricultô, que é aquele que pranta, foi o que disseram pra gente fazê aqui, mais quando chegamo aqui é tanto trem que óia a gente de tudo que é lado, agente é vigiado igual como na fazenda que agente trabaiava, aí todo mundo falava que tinha muita terra aqui (Amazonas). Com a terra nossa memo, agente pode trabaiá como qué, do jeito que os mais véio ensinô, eles num tinha estudo, mais tinha a sabedoria que Deus deu. Ai vem o INCRA que diz que pra gente ficá aqui tem que tê a tar da função social, aí vem IBAMA, SDS e diz que pra gente que num pode fazê derribada, que vai acabá com a natureza, como que a gente vai prantá? Eu vô derribá e prantá, que é pra isso que tamo aqui, se vié IBAMA me multá vô falá pra se entendê com o seu INCRA. Que multa só predijica os pobre que tem o roçado, já os fazendêro nem se incomoda com multa. (Sr. RS)

As incertezas sobre o domínio da área pelo Estado geram esse tipo de empecilho, em que para plantar é necessário cumprir uma série de exigências e nem todos sabem lidar com tal burocracia. Ainda há a situação de quem compra lote para uso de fim de semana e vende os recursos nele existentes como areia, cascalho, seixo, madeira. Os caminhões que levam esses produtos até o seu destino passam pelo ramal Pau Rosa, prejudicando a estrutura da estrada.

Em se tratando de áreas em que tenham recursos como madeira de lei, areia dentre outros, não há uma preocupação com os resultados de tais ações, principalmente com as estradas,

\footnotetext{
Parte da floresta da área foi explorada por madeireiras no início do assentamento, assim que os ramais foram construídos, antes mesmo da chegada das famílias e o corte seletivo ainda é atividade comum nas propriedades. A exploração madeireira é realizada tanto para o consumo interno como para a comercialização com as madeireiras, efetuada, geralmente, sem licenciamento ambiental. $O$ produto da exploração madeireira tem mercado garantido, mas esta atividade além de depauperar os recursos florestais da comunidade, propicia uma baixa rentabilidade e danifica os ramais com o trânsito pesado dos caminhões das madeireiras que compram as toras diretamente nas propriedades. (COSTA et al, 2012, p.18)
}

A recuperação das vias é esporádica e quando as estradas estão em condições melhores vêm os caminhões que carregam materiais pesados na qual um grupo tem acesso aos benefícios em detrimento dos camponeses de todas as comunidades dependentes do ramal. 
Até a chegada a comunidade Pau Rosa, os camponeses apresentaram trajetórias diversificadas. Mas, é notória a presença de migrantes do interior do Amazonas. Quando perguntados sobre os motivos, afirmaram sobre a precariedade dos serviços básicos nas cidades do interior e acompanhamento de parte da família que já havia migrado (NOGUEIRA e MAINBOURG, 2010).

$\mathrm{O}$ deslocamento para Manaus é associado à presença da Zona Franca e às possibilidades de emprego geradas com a presença do pólo industrial. O resultado disso é o crescimento da cidade. Os camponeses se estabeleceram em bairros das periferias de Manaus e são provenientes em sua maioria do Norte e Nordeste do país (gráfico 1).

Gráfico 1 - Estado de origem dos camponeses.

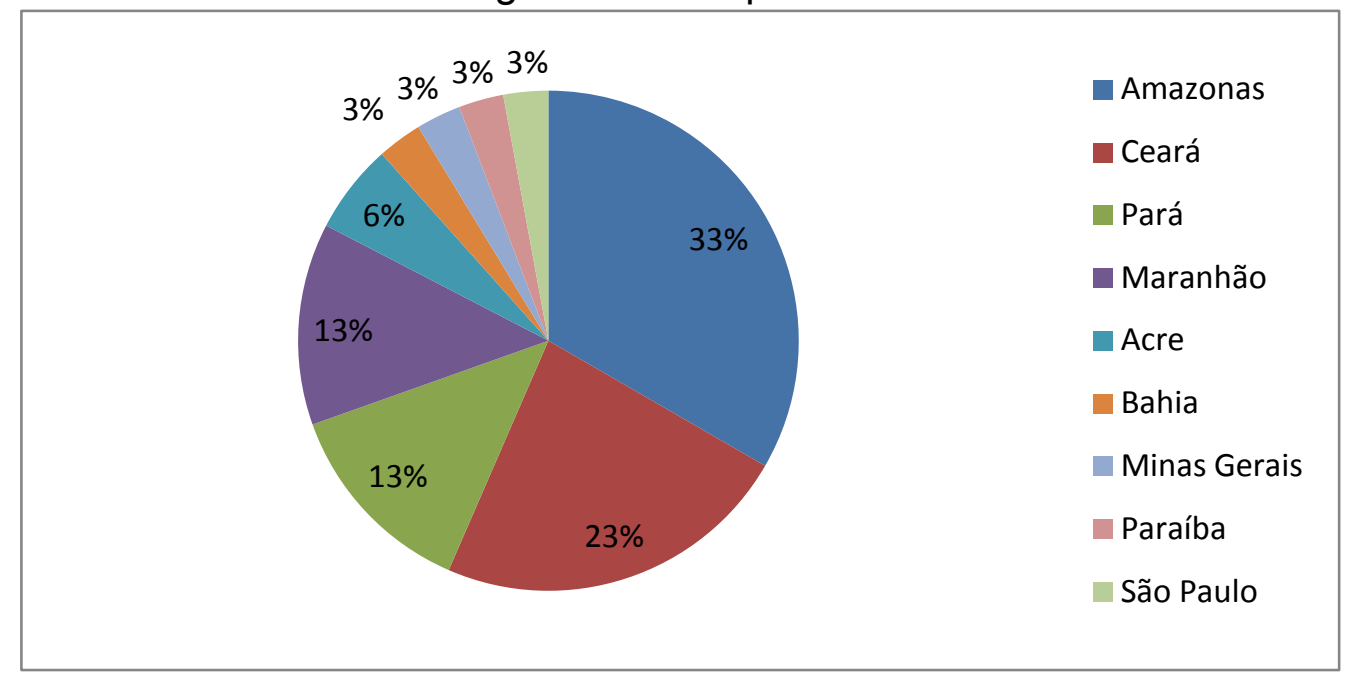

Fonte: Trabalho de campo, 2011-2012.

Foram entrevistadas 60 pessoas; todos chefes de família. Na chegada aos sítios, as mulheres se portavam mais retraídas enquanto os maridos forneciam com maior precisão as informações das perguntas mais diretas como o tamanho do lote $\mathrm{e}$ área roçada. Aos poucos as esposas se sentiam mais familiarizadas com a nossa presença e também começavam a nos mostrar o sítio, a casa, as plantas, os remédios e a forma de preparo.

Do universo de 60 pessoas, 33\% (19 camponeses) é oriundo do interior do estado do Amazonas. Este resultado coincide com o diagnóstico do assentamento (INCRA, 1999) e com o trabalho de Nogueira e Mainbourg (2010). Quanto aos 
motivos da migração, responderam que vieram em busca de melhores escolas para os filhos, trabalho nas indústrias da Zona Franca e pela falta de apoio ao agricultor. Enquanto 23\% (13 pessoas) veio do estado do Ceará. Estes destacaram os comentários sobre a oferta de empregos em Manaus e o fato de já terem algum conhecido ou parente já estabelecido na cidade.

Com $13 \%$ do total estão Pará e Maranhão, (8 entrevistados cada um). São marcantes as histórias destes camponeses. Trabalhando nos garimpos se definiram como "peões do trecho", estavam andando sem rumo, conhecendo os lugares e trabalhando no que aparecesse. Ao constituir a família já se tornava imprescindível ter a terra.

E, com dois entrevistados de cada estado ( $3 \%$ do total) estão Bahia, Minas, Paraíba e São Paulo. Ao chegarem à comunidade, os mineiros e paulistas se viam questionados pelos camponeses que já estavam no assentamento sobre o fato de saírem de dois estados bastante conhecidos e a opção de vir para o Amazonas. A resposta era "não tem terra pra todo mundo".

Os estados citados como de origem dos camponeses apresentam uma geografia agrária de conflito e luta pela terra. O ideal camponês de conquista da autonomia faz com que não cesse a busca de encontrar a terra de trabalho. Como visto, percebe-se um fluxo migratório do Nordeste (Bahia, Ceará, Maranhão, Paraíba) em direção ao Norte (Acre, Amazonas e Pará).

Minas e São Paulo aparecem com pouca expressão, no entanto, é interessante notar no depoimento a visão sobre as terras da Amazônia e a impossibilidade de se conseguir terra nesses estados,

Eu vim pra cá com toda a família, lá em São Paulo nem em sonho eu
podia imaginar em ter uma terra assim, isso aqui é uma riqueza, lá
quem tem uma terra dessa é rico. Lá (São Paulo) só quem tem muito
dinheiro que pode "vivê tranquilo" numa terra. Cresci vendo meu pai
trabalhá pros fazendeiro até que veio uns parente dizendo que aqui é
mais fácil de se conseguir terra, nós vive um sonho, aqui a gente
nunca acordou com jagunço mandando a gente sair, tocando fogo e
ameaçando. (Sra. E.G.S.)

A "riqueza" a qual se refere é a que possibilita a reprodução da família camponesa. Em sua terra de origem o fato do pai trabalhar para um fazendeiro o impedia de cuidar da família. Para Woortmann (1990) a família é o elemento central do discurso camponês juntamente com o trabalho e a terra. Ademais, representam 
uma unidade. Estes componentes são pensados de forma conjunta e isso nos leva a compreender a migração em busca de terra, pois é nela que a família se realiza.

A presença da família estaria marcada pelo trabalho e poucas transformações poderiam indicar desleixo ou incapacidade do pai de família em direcionar corretamente as tarefas. Para tanto, notava-se a moradia precária, o relato da roça que não deu certo, existia as tentativas para saber o que compensava plantar, explanavam-se as metas de construção da casa ou mesmo a mudança do lugar, fazer canteiros $^{7}$ e hortas para as mulheres plantarem as verduras e plantas medicinais.

No início dos trabalhos de campo, os chefes de família se referiam à terra como "lote" por haver pouco trabalho e por ser recebido pelo INCRA neste termo, isto é, não era concebida como uma propriedade camponesa. Esta dimensão é encontrada no trabalho de Bombardi (2004, p.148) ao retratar a oposição entre sítio e lote como a construção do território camponês através do trabalho da família,

\begin{abstract}
Chamo o sítio de unidade territorial, entendendo que, à medida que os camponeses adquirem sua terra e a autonomia sobre ela, passam a forjar uma fração territorial diferente do território capitalista, já que as relações que se dão no interior do sítio não são relações capitalistas, embora estejam inseridas no modo capitalista de produção [...]. O lote, palavra utilizada pelo Estado para definir as pequenas propriedades do Núcleo Agrário Capivari, passou a deixar de ser lote e tornar-se sítio, à medida que as famílias foram chegando, cultivando-o e chamando-o de sítio, numa perspectiva de que esse processo se deu a partir da transformação que nele fizeram através do trabalho da família, ou seja, o trabalho de "formar" um sítio: o trabalho de transformação do território.
\end{abstract}

Ao longo do trabalho, as referências foram mudando. O termo lote vinha sendo gradativamente substituído pelo termo sítio. O lote tem um número e retrata o estado em que foi recebido pelo INCRA, enquanto o sítio tem um nome e denota a transformação exercida pelo trabalho,

O sítio é o lugar do trabalho por excelência. Mas ele é igualmente o
resultado do trabalho, pois é um espaço construído; melhor dizendo, um
conjunto de espaços articulados entre si, que lhe permite organizar-se como
um sistema de insumos e produtos. Esse espaço é o resultado, também, de
um processo histórico secular em que o ambiente foi alterado, com a

\footnotetext{
${ }^{7}$ Os canteiros são estruturas em formato de mesas, circundadas por tábuas que são preenchidas com terra e esterco onde são cultivadas hortaliças e estão suspensas a mais de $1 \mathrm{~m}$ do chão. Quando se pretende proteger das galinhas, mais distante do chão é o canteiro.
} 
gradativa eliminação da cobertura vegetal original e de todo o ecossistema que lhe era associado. (WORTMANN e WORTMANN, 1997, p. 27).

Da forma como se veem, os camponeses se autoidentificam como lavradores e agricultores. Por isso, mostrar o que foi plantado, as hortas, a casa de farinha (foto 1), ou seja, o resultado do trabalho justifica o que são e, portanto, são merecedores de um lote para a reforma agrária.

Foto 1 - Casa de farinha

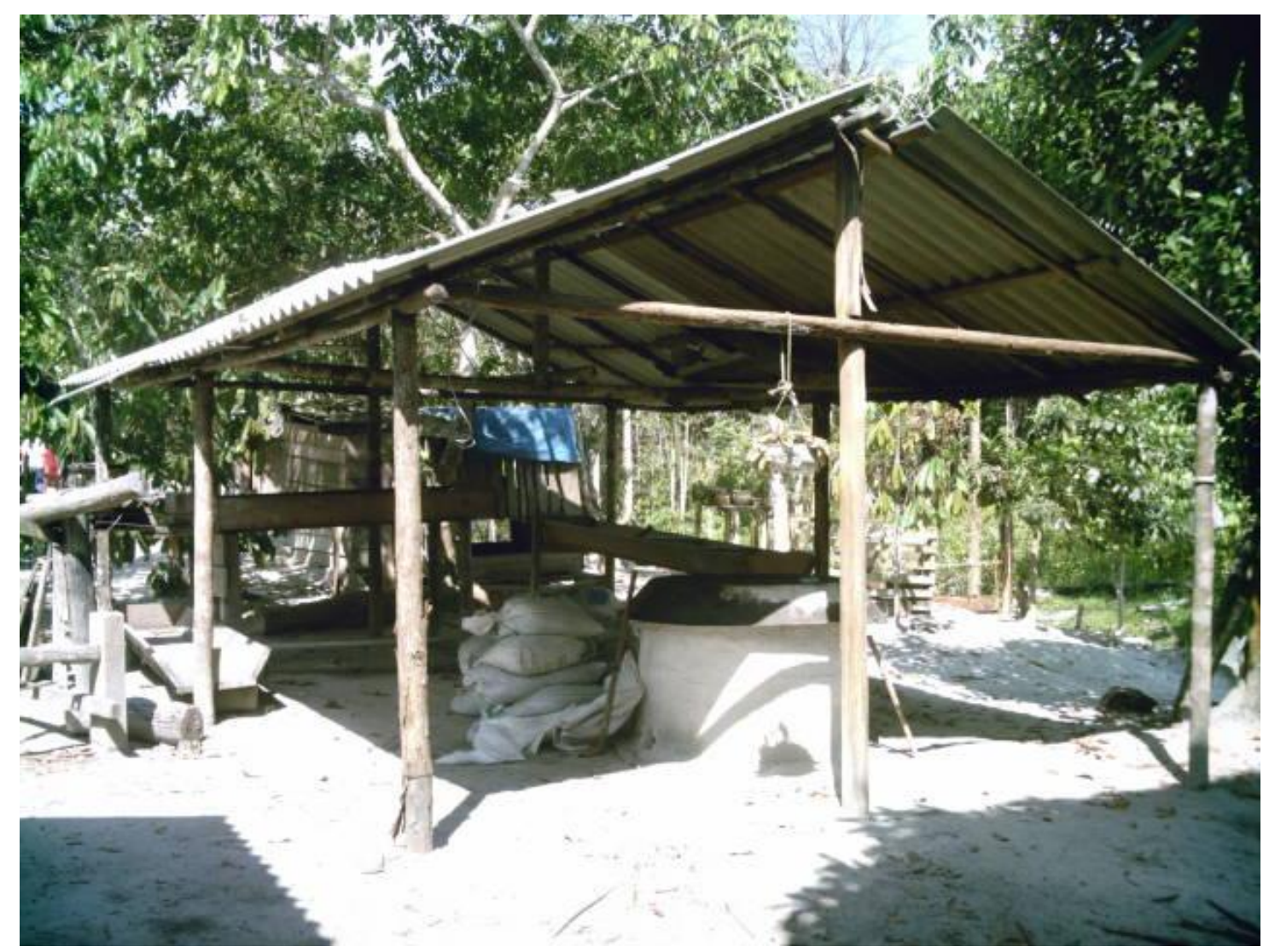

Fonte: Trabalho de campo 2011-2012.

A farinha é um elemento importante nos hábitos alimentares dos camponeses, assim, há a preocupação em ter nos sítios uma roça de mandioca e a casa para o preparo da farinha. Esta estrutura é partilhada, contribuindo para o estreitamento dos laços de solidariedade, contribuindo para boas relações de vizinhança. 


\subsection{Organização social do campesinato.}

Atualmente na comunidade Pau Rosa existe a associação de moradores e duas associações de produtores. A associação de moradores foi criada pelo INCRA e foi presidida por doze anos pelo Sr. Narlon Silva. Após o seu falecimento quem assumiu foi o Sr. Claudionor Costa. A associação comunitária não é bem vista por todos os camponeses. O Sr. R.S. afirma ter buscado ajuda com os documentos de associado após sofrer um avc, mas não obteve retorno.

O Sr. Claudionor alega ser difícil unir os associados porque a proximidade com a cidade faz deles "independentes". Qualquer questão burocrática pode ser resolvida em Manaus e isso propiciaria o individualismo. No entanto, a maior parte das demandas está relacionada com a produção. Neste sentido, as associações de produtores são mais respeitadas em relação à associação de moradores.

Isto ocorre porque a associação de moradores existe para requerer obras e serviços de infraestrutura diretamente com o INCRA. Enquanto as associações de produtores estabelecem parcerias com instituições do poder público municipal, estadual. Quando se consegue algum benefício é considerado como resultado do empenho da associação dos produtores. Mas, se algo não vem através da associação de moradores, esta passa a ser considerada fraca e seu presidente tido como um incapaz.

Após a implantação do assentamento e os sucessivos fracassos dos planos pilotos, o Tarumã Mirim ficou conhecido com o "assentamento do carvão". Os camponeses tiveram acesso à terra, mas não às condições para trabalhar, num primeiro momento produziam o carvão, pois sem estradas e meios de transporte adequados não conseguiam levar sua produção para o mercado. Enquanto, o comprador do carvão buscava a produção diretamente no lote, apesar das péssimas condições das estradas vicinais (MACHADO, SOUZA, COSTA, 2009).

Nestas circunstâncias, a associação de moradores passou a ficar em descrédito por não oferecer resultados práticos para os problemas de infraestrutura e de produção. Os camponeses viviam em condições precárias, produzindo carvão e levando frutas e verduras em pouca quantidade, o que era possível carregar, em ônibus do transporte coletivo e vendendo a pessoas conhecidas em Manaus.

Somente com a organização camponesa, que culminou na criação da ASSAGRI (Associação de Agricultores do Pau Rosa), os camponeses passaram a 
se sustentar com a produção e venda de hortaliças, frutas, plantas medicinais e pequenos animais nas feiras em Manaus.

Outra associação foi criada com a participação de camponeses da comunidade Pau Rosa, a APOAM (Associação de Produtores Orgânicos do Amazonas), mas que atenderá agricultores de municípios vizinhos.

Estas duas associações serão tratadas nos subitens seguintes. 
2.4.1 A ASSAGRI e a feira do Produtor.

Associação de Agricultores do Pau Rosa foi fundada em 2006, com a proposta de organizar os produtores e reivindicar o apoio das instituições para a comercialização da produção em feiras de Manaus. Os camponeses se revezam em duas feiras. A feira municipal da Zona Leste, mais conhecida como feira do produtor do bairro Jorge Teixeira, e a feira da SEPROR, EXPOAGRO (mapa 5).

Mapa 5 - Localização das feiras em relação ao assentamento.

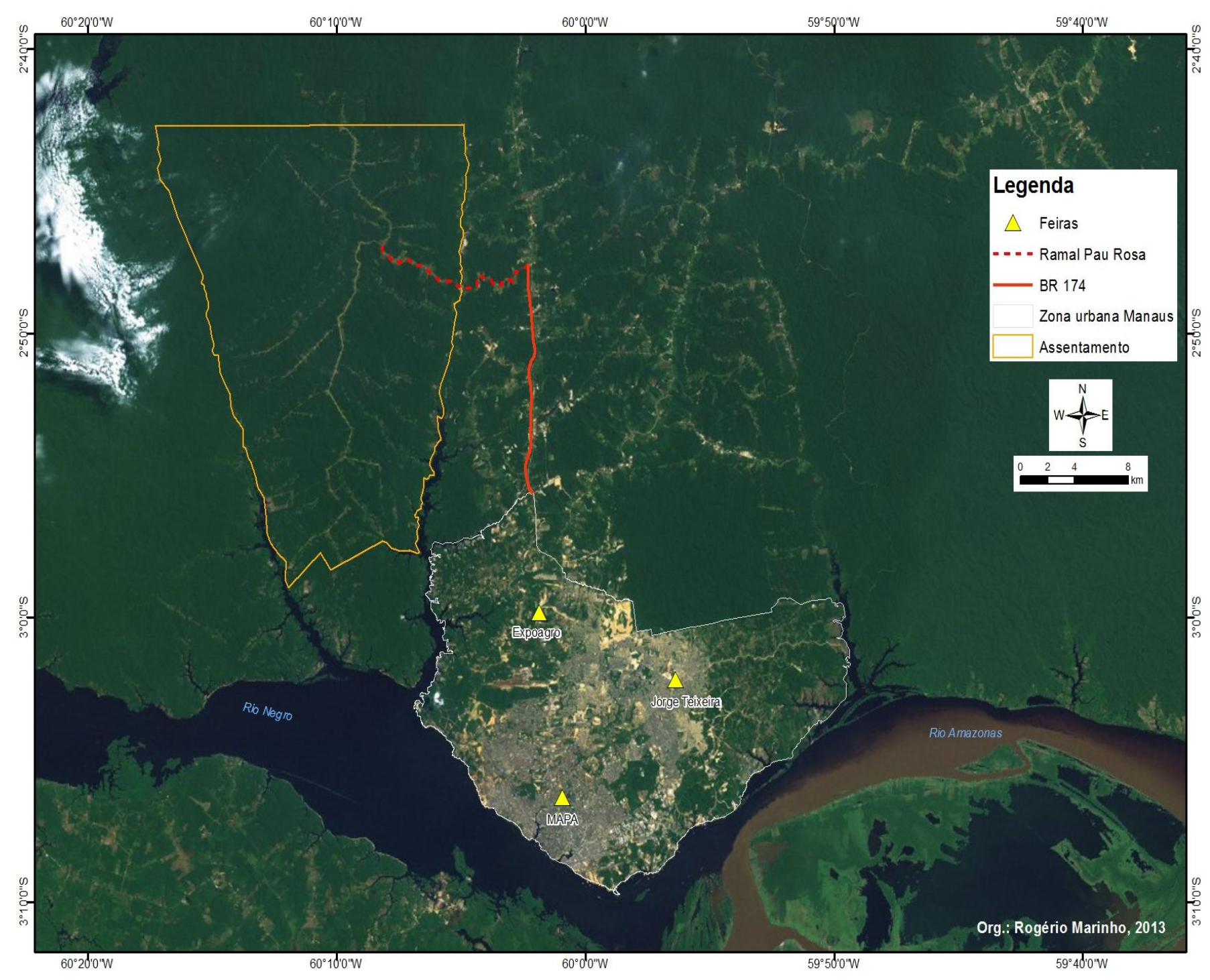

Org.: Marinho, R. R. 2013. 
A produção levada às feiras é principalmente de frutas, legumes, hortaliças e plantas medicinais. No quadro 2 estão expostos os cultivares levados às feiras. No entanto, estes itens não são fixos, dependem do que se está sendo produzido em cada sítio.

Quadro 2 - Cultivares destinados para as feiras

\begin{tabular}{|l|c|l|c|}
\hline \multicolumn{1}{|c|}{ Cultura } & Sistema de plantio & Época que planta & $\begin{array}{c}\text { Período de } \\
\text { Desenvolvimento }\end{array}$ \\
\hline Abacaxi & Cova & Qualquer época & 6 meses \\
\hline Alface & Leira & Todo tempo & 45 dias \\
\hline Banana & Cova & Setembro & 3 meses \\
\hline Batata doce & Cova & Qualquer época & 90 dias \\
\hline Cebola de palha & Leira & Todo tempo & 1 mês \\
\hline Chicória & Leira & Todo tempo & 2 mês \\
\hline Coentro & Leira & Todo tempo & 1 mês \\
\hline Couve & Leira & Qualquer época & Menos de 90 dias \\
\hline Cupuaçu & Cova & Janeiro & 3 anos \\
\hline Feijão & Cova & Setembro & 45 dias \\
\hline Feijão de metro & Leira & Qualquer época & 3 mês \\
\hline Graviola & Cova & Janeiro & 4 anos \\
\hline Ingá & Cova & Janeiro & Mai-Set-Mar \\
\hline Laranja & Cova & Junho & 2,5 anos \\
\hline Macaxeira & Cova & Todo tempo & 6 meses \\
\hline Mandioca & Cova & Todo tempo & 1 ano \\
\hline Manga & Cova & Todo tempo & 3 anos \\
\hline Mari mari & Cova & Todo tempo & 3 anos \\
\hline Quiabo & Leira & Junho & Outubro \\
\hline
\end{tabular}

Fonte: Trabalhos de campo, 2011 - 2013.

É costume levar a produção de quem permanece no sítio, e naquele momento não pode ir à feira, no retorno, entregar o dinheiro integralmente correspondente à venda. $\mathrm{O}$ trabalho de cuidar das hortas e da roça é de responsabilidade da família que fica no sítio.

Tem semana que a gente vai, tem semana que tem muito serviço no sítio. Às veiz a gente num tem o que mandá, aí a gente manda o que tem por um dos cumpadre que vai, ele vende pra gente e depois nóis se acerta. Minha mãe sempre falava que a gente tem que ajudá os outro porque dô de barriga num dá só uma veiz. Hoje nóis precisa dele, amanhã eles que pode precisá de nóis? Num é memo? Já cansei de levá a produção do conhecido, a gente num cobra nada. Aí quando a gente precisa eles leva pra nóis tamém. Aqui todo mundo se ajuda. (Sra. E. M. D) 
As trocas de favores são o "depois nóis se acerta", o cuidado dos cultivares e a venda da produção em Manaus, não implica o pagamento em dinheiro, mas o compromisso em ser solidário quando alguém se encontrar em situação de dificuldade. Não se trata de uma obrigação formal, como a empregada numa relação de assalariamento, mas de uma obrigação moral, na qual a prestação de um favor ajuda a superar a deficiência de mão de obra. Esta dimensão é encontrada na obra de Brandão (1995, p.162),

[...] Uma relação entre pessoas do lugar regida por transações de direito-edever e para a realização de seu motivo, implica um duro trabalho. Quando ela é vivida autonomamente entre sujeito social e culturalmente iguais, ou tornados semelhantes naquela situação e para os seus efeitos, a experiência de um envolvimento próximo à participação obrigatória tornase afetiva e simbolicamente uma partilha de convivência. Por isso, os mutirões e as trocas de dias são ritos do trabalho, enquanto um "dia de labuta" de dois camaradas empregados a um fazendeiro é um trabalho sem o rito.

Ajudar um compadre em momentos difíceis garante a retribuição de um favor, por isso a expressão "dor de barriga num dá só uma veiz", ou seja, as práticas de solidariedade se retroalimentam. As relações de solidariedade camponesa se expressa nesses laços de companheirismo determinando as práticas de ajuda mútua, assim definida por Santos (1978, p.34 e 35).

No bairro São Pedro, a força de trabalho necessária para mover a lavoura é complementada pelos braços dos camponeses vizinhos. As práticas de ajuda mútua aparecem seja sob a forma de mutirão, seja sobre troca de dias. [...] A ajuda mútua aparece aqui como um processo grupal, concorrendo as pessoas espontaneamente para prestar o auxílio necessário.

Localmente o mutirão, caracterizado por Santos (1978) é conhecido por ajuri, como é observado na seguinte entrevista,

Aqui na área do Pau Rosa tem quatro famílias que participam lá da feira (APOAM), mas tem dezessete ou vinte que tão se preparando pra entrar. Tem umas pessoa que nóis tem que se ajuntá pra fazê o ajuri. [o que é ajuri?] Ajuri é se juntá um grupo de produtores, por exemplo, vai fazê compostagem, vai plantá sem queimá, vai plantá numa área que tá desmatada, só areia. Aí a gente tem que fazê alguma coisa pra melhorá aquela área praquele parceiro. Por exemplo, planta ingá. Quê que dá na areia? Batata? Planta batata. Feijão? Planta feijão. Maxixe? O quê que dá pra cultivá na areia, 
pode plantá abacaxi, pode plantá o caju, coisa que dá na areia, hortaliça não dá na areia, só se for barro com areia. (Sra. E. G.).

Esta é uma das formas de ajuda mútua, na qual os camponeses se juntam para fazer o plantio para os parceiros. Não há pagamento de diárias pelo trabalho, mas a obrigação moral de ajudar, por meio de outro ajuri, um parceiro com pouca mão de obra.

A ajuda é um termo frequente nos depoimentos, "a gente se ajuda" implica reciprocidade de ações. Ajuda-se a quem precisa, e este quando não precisar mais, também pode vir a ajudar outros, que em situação de crise necessitam de auxílio.

A Sra. R. S. V. mora com o marido temporariamente no sítio da senhora M. E. P. porque no seu lote não passa estrada e os amigos - para ajudar - permitiram morar e fazer hortas em seu sítio enquanto aguardam a abertura da estrada. Os dois casais moram na mesma casa, mas cada qual possui suas próprias hortas trabalhando juntos.

Compartilhar a moradia, além de uma forma de ajudar "os compadres", é a garantia de companhia. Ter alguém para conversar, tomar um café é importante para o convívio social. Enquanto as duas mulheres vão à feira nos fins de semana vender a produção, os maridos permanecem nos sítios cuidando das hortas, fazendo companhia um ao outro.

A feira do produtor é a preferida pelos camponeses por ser mais movimentada. De acordo com eles, é "mais alegre" e na maior parte das vezes conseguem vender tudo o que trazem. O fato de a feira estar localizada na Zona Leste da cidade contribui para a preferência da feira do produtor do bairro Jorge Teixeira. Pois é onde reencontram os parentes e antigos vizinhos, visto a maior parte dos camponeses já terem sido moradores de bairros localizados nesta zona da cidade.

A feira do produtor funciona todos os dias da semana, no entanto, nem todos os vendedores são os produtores rurais. Os camponeses associados à ASSAGRI participam todos os fins de semana, porque trabalham com produtos perecíveis, assim quem possui horta "produzindo", ou seja, no período de colheita pode participar das feiras. Nesta feira, nem todos os feirantes são produtores. 
trabaio nosso, compra roupa, panela... As coisa que a gente precisa, a senhora sabe que muié gosta de cuidá de casa que tem de tudo, uma TV, rádio, freza (freezer), fogão..., essa é a nossa luta, trabaiá pra tê de tudo em casa, pra vivê bem. Aí a gente trabaia, trabaia, pra vê um camarada ganhá no nosso lombo? Agora, as coisa tão miorando, as feira são boa, a gente já tá mais equilibrado, já dá pra mandá os menino pra cidade, estudá. As veiz, a mulecada tem que vortá pra ajudá, as veiz a gente chama os cumpadre, eles ajuda, ô a gente paga umas diária..., se continuá assim a gente cresce mais.

Por isso ela é conhecida entre os camponeses como "feira do atravessador", conforme exposto em depoimento, "Aí a gente trabaia, trabaia, pra vê um camarada ganhá no nosso lombo?", a organização camponesa em torno da ASSAGRI foi a forma de romper a dependência dos atravessadores,

As organizações políticas surgem como estratégia de defesa dos camponeses à ação dos intermediários que agem na escala de mercado, ou seja, como forma de inibir a ação dos atravessadores que "facilitam" o processo de circulação de mercadorias. (MACHADO e MATOS; 2010, p.2).

Comercializar a própria produção permitiu aos camponeses perceberem o quanto ficava retido com o atravessador o necessário para se viver bem. A melhora na situação econômica consente que os filhos estudem na cidade, e só em momentos de muito trabalho é requerido o seu retorno, mas há outra forma de suprir essa deficiência de mão de obra, é a troca de dias de serviço,

[...] ocorrendo situações em que uma família camponesa tem necessidade de força de trabalho suplementar. [...] Quando não é capaz de dar conta do serviço somente com a sua família, o camponês pede auxílio ao vizinho, havendo expectativa de que retribua com um tempo de trabalho equivalente. Essa retribuição é feita de modo particularizado, diretamente do camponês que recebeu ajuda àquele que a forneceu. (SANTOS, 1978, p.36)

Quando os compadres ajudam é preciso retribuir o tempo de trabalho, pois ao deixar seus sítios o trabalho fica atrasado. Em geral, as trocas de dias ocorrem quando se trata de camponeses recém-chegados à associação ou em caso de doença, estando a família numa situação de fraqueza.

Em se tratando de um camponês com melhor situação econômica há o assalariamento temporário "ô a gente paga umas diária". Isto não quer dizer que haverá a contratação permanente de outro camponês, pelo contrário, "passa a ser 
um assalariado temporário, cuja família não basta para o desempenho das tarefas agrícolas". (SANTOS, 1978, p.37).

Após o dia de trabalho os camponeses vão dormir na casa de parentes ou conhecidos, e retornam às $04 \mathrm{~h}$ do dia seguinte, quem não tem parente dorme na própria feira, em redes atadas por entre as bancas. Cada família possui uma "pedra", se trata do lugar delimitado para a exposição dos produtos, medindo $3 \times 2 \mathrm{~m}$, e pagam $R \$ 5,00$ por semana para o pagamento de vigilância e limpeza.

Os camponeses iniciam as atividades na sexta feira pela manhã, saindo de madrugada do assentamento e retornam no domingo à tarde ou segunda feira de manhã após arrumar os utensílios para o retorno.

O transporte da produção é feito em caminhões baú e por um ônibus adaptado para trazer os agricultores e uma parte da produção, chamado de "formigão", cedidos pela Secretaria de Produção (SEPROR). O combustível é pago pelos associados da ASSAGRI. Na segunda feira de manhã o caminhão baú, cedido pelo Instituto de Desenvolvimento Agropecuário e Florestal Sustentável (IDAM), retorna à comunidade trazendo os utensílios vazios e os insumos comprados na cidade. Os camponeses retornam aos sítios por ônibus de transporte coletivo. 


\subsubsection{A feira da EXPOAGRO}

Uma das políticas da Secretaria de Produção (SEPROR) é a de organizar uma feira exclusivamente para os camponeses produtores das comunidades próximas à Manaus para eliminar o chamado "atravessador". A feira do produtor do Jorge Teixeira está com a capacidade esgotada e por isso fizeram a feira do Parque de Exposições Agropecuárias Eurípedes Ferreira Lins (EXPOAGRO).

A feira da EXPOAGRO conta com uma infraestrutura padronizada, na qual cada camponês possui sua própria banca. No entanto, por estar mais afastada dos bairros mais populosos não atrai tantos consumidores. De acordo com o seguinte depoimento,

Se eu ainda morasse na cidade, eu tamém num vinha aqui (feira da EXPOAGRO), aqui é longe de tudo. Se tivé carro gasta cum gasolina e pra conseguir pegá um ônibus aqui na cidade é difíci, quem é que vem fazê feira pra cá? Só quem é daqui de perto. Boa é a feira do produtor, lá é o tempo todo saindo e entrando gente, aí a gente faz mais amizade. Mas aí a gente tem que vim pra cá prá fazê essa feira crescê. Aqui é tudo limpim, ajeitadim, mais até pra uriná a gente paga. A gente paga $R \$ 0,50$ prá uriná e $R \$ 1,00$ pra tomá banho. (Sra. R. S. V.)

As famílias camponesas se revezam nas feiras do produtor e da EXPOAGRO (foto 2). Quem direciona as famílias para as feiras é o presidente da ASSAGRI. Para o Sr. Antonivaldo, ex-presidente da ASSAGRI, o objetivo principal em participar das feiras é "mostrar serviço", a venda da produção deve refletir o empenho dos agricultores em produzir, mesmo que sem apoio do governo. Esta seria uma forma de cobrança mostrando o seguinte "olha o que nós faz sem apoio, e se a gente tiver vai fazer mais". 
Foto 2 - Chegada dos camponeses à feira da EXPOAGRO

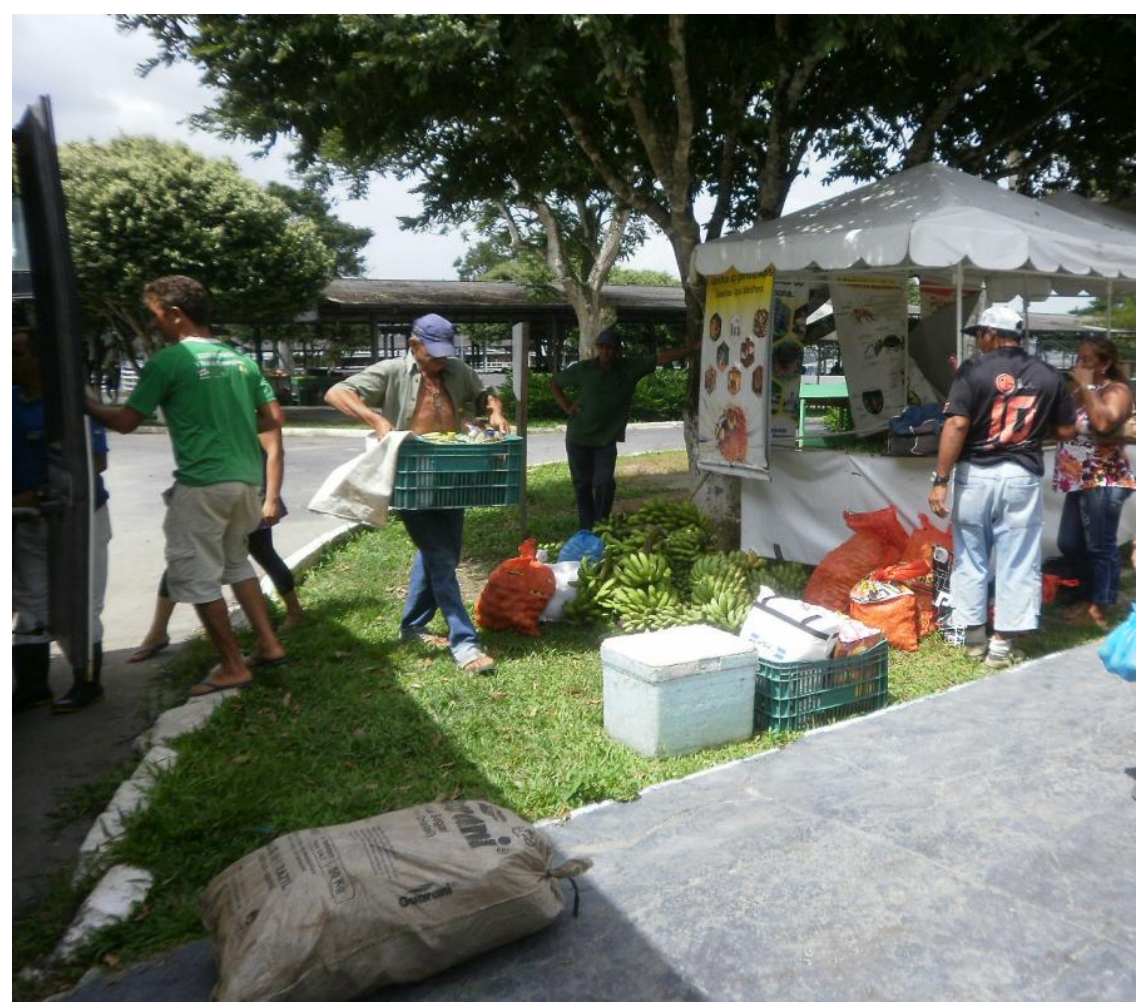

Fonte: Trabalho de campo 2010-2012.

A associação de agricultores do Pau Rosa participa de duas feiras anuais. São as chamadas feiras de participação. A feira do INCRA e a FEPAGRO (Feira de Produtos da Agricultura Familiar) antiga escola agrícola, atual Instituto Federal do Amazonas (IFAM - Campus Leste). É importante a participação nestes eventos para divulgar as ações dos camponeses assentados. 


\subsubsection{A feira do MAPA.}

Esta associação integra camponeses das comunidades rurais dos municípios de Presidente Figueiredo, Iranduba, Manacapuru, Rio Preto da Eva, Manaus inclusive, da comunidade Pau Rosa, vinculada ao projeto tipiti, via INCRA. Assim se verifica no depoimento de uma das integrantes da APOAM,

é assim, é daqui de Manaus, tem do $P$. A. Tarumã Mirim, tem do rio Branquinho, tem do Brasileirinho, tem do Cacau Pirêra, aí se junta lá todos, que ninguém se conhecia né. Agora todo mundo se conhece, vai um na casa do outro, mas em conjunto né, quando tem um trabalho pra fazer vão gente daqui pra lá ou vem eles de lá pra cá ou senão vai lá pro $67(\mathrm{~km})$, já foi feito alguns cursos, alguns mutirões pra aprender a fazer as coisas, orgânico, compostagem. (Sra. E. G.)

Este grupo trabalha exclusivamente com a agricultura orgânica e comercializa a produção na feira que funciona aos sábados na sede do Ministério da Agricultura Pecuária e Abastecimento (MAPA). Trata-se da APOAM (Associação dos Produtores Orgânicos do Amazonas), criada em 2010. Esta associação não é restrita ao assentamento Tarumã Mirim. Dela podem participar os interessados em desenvolver a agricultura orgânica, conforme já explanado. Mas quatro famílias da comunidade Pau Rosa já fazem parte, e mais vinte estão se preparando para entrar.

Parte dessas famílias deixará a ASSAGRI para integrar a APOAM por causa de uma crise gerada pela saída do Sr. Antonivaldo, que vai presidir outra associação de agricultores de Manaus municípios próximos a ela como Rio Preto da Eva, Iranduba e Presidente Figueiredo. Esta nova associação vai administrar a feira da EXPOAGRO.

As famílias que pretendem fazer parte da APOAM precisam fazer cursos sobre adubo orgânico, como preparar a terra sem queimar, podar. Estes cursos são oferecidos pelo INPA, EMBRAPA, SEMPAB, e por técnicos levados pelo presidente da APOAM, o Sr. Moura, conforme depoimento,

A EMBRAPA também nos ajuda, a fazer oficina, é, o pessoal da SEMPAB também, vêm o seu Moura, o presidente da associação dos produtores orgânicos do Amazonas, ele vem com os técnicos da SEMPAB, fazer biofertilizante, fazer a cauda bordaleza, fazer o chorume, aí tudo a gente faz. O INPA também ajudou.(Sra. E. G.) 
Para transportar a produção até Manaus, os camponeses da comunidade Pau Rosa que fazem parte da APOAM utilizam uma Kombi fretada e o custo é dividido entre os associados. Por enquanto, não contam com apoio da secretaria estadual de produção (SEPROR/IDAM), dessa forma todos os custos são dos associados.

A feira funciona de forma improvisada no estacionamento do MAPA. Estabelecidas as parcerias, é possível dispor de bancas permanentes no Parque de Exposições Agropecuárias.

O fato dos camponeses comercializarem sua produção diretamente nas feiras remete a forma de conseguir realizar sua autonomia. Esta perspectiva se encontra no trabalho de Woortmann (1990, p.37) "[...] Vender a própria produção e realizar o valor monetário do trabalho é expressão da autonomia camponesa".

Antes do melhoramento das estradas, a produção chegava aos mercados e feiras de Manaus por meio de atravessadores. Estes são pessoas que possuem um veículo, em geral um caminhão, e compram a produção camponesa diretamente nos sítios buscando diminuir ao mínimo o valor dos produtos.

Os camponeses ao comercializarem diretamente a produção nas feiras, evitam a subordinação de sua renda ao capital (BOMBARDI, 2004). Necessitando criar mecanismos para tanto. Dentre os quais surge a cooperativa. 


\subsection{Especulação imobiliária.}

A localização do assentamento a $21 \mathrm{~km}$ da cidade de Manaus incide sobre a especulação das parcelas para a transformação em sítios de fim de semana (SOUZA, 2008). Nestes "sítios", as casas são semelhantes às da cidade, com piscina e churrasqueira, ou seja, é uma unidade direcionada para o lazer, uma segunda moradia ficando aos cuidados de um caseiro. Florentino citado por Silva (2012, p. 5) explica esse contexto,

[...] os assentados que vivem na cidade "cuja atividade principal não é a agricultura, mas que possuem um lote agrícola, pode indicar a existência de "dupla atividade", ou seja, além da sua atividade na cidade, o urbano pode investir em tempo, trabalho e capital na sua propriedade rural".

Sobre a comunidade Pau Rosa a especulação é maior do que nas outras comunidades por ela ser a única com acesso pela rodovia BR 174 (Manaus - Boa Vista) e o ramal é o único asfaltado. Nas demais estradas e vicinais, há a manutenção esporádica com a piçarra ${ }^{8}$.

A venda das parcelas é vista pelos camponeses como um sinal de fraqueza, haja vista a dificuldade de se conseguir terra. Em trabalho de campo realizado em março de 2012 a associação de moradores discutia a sondagem sobre a "venda de lotes",

Como é que pode isso! Agora que as coisas estão melhorando, tem gente que já esqueceu como era carregar as coisas nas costas de lá da barreira até aqui, andava três dias com as coisa nas costa e hoje já tem energia e asfalto e vai dá assim de mão beijada. O quê que tá faltando? (Sr. N. A. V)

Percebe-se o aumento da pressão sobre os lotes após o asfaltamento do ramal Pau Rosa, em que se vê que pelo menos 50\% das parcelas do ramal se tornaram sítios de fim de semana, perdendo a característica essencial da agricultura (NEVES, 2011). Para o atual presidente da comunidade Pau Rosa, esses novos moradores fazem reivindicações consideradas absurdas quanto à infraestrutura local,

\footnotetext{
${ }^{8}$ Termo usado para indicar, por vezes, o estado de decomposição de certas rochas, no qual elas se acham semiagregadas, ex.: areia grosseira; outras vezes usa-se para designar o cascalho que aparece no solo. (GUERRA, 2008, p.483).
} 
Esse pessoal vem aqui comigo e qué que eu dê conta de ir atrás de meio fio, iluminação pública, esgoto e água encanada. Isso é coisa de cidade, se eles qué vivê como se tivesse na cidade porquê que veio pra cá? Se qué vivê assim, volta pra Manaus. Aqui não é cidade, a gente vive no mato, e no mato não tem muita coisa. A gente tem que dá graças a Deus que nóis tem isso aqui, tem comunidade aí que num tem metade do que nóis tem, a gente da roça tá acostumado com coisa pior que essa, aí vem um camarada da cidade e acha que ainda num tá bom, tem a mão lisinha nunca que pegô numa enxada e num teçado.

"Esse pessoal" é a designação do outro que não é um agricultor, portanto, não é "um igual". Por não serem agricultores suas reivindicações expressam suas necessidades de moradores da cidade como água encanada e saneamento básico. Por isso a indignação do presidente da associação, "se eles qué vivê como se tivesse na cidade porquê que veio pra cá?". Viver no mato implica conviver com dificuldades e buscar a resolução, "aqui não é cidade, a gente vive no mato, e no mato não tem muita coisa". Problemas para os camponeses não é a ausência de calçadas, mas o atraso das aulas por causa da estrada em más condições por conta das chuvas, por exemplo.

O assentamento é destinado para os agricultores. Recriar a vida do morador da cidade não é objetivo do campesinato, mas de quem procura transformar o lote em área de lazer. Por conseguinte, para quem não é do mato e não consegue viver sem os serviços urbanos não deveria sair da cidade.

Nesse sentido, a busca por melhorias básicas para os camponeses são burocráticas podendo levar anos para se conseguir. Enquanto isso, os donos de sítios pretendem fazer do lote a extensão de suas moradias com o padrão urbano em terra pública para a reforma agrária (foto 3), isto é, há terra-mercadoria num lugar em que não deveria existir. Oliveira (1986, p.76) explica que no modo capitalista de produção, o solo, a terra, embora não tenha valor, tem um preço. 
Foto 3 - Sítio de fim de semana.

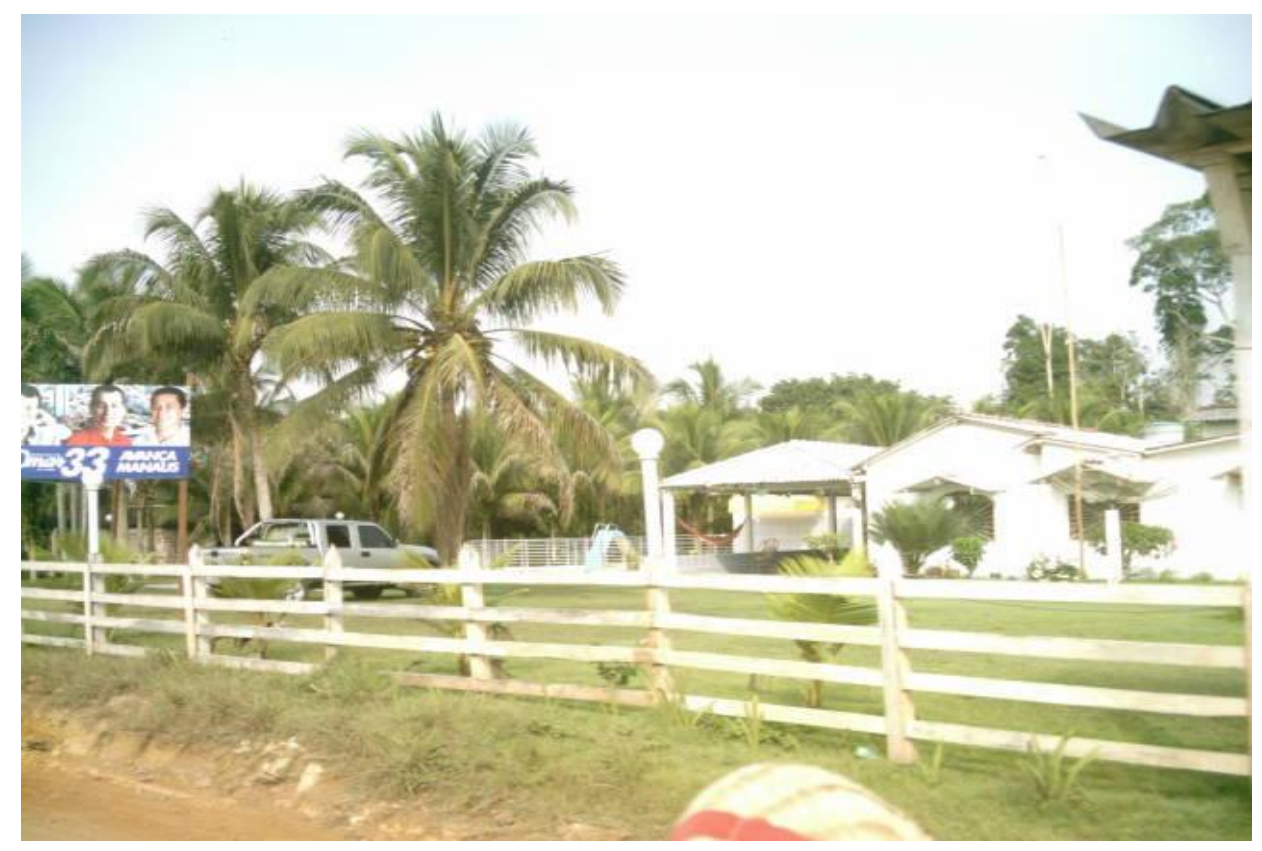

Fonte: Trabalho de campo, 2010-2012.

No entanto, a questão se torna contraditória pelo fato de se tratar de terra pública para reforma agrária na qual não poderia ocorrer a "venda dos lotes" (foto 4). Um cliente da reforma agrária, assim definido pelo Estado, receberia um ressarcimento pelas obras já realizadas no lote que são chamadas de benfeitorias.

A situação de transformação dos lotes em sítios para o lazer é encontrada, com maior intensidade no ramal do Pau Rosa, principalmente após asfaltamento. A situação de venda dos lotes é expressa no gráfico 2. Apesar da pressão imobiliária ainda é grande $(46 \%)$ a quantidade de camponeses, primeiros beneficiários é expressiva. 
Gráfico 2 - Condição de dono.

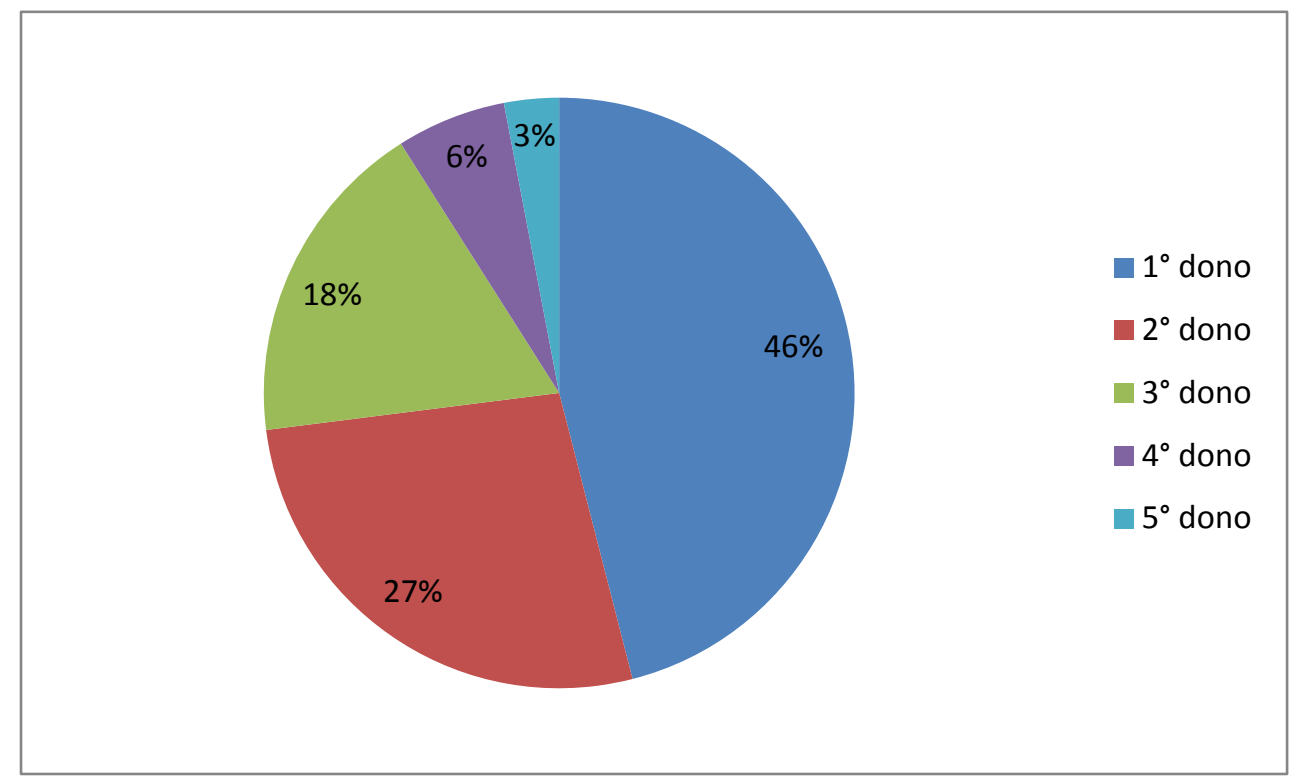

Fonte: Trabalho de campo, 2011-2012.

O primeiro dono, 46\% correspondem aos beneficiários do INCRA. Enquanto os demais, segundo, terceiro, quarto e quinto dono "compraram" de terceiros. É preciso ressaltar que a indenização pelas benfeitorias esconde o mercado de vendas dos lotes.

Foto 4 - Venda de lotes.

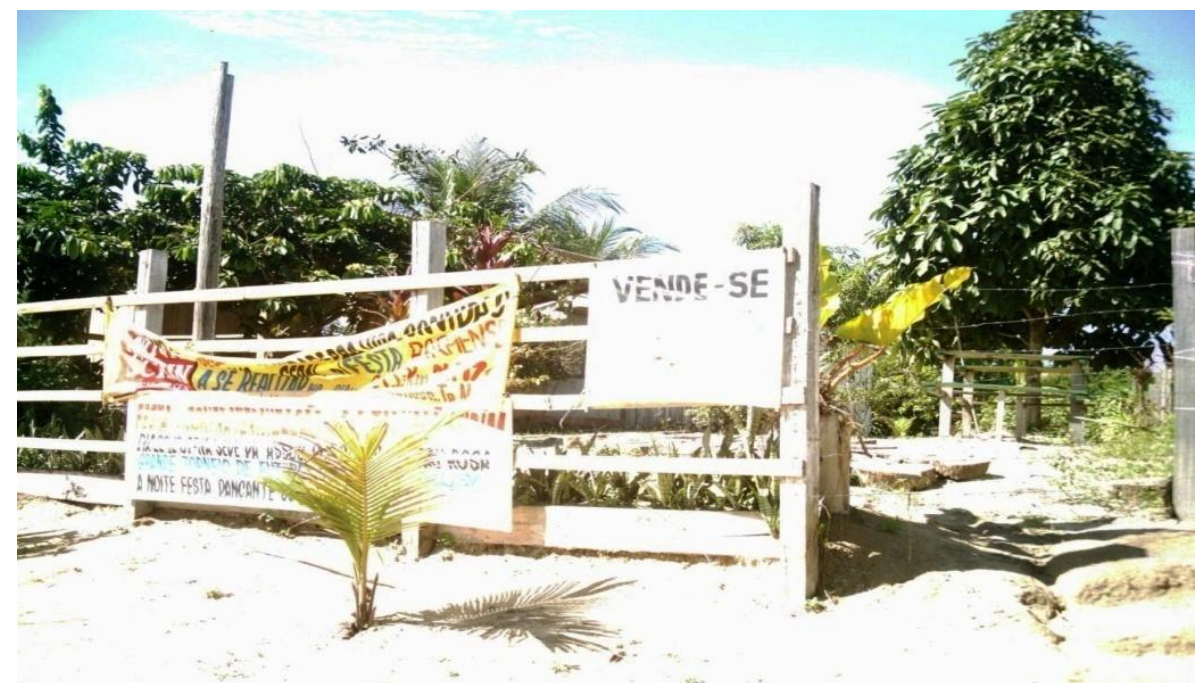

Fonte: Trabalho de campo 2010-2013.

A expansão da cidade já ultrapassou o que se convencionou chamar de perímetro urbano. O limite oficial da cidade era a barreira de fiscalização policial e de 
trânsito. A expansão urbana de Manaus está em direção da região do Tarumã e em consequência do assentamento há a pressão do preço da terra na comunidade Pau Rosa.

Segundo o Sr. Raul, chefe do setor de criação e desenvolvimento de assentamentos do INCRA, a especulação imobiliária com vistas a transformar lotes em áreas de lazer é uma tendência em assentamentos próximos a áreas urbanas. Por isso, haveria uma resistência em se criar projetos de assentamento próximos a grandes cidades. 


\title{
CAPÍTULO 3 - ETNOCONHECIMENTO, CULTURA E PLANTAS MEDICINAIS.
}

Os conhecimentos sobre o ambiente, caracterizado como etnoconhecimento camponês é o ponto principal deste capítulo. Pretende-se, desta forma, discutir como os camponeses, a partir do conhecimento acumulado durante gerações, fazem uso dos elementos da natureza para a resolução de problemas do cotidiano, principalmente os referentes à saúde.

Os trabalhos de Posey (1997, p.1) lançam as bases para os estudos sobre etnoconhecimento. Pois considera as várias dimensões que comportam os conhecimentos de grupos até pouco tempo menosprezados,

\begin{abstract}
O conhecimento indígena não se enquadra em categorias e subdivisões precisamente definidas como as que a biologia tenta, artificialmente, organizar. Ao invés disso, o conhecimento biológico de folck vem a ser um amálgama de plantas, animais, caçadas, horticultura, espíritos, mitos, reuniões, energias, cantos e danças. Assim sendo, os ciclos cerimoniais que incluem ritos específicos, em que determinados animais e plantas são representados nos cantos e danças, a fim de propiciar energia espiritual tendente a obter boas colheitas e caçadas profícuas - podem ser ordenados segundo sequências mitológicas.
\end{abstract}

Para tanto, é singular a domesticação de plantas da mata e seus respectivos usos em remédios. Com efeito, cascas, raízes, resinas, folhas, frutos, sementes possuem propriedades fitoquímicas essenciais para o preparo de xaropes, "garrafadas", comprimidos e chás. Pode-se afirmar que este etnoconhecimento faz parte de uma herança indígena (RIBEIRO, 1997, p.2),

[...] os grupos indígenas constituem hoje, os últimos repositórios vivos de um saber acumulado durante milênios para a sobrevivência humana na floresta tropical úmida, nos campos e cerrados. Parte dele foi herdado pelas populações rurais - caboclos, sertanejos, caipiras, caiçaras - encontrandose, em graus diversos, codificado nas culturas de folk.

O etnoconhecimento, no entanto, não se restringe às plantas medicinais. A escolha da roça, a construção da casa as espécies de plantas cultivadas nos quintais trazidas da mata para observar sua domesticação. A cotidianidade camponesa se realiza em sua completude com os saberes herdados. Leff (2007, p.169) enfatiza o saber ambiental, 
Propõe a questão da diversidade cultural no conhecimento da realidade, mas também o problema da apropriação de conhecimentos e saberes dentro de diferentes ordens culturais e identidades étnicas. O saber ambiental não só gera um conhecimento científico mais objetivo e abrangentes, mas também produz novas significações sociais, novas formas de subjetividade e de posicionamento ante o mundo. Trata-se de um saber que não escapa à questão do poder e à produção de sentidos civilizatórios. [...] emerge como um processo de revalorização das identidades culturais, das práticas tradicionais e dos processos produtivos das populações urbanas, camponesas e indígenas; oferece novas perspectivas para a reapropriação subjetiva da realidade; abre um diálogo entre conhecimento e saber no encontro do tradicional e do moderno. [...] reconhece as identidades dos povos, suas cosmologias e seus saberes tradicionais como parte de suas formas culturais de apropriação de seu patrimônio de recursos naturais.

Os procedimentos concernentes ao ciclo agrícola dependem dos saberes sobre o ambiente. Por isso para o campesinato a forma de trabalhar a terra é centrada na família. Para Diegues (2000, p. 30),

Conhecimento tradicional pode ser definido como o saber e o saber-fazer, a respeito do mundo natural e sobrenatural, gerados no âmbito da sociedade não urbano/industrial e transmitidos oralmente de geração em geração. Para muitas dessas sociedades, sobretudo as indígenas, existe uma interligação orgânica entre o mundo natural, o sobrenatural e a organização social. Nesse sentido, para estas últimas, não existe uma classificação dualista, uma linha divisória rígida entre o "natural" e o "social", mas sim um continuum entre ambos. [...] De certa maneira, ainda que em graus e qualificações distintas, o que foi explicitado para as populações tradicionais indígenas vale também para as não indígenas, como as ribeirinhas amazônicas, caiçaras e outras onde a influência da cultura indígena é importante.

Os saberes ambientais fazem parte do cabedal de conhecimentos dos povos tradicionais. O modo de vida dos camponeses é diretamente dependente do acesso aos recursos naturais (DIEGUES, 2000, p. 26). Seja para a retirada de madeira para a construção das benfeitorias, partes de plantas, seja para o preparo de remédios e para rituais. 


\title{
3.10 modo de vida camponês.
}

A natureza é elemento fundamental para o modo de vida camponês. O meio natural será apropriado conforme a cultura, assim definido por Antonio Candido (2001, p.36),

\begin{abstract}
O meio natural aparece de início como grande celeiro potencial, que não será utilizado indiferentemente, em bloco, mas conforme as possibilidades de operação do grupo; pois os animais e as plantas não constituem, em si, alimentos do ponto de vista da cultura e da sociedade. É o homem quem os cria como tais, na medida em que os reconhece, seleciona e define. O meio se torna deste modo um projeto humano nos dois sentidos da palavra: projeção do homem com suas necessidades e planejamento em função destas - aparecendo plenamente, segundo queria Marx, como uma construção da cultura.
\end{abstract}

Deste modo, portanto, a natureza representa a fonte do desenrolar da vida, as práticas culturais vão determinar seus respectivos usos. Em se tratando dos camponeses assentados, seus modos de vida estão ligados a vivências anteriores. A diversidade de moradias implica também intensa troca de conhecimento. Encontram-se na comunidade Pau Rosa, camponeses de diferentes estados da federação, conforme já assinalado. Há distinções de temperos, religiões, vocabulários. No entanto, a semelhança fundamental se refere à busca pela terra de trabalho com mão de obra familiar.

O acesso a terra não fica restrito meramente a uma relação econômica. A satisfação das necessidades da família remete a um contexto de ordem moral. Para Woortmann (1990, p.37), "[...] A troca entre os homens é a continuidade de troca com a natureza, pois é a troca de alimentos (que resultam da troca com a terra) e de trabalho (que constrói a terra e produz alimentos)". A legalidade da terra se dá por meio do trabalho, nesse sentido trabalhar a terra é tecer a vida,

Todo fio de Deus tem o direito de tê um pedacin de terra pra prantá, e criá os fio, ensiná tudo prá eles, pode num sê que vai sê rico, mais que de fome ninguém morre. E também num vira ladrão. Que se ocê vê bem, nóis aqui já é rico, que lugá do mundo tem terra, água, mata como que têm aqui? Só Deus prá dá tudo isso aqui pra gente. (Sr. J.S.S.)

A natureza, por ser dádiva de Deus, não pode ser apropriada privadamente por um pequeno número de pessoas enquanto a maioria dos que vivem dos frutos 
da terra vivem com dificuldades, por isso "todo fio de Deus tem direito a um pedacin de terra". Sustentar a família é o objetivo do campesinato e o modo de vida, por sua vez, se constituirá em função das estratégias culturais para a resolução dos problemas do cotidiano. Essa perspectiva é abordada por Candido (2001, p.29),

\begin{abstract}
A existência de todo grupo social pressupõe a obtenção de um equilíbrio relativo entre as necessidades e os recursos do meio físico, requerendo, da parte do grupo, soluções mais ou menos adequadas e completas, das quais depende a eficácia e a própria natureza daquele equilíbrio. As soluções, por sua vez, dependem da quantidade e qualidade das necessidades a serem satisfeitas. [...] Com efeito, as necessidades têm um duplo caráter natural e social, pois se a sua manifestação primária são impulsos orgânicos, a satisfação destes se dá por meio de iniciativas humanas, que vão-se complicando cada vez mais, e dependem do grupo para se configurar.
\end{abstract}

As relações sociais estabelecidas no interior da comunidade definem práticas de reciprocidade necessárias à boa convivência. Dentre estas se podem citar a abertura de "picadas" nos sítios sem acesso à estrada, a mobilização para fazer as hortas de família iniciantes na produção de hortaliças.

Estas práticas são necessárias para auxiliar as famílias a construírem sua infraestrutura produtiva, de modo a conseguir sua autonomia econômica. A ajuda mútua contribui para suprir a demanda por mão de obra nos sítios. Neste caso, porque os casais permanecem nos sítios, enquanto os filhos vão para Manaus estudar. Marques (2000, p.209) assim explica este processo,

\begin{abstract}
A sociabilidade no interior da comunidade é marcada pelo princípio de reciprocidade e pela adoção de práticas características do campesinato brasileiro como a trocas de dias, de serviços e de produtos e o mutirão. Estas formas de cooperação são realizadas sobretudo nos momentos de "precisão", observados seja nas atividades produtivas, seja na vida doméstica. A categoria "ajuda" expressa bem o significado que estas práticas têm para os "posseiros" de Retiro e Velho.
\end{abstract}

De acordo com os depoimentos colhidos, os comunitários estão subdivididos em pequenos grupos. Foi possível identificar a divisão por causa da religião (católicos e evangélicos), por vicinal (solidariedade maior entre vizinhos de sítio), pela amizade construída por causa da chegada à comunidade no mesmo período e enfrentado juntos as dificuldades.

Nas falas dos camponeses vê-se como preocupação central o bem estar da família. A estas características, no estudo de Woortmann (1990, p.12, 13) entendese a campesinidade, pois trata "de valores sociais: não do valor-trabalho, mas do 
trabalho enquanto valor ético", neste trabalho a família é um dos pontos centrais "a família como um valor, o valor-família, permanente no tempo".

A alimentação da família representa a boa administração do pai, mas, as terras da comunidade Pau Rosa não dispõem de fertilidade natural (RADAMBRASIL, 1970) o que explica o depoimento do Sr. R.S.

O nosso solo aqui dessa região é pobre, pra gente prantá de tudo. Dá uma coisinha aqui ôtra ali, mas é só, não dá os mais importante. Não dá o arroz, que é básico, a gente sem o arroz e o feijão não vive. Aqui chove muito, o solo é muito lavado e pra se tê arroz tem que queimá bem queimadinho, o feijão dá mais na bêra do rio. O milho já tentei prantá aqui, mais dá só umas bunequinha e num disinvolve. A gente tem de se virá de outro jeito. A farinha a gente tem de livrá, que pelo meno a farinha tem de dá. A despesa da comida a gente tinha de livrá. Agora dá até vergonha de falá prá sinhora que a gente compra arroz e feijão na rua.

As dificuldades encontradas no roçado estão associadas, em certos casos, a crises familiares no sítio. A ausência do pai, por motivo de doença, fez com que o sítio ficasse sem direção, pois é o pai quem escolhe o lugar da roça, o que, quando e onde vai ser plantado. É neste momento que o pai se realiza enquanto chefe de família, "tem o controle sobre a terra, o trabalho e o tempo". (WOORTMANN, 1990, p.44). Noutra situação, a morte de um filho deixou os pais desgostosos.

Tendo em vista os constantes impasses em desmatar, fazer o roçado e a fertilidade da terra os camponeses tiveram de se reinventar para conseguir produzir. É frustrante para os camponeses não conseguirem a autonomia e comprar o mínimo possível no mercado, o que eles não produzem.

$\mathrm{O}$ ato de "se virar de outro jeito" trata-se de trabalhar e vender aquilo que era destinado ao preparo de remédio e para "enganar a fome das crianças". As cascas e resinas são vendidas no sítio do Sr. R.S., enquanto as frutas serviam de distração para as crianças agora são comercializadas e até encomendadas aos camponeses.

Para os camponeses é motivo de vergonha não produzirem o suficiente para garantir a mesa farta. Isto quer dizer haver uma produção essencial para satisfazer as necessidades alimentares da família. Neste caso, a terra deveria produzir milho, arroz, feijão e mandioca.

O milho para alimentar os animais (a mistura que complementa a comida), a mandioca para produzir a farinha. O arroz e feijão para o consumo da família. Não foi encontrado quem cultivasse arroz e milho, apenas o feijão e a mandioca. Para as 
pequenas refeições ao longo do dia tem os pomares. Árvores frutíferas, frutas e legumes são cultivados nos quintais, próximos a casa (foto 5, 6 e 7).

Foto 5 - Leira de cebolinha de palha.

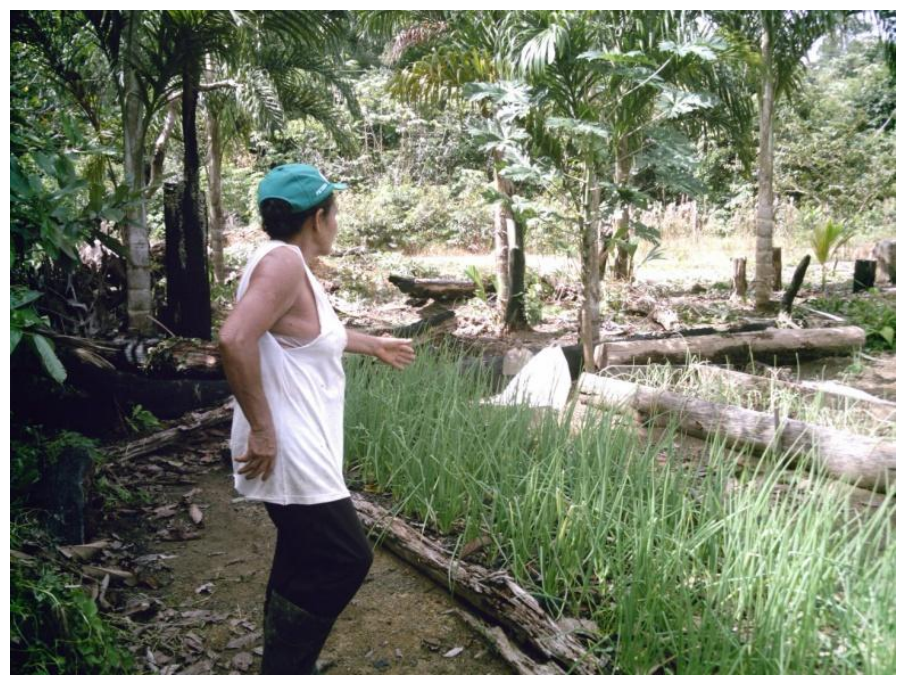

Foto 6 - Cubiu.

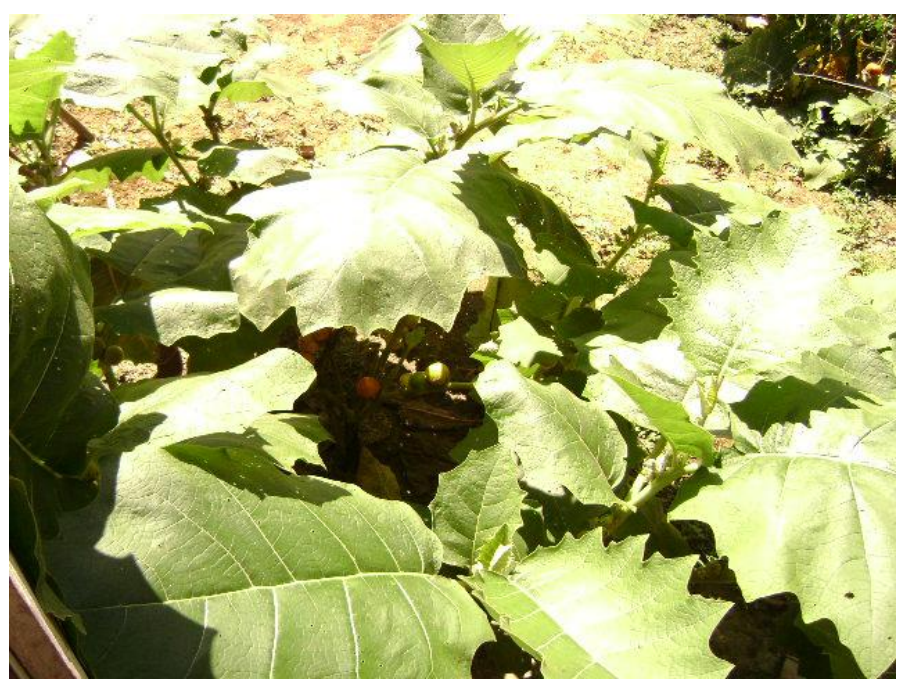

Foto 7 - Leira de coentro.

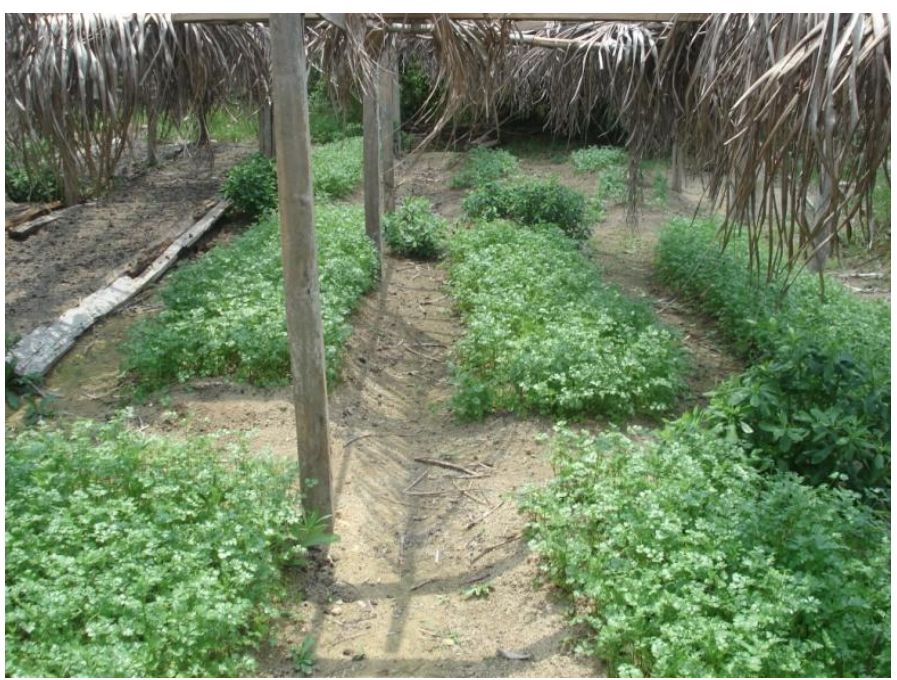

Fonte: Trabalho de campo, 2010-2012.

A cebola de palha, coentro e a chicória integram o "cheiro verde" e são cultivados em leiras diretamente no chão e no período de maior calor podem se ter uma cobertura de palha ou plástico para evitar que queimem com a intensa radiação solar. O cubiu substitui o tomate na salada e por ter um sabor amargo é utilizado como remédio para tratamento de malária.

Apesar de nos depoimentos ser recorrente a afirmação de infertilidade do solo se verifica a diversidade de cultivares. Quando os camponeses são perguntados se 
criam animais e se têm roças a resposta é não, sendo comum ouvir "tem umas coisinha aí prantado" mas, quando nos mostram o sítio percebem-se animais, patos, galinhas, em torno da casa e espécies plantadas, variedades frutíferas, leguminosas nas hortas e a roça de mandioca, comum em todos os sítios visitados.

Foto 8 - "Criaçãozinha" de patos.

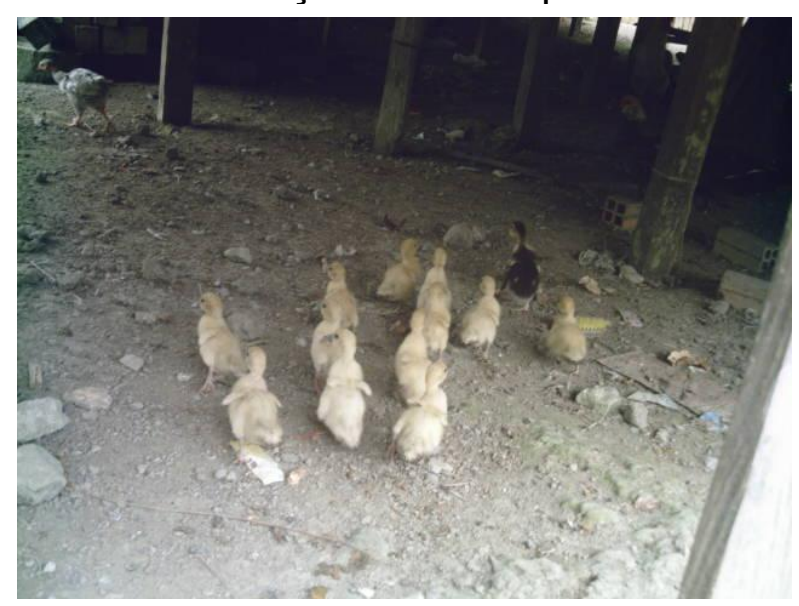

Foto 9 - "Uns porquinhos por aí, nada de muito".

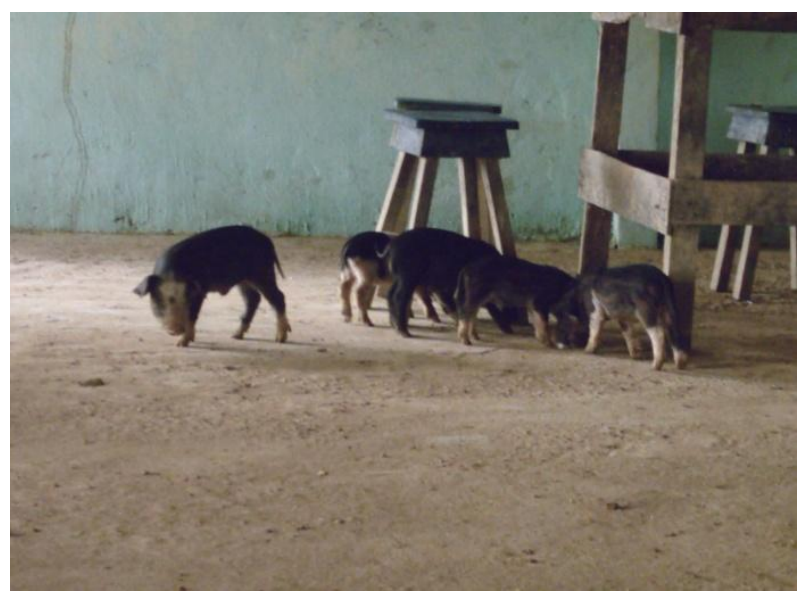

Fonte: Trabalho de campo, 2010-2012.

As "coisinha" representam o que Bombardi (2004, p.153) identificou em seu trabalho como "pro gasto". A expressão utilizada no diminutivo designa a visão camponesa acerca do que possui a alimentação, são "coisinhas" porque é pouco se considerado o necessário para o consumo doméstico e para levar à feira. Apesar de suprir a demanda alimentar ser de grande importância, contudo, não há o contentamento com a quantidade.

O uso equilibrado dos elementos da natureza perpassa valores morais. Desmatar desenfreadamente, matar animais de caça e não consumi-los, pode despertar a ira dos seres protetoras da natureza, dentre os citados em depoimentos estão, mãe natureza, mãe d'água, curupira, juma e o boto. Estas criaturas podem afastar as caças, influenciar em colheitas ruins, desorientar as pessoas na mata e mesmo adoecer os transgressores das "leis da natureza",

A gente num pode caçá prá estragá, tem que ir atrás só do de comê. Se a gente bagunçá no meio do mato a mãe natureza vem atrás. Eu tenho um tio que fez a maió zoera no mato, matô um monte de caça só pra estragá, bebeu a pinga e pegô o fumo da caipora, e ainda falô pra eles (seres) vim atrás. Isso foi lá no Maranhão, pensa num cabra que num respeitava nada, ele, até que um dia ele levou uma pisa do 
curupira, aí nunca mais ele se engraçou de pertubá a mata, a mata é viva. Aí a gente veio pro Amazonas, e nunca mais ele se meteu a brincá com coisa séria, onde tem mato a mãe natureza repara ele, quando dá seis hora (18:00h) ele num vai tomá banho no rio de jeito nenhum. Se ele se esquece de tomá banho e vê que tá escurecendo ele dorme sujo mermo, antes de noitecê ele já vai quietinho caça a rede dele. Quem vai caçá num leva o tio que onde que ele tá as caça foge tudo. (Sr. S. V)

A relação entre os grupos sociais e a natureza deve ser de respeito. Disto, depreende-se a mata como uma entidade viva e com procedimentos a serem cumpridos para o perfeito estabelecimento de uma ordem natural. No depoimento, é narrada a incredulidade de um parente com os seres responsáveis pelo equilíbrio da natureza, matou caça, estragou alimento, desacreditando na punição para os seus atos, bebeu a pinga e fumou o cigarro da caipora.

O fato ocorreu no estado do Maranhão e a mudança para o Amazonas não encerrou as punições, onde tem mata o tio do Sr. S. V. é vigiado pela mãe natureza, não pode tomar banho após as $18 \mathrm{~h}$ por causa da mãe d'água, nem mesmo andar sozinho na mata, foi impedido também de acompanhar os homens para a caça, ele está "encantado" por ter infringido as normas de matar a caça o suficiente para se alimentar. 


\subsection{A moral camponesa.}

A terra de trabalho é para o camponês a razão de ser de sua luta. Após adquirir o seu pedaço de terra é preciso honrar sua condição de agricultor. A esta honra, o camponês se refere à territorialização do trabalho, fazer as roças, atendendo às necessidades do sítio.

Nestes termos, quem tem terra e não a trabalha, não cumpre a sua função de produzir alimentos, portanto, não a merece. Neste caso, deve ser repassada para quem de fato necessite e se disponha a plantar, no caso, as famílias de sem terra. É visto com ressalvas aqueles que possuem muitas terras, chamado pejorativamente de "fazendeiro".

A figura do fazendeiro é encarada, simbolicamente, como a do grande proprietário que para se garantir como tal, expropria e/ou explora os "pequenos agricultores". Nesta ótica camponesa, o tamanho da terra, propriedade, varia em conformidade com o tamanho da família. Mais uma razão para o fazendeiro ser encarado como desleal. Porque, tendo uma família pequena, não há mão de obra suficiente para trabalhar a terra, precisando para tanto, assalariar.

Geralmente se dedicar integralmente à pecuária ou a alguma monocultura, desvirtua a terra de sua característica essencial de produção de alimentos. Por isso, o fazendeiro é encarado como contraditório porque precisa se alimentar e se recusa a produzir alimentos que atendam às necessidades da família.

Produzir remete especificamente a quem produz os alimentos, faz o roçado. Quem produz é o agricultor, o camponês. O ato de produzir garante o sustento da família e para a venda ao mercado. Quando ocorre algum imprevisto "tem que se livrar ao menos o de casa", isto é, garante-se num primeiro momento, a alimentação e depois se preocupa em vender.

Para o fazendeiro, a lógica é exatamente o contrário: o lucro justifica sua existência, mesmo que para conseguir isso, num primeiro momento, sacrifique a família, para futuramente satisfazer as necessidades de consumo, porque com o dinheiro se compra "tudo". Nesse sentido, para "o fazendeiro" se manter como tal é preciso grilar terra pública e expropriar camponeses.

A expropriação sucessiva é determinante para a formação de pobreza no campo, e a procura por novas terras segue uma ordem moral na qual a terra, por ser dádiva de Deus, deve ser partilhada por todos. Na obra Costumes em comum, 
Thompson (1998, p.152) retrata a miséria à qual a população inglesa é submetida por causa das práticas utilizadas no mercado para o comércio dos cereais. Desse modo, motins se instauraram para impedir que a produção agrícola fosse exportada deixando a população local sem alimentos.

Em certos casos, saques foram realizados, no entanto, a prática predominante foi de pegar à força a produção e pagar o que seria justo.

\begin{abstract}
O motim da fome na Inglaterra do século XVIII era uma forma altamente complexa de ação popular direta, disciplinada e com objetivos claros. [...] É certamente verdade que os motins eram provocados pelo aumento dos preços, por maus procedimentos dos comerciantes ou pela fome. Mas essas queixas operavam dentro de um consenso popular do que eram práticas legítimas e ilegítimas na atividade do mercado e dos moleiros que faziam o pão etc. Isto, por sua vez, tinha como fundamento uma visão consistente tradicional das normas e obrigações sociais, das funções econômicas peculiares a vários grupos na comunidade, as quais, consideradas em conjunto, podemos dizer que constituem a economia moral dos pobres. O desrespeito a esses pressupostos morais, tanto quanto a privação real, era o motivo real para a ação direta. (THOMPSON, 1998, p.152)
\end{abstract}

Tal costume pode ser explicado a partir de uma ordem moral que rege a vida na comunidade, sendo, portanto, a manutenção da família o objetivo das ações. Isto explica a posse, neste contexto, uma ação juridicamente ilegal, mas injusta.

Nesse sentido, na perspectiva camponesa, o fazendeiro (latifundiário) não precisa de tanta terra, mas a ganância de uns desencadeia a pobreza de muitos. Esta postura para os camponeses é uma aberração porque é preciso assegurar o necessário, a alimentação e abrigo da família, para em seguida, adquirir eletrodomésticos.

Em observações nos trabalhos de campo, foi possível identificar o uso pejorativo do termo fazendeiro por camponeses.

Sr. A. B. L: esse aqui é o fazendêro aqui da região.

Sr. J. C. S: dêxa disso, Deus me livre ser fazendêro.

O Sr. J. C. S. é o camponês de melhor situação econômica e em tom de brincadeira era chamado de fazendeiro, no entanto, isto soava como ofensa. Logo, em seguida foi explicado que o Sr. J. C. S. era independente e não precisava do governo para ter estabilidade econômica, ele é um "forte". A discussão relativa à 
diferenciação econômica é feita por Bombardi (2004, p.276) no estudo sobre o Bairro Reforma Agrária,

[...] A comercialização de seus produtos e a transformação de alguns sitiantes em pequenos capitalistas, pela via da comercialização dos produtos de outrem, faz com que haja no Bairro um processo de diferenciação social, indicando por meio da expressão "os fortes".

Os sitiantes "fortes", sejam eles pequenos capitalistas ou camponeses ricos, são tão integrados ao bairro rural quanto os demais. $O$ processo de socialização é o mesmo, o convívio é o mesmo. Estas famílias procuram formas de reproduzirem-se na terra por meio da aquisição de outros sítios, de preferência no próprio Bairro, para a "irmandade".

O "forte" é considerado o de "melhor condição" e por isso troca dias de serviço ou paga diárias a outros camponeses, "ajudando" os mais fracos e complementando a mão de obra da família. Ajuda-se aquele que está em momento de "precisão", para que este, momentaneamente fraco também possa se tornar um forte, estabelecendo-se uma relação entre iguais.

Situação diferente é a do individual. Este é denominado como o investidor, "compra" o lote de alguém e não vive do que produz. Em geral é um assalariado da cidade ou funcionário público, trabalha em Manaus e paga um caseiro para vigiar o lote e alimentar animais, se for o caso. Outros serviços como a limpeza de alguma área, plantio de cultivares, construção de cercas, consertos em geral são pagos fora e à parte do salário. A forma de pagamento pode ser em diárias ou pela empreita.

Os individuais dificilmente constroem laços de solidariedade com os camponeses, visto sua vida se realizar na cidade, desconhecendo a natureza local,

Chegô um rapaz ali na Cooperativa (comunidade), ali onde tem aquela armação de prástico sabe? Aquilo lá o povo do IDAM disse que é prasticultura, é caro pra daná. Os fraco como nóis aqui num tem bala na aguia prá fazê um troço daquele. Ele tentô prantá pimentão. Só de oiá ali já sabia que ia dá errado, ele dismató muito ali do lado. Aqui se tirá uma arvinha faz farta. Aqui já é quente e se dismata muito, fica pió! Ainda mais o pimentão, ele é muito melindroso, tem que tê a lua certa, se num fô, desanda tudo. Taí, o que num virô meleca deu praga. Se ele tivesse se chegado aqui cum nóis a gente tinha falado como que ele tinha de fazê, se a gente fosse lá metê o bedeio ia chamá a gente de abeiudo. (Sr. O. C. D)

O depoimento revela a relação entre "fracos" e "individuais". O individual pode arcar com o custo de utilizações de técnicas como a plasticultura, no entanto, 
investir capital não é suficiente para o sucesso na produção. Os fracos, no entanto, apesar de não possuir dinheiro suficiente para implantar técnicas onerosas, "num tem bala na aguia prá fazê um troço daquele", contam com os conhecimentos adquiridos dos ciclos da natureza para direcionar suas atividades.

Por isso, observando, os camponeses identificavam as falhas e quais seriam os resultados, "Aqui se tirá uma arvinha faz farta. Aqui já é quente e se dismata muito, fica pió! Ainda mais o pimentão, ele é muito melindroso, tem que tê a lua certa, se num fô, desanda tudo". A falta de conhecimento da natureza e sem vínculos com os camponeses, a produção de pimentão do individual não prosperou, "o que num virô meleca deu praga".

Mas, se ao invés de confiar somente na técnica "o individual" fosse pedir conselhos aos camponeses mais antigos no assentamento, saberia os procedimentos a adotar para o cultivo do pimentão, evitando o prejuízo "Se ele tivesse se chegado aqui cum nóis a gente tinha falado como que ele tinha de fazê".

O camponês expõe sua opinião quando é procurado, em geral por um conhecido, caso contrário teme ser encarado como um intrometido "se a gente fosse lá metê o bedeio ia chamá a gente de abeiudo". Nas sociedades camponesas existem as trocas de informações, todos sabem o que seus conhecidos estão plantando, onde estão localizadas as roças, se vão à Manaus e quando voltam. Esta prática permite que os compadres cuidem do sítio de quem está ausente. 


\subsection{0 tempo para plantar.}

Ao conversar com os camponeses e perguntar o que eles plantam, é comum a resposta ser, que naquele momento, não estão plantando nada ainda, seja pela falta dos filhos para ajudar, problema de doença na família. No entanto, quando nos convidam para ver "o pouco que prantaram", percebemos que há uma diversidade de plantas no pomar, as retiradas da mata e as hortas, que representam a principal fonte de renda porque são comercializadas nas feiras.

Em geral há um descontentamento em virtude da impossibilidade de ter toda a área do sítio com algum "serviço", isto é, com roçados tão variados que não haja necessidade de comprar gêneros alimentícios na cidade. Mas, nos mostrar o que tem plantado é como se estivessem justificando estar cumprindo a "tar da função sociar" e o fato de tirar fotos era a comprovação de haver trabalho no sítio. Isto ocorreu com a primeira família visitada.

Pode oiá tudo aqui, olha só aqui tem guaraná, graviola, laranja, ingá,
abacate, manga, tangerina, cupuaçu, tem prantado a mandioca, mio
(milho) é a primeira veiz que tô prantando mio aqui, num sei se vai dá
certo, essa terra aqui num é muito boa. Sabe tá assim sujo porque eu
fiquei doente e agora vem eles aqui (INCRA) e diz que vai tirá meu
lote, dizendo que num tamo cumprindo a tar da função sociar"? Só
fartô me chamá de priguiçoso, aí ele vê, levá uma lapada de teçado,
ninguém perguntô o que aconteceu comigo nesse tempo, eu sô um
dos primero que chegou aqui, daí eu peguei um derrame que fiquei
com esse lado aqui (mostrando o lado esquerdo) todo paralisado, caí
lá na roça de mandioca, e essa é a mais longe que tem, fica lá no
fundão do sítio. Os médico disenganarum, falarum que num tinha
mais jeito, que ia morrê aí a muié cuidô de mim fazendo chá e banho
que a véia mãe dela ensinô e que ela aprendeu por aí. Mais Deus é
maió que tudo, hoje tô aqui como a senhora pode vê e esses dia já
vô arrumá a casa, mudá de lugá (aponta para onde será construída a
nova casa), já posso morrê, já tenho o que dexá pros meu menino.
(Sr. R.S.)

A enfermidade do pai e os filhos pequenos fazem com que a família passe por um momento de crise. Limpar ao redor da casa e mostrar o que tem plantado representa o esforço de alguém doente, pois se tratava do quarto avc, e a incompreensão do órgão gestor quanto ao uso do lote.

Prefere-se iniciar os plantios no mês de novembro no chamado "tempo das águas”, pois facilita a irrigação necessária para o desenvolvimento das plantas. No 
caso das hortas, plantar na estação seca demanda mais trabalho, é preciso aguar duas vezes ao dia. Uma vez ao amanhecer e outra ao entardecer.

O clima da região apresenta temperaturas elevadas constantemente, apresentando médias anuais de $27^{\circ} \mathrm{C}$ e $2.300 \mathrm{~mm}$ anuais. Há um período chuvoso de novembro a junho (inverno amazônico) e um período seco de julho a outubro (verão amazônico), PROAMBIENTE (2002) citado por Costa et. al. (2012, p.15 e 16).

Já as roças obedecem à chegada do inverno amazônico, é aconselhável iniciar o plantio direto a partir da terceira chuva seguida. Pois, no fim de outubro já iniciam as primeiras chuvas de inverno, nesse momento não deve se iniciar o cultivo porque há o risco de se perder mudas, trabalho e tempo. Um erro na data pode comprometer a roça para o ano seguinte,

\begin{abstract}
O ano agrícola é a grande e decisiva unidade de tempo, que define a orientação da vida do caipira, ao definir as suas possibilidades e empecilhos econômicos, e ao marcar a direção do ano seguinte. Ao longo dele se ordenam os seus trabalhos, cujas etapas são pautadas pelas operações agrícolas. Estas obedecem ao ciclo vegetativo e ao ajuste da planta às condições meteorológicas. (CANDIDO, 2001, p.157)
\end{abstract}

As fases da lua atuam de forma mais incisiva no desenvolvimento das hortaliças, como percebido no depoimento.

Mais aí se ocê ficá na dúvida da lua, é só prantá na lua nova, na
nova tudo fica bem ajeitadim, renova. Já pra pegá filho é bom a lua
cheia e pro cabelo, aí vai do que cê qué, se qué o cabelo mais
grosso aí tem que cortá na cheia. Se mexê com horta na cheia, tudo
fica cheio, té o mato fica ruim de limpá. A lua aqui é mais importante,
que aqui o clima é assim todo tempo. Hoje o povo que tem dinheiro
num liga pra isso, tem os pessoal que estuda pra isso, fala que isso
de vê a lua, num comê comida remosa é lenda, que a gente põe
essa coisa na cabeça aí acontece. Mais eu acho que isso é coisa de
quem qué sabê mais que Deus. A gente sempre viveu assim e dá
certo, e tá todo mundo vivo até hoje, esse povo da cidade já inventa
moda. (Sra. A. N. A.)

Caminhando pelo sítio é possível observar algumas espécies e a relação estabelecida com as fases da lua.

A cebolinha cê tem de prantá na crescente, se prantá na cheia aí enche de praga, a água fica na raiz e vira uma melequeira, aí tem que limpá e prantá tudo de novo. Coentro e sarsinha tem de prantá na cheia, que é pra eles ficá assim, igual toceira. Já vi gente dizê que 
isso é lenda, esse negócio de lua, mais é verdade, se ocê num segue o tempo das pranta cê perde trabaio. (Sra. M. V.)

Já o clima aqui se parece o ano todo. Num é como notros lugá que o clima é separadim. Aqui chove, num é brincadera, tem um verãozinho, mais no verão tamém chove. Mais aí a gente costuma né? Pra gente vê o que vai dá certo tem de prantá, se num prantá a gente nunca descobre. Se o caboco vem de fora tem de preguntá pros mais antigo como que faz, né? Aí já vai direto no que dá certo. (Sr. J. A. M.)

A observação e a sensibilidade para reconhecer as fases da lua e as transformações nas plantas e nas pessoas são características do modo de vida camponês. "Os pessoal que estuda" busca a cientificidade, seguir as fases da lua, evitar alimentos remosos são vistos como invenções de um imaginário popular.

No entanto, a religiosidade e o saber ambiental marcam um conjunto de práticas seguidas por várias gerações sem prejuízos aos grupos "a gente sempre viveu assim e dá certo", portanto, quem desqualifica o fato de obedecer a esses ritos, julga-se superior "qué sabê mais que Deus". Mas, "os pessoal da cidade" encaram estas peculiaridades com descrédito, típico de quem menospreza os saberes e ignora a valoração simbólica das práticas camponesas.

O trabalho no sítio é regido pelos conhecimentos das condições naturais. No caso dos camponeses migrantes há uma observação constante do ambiente e a pesquisa com os mais antigos no lugar a fim de evitar fracassos. Em trabalho de campo, perguntamos a uma senhora qual o melhor período para plantar, que nos respondeu:

...sabe, é melhor no tempo das água assim tem menos trabalho, entendeu? É que se a gente plantar no tempo da seca vai ter que aguar mais e se num tiver água perto? Aí vai ter de carregar e como nós estamos só em dois (ela e o marido) não dá pra ficar tanto tempo só aguando se não as verdura queima, a gente estamos plantando de tudo sabe, é até vergonha dizer que estamos comprado as coisa na cidade, da próxima vez que ocê vier aqui já vai provar da minha farinha e vai sê das melhor por aqui. (Sra. R. F. T.)

Por causa do clima e da falta de fertilidade natural, os camponeses afirmam não conseguirem fazer grandes roças como antigamente. O tempo antigo aparece como um ideal de felicidade propiciado pela fartura de antes e as dificuldades de agora, em um lugar que não foi possível ficar, assim verificamos nesta fala, 
Aqui num é como na terra do meu pai (Pará) lá a gente fazia roça de dá gosto, era uma lindeza só. A gente fez uma roça de mio [milho] e macaxeira que era assim, de um lado era pra gente tratá dos bicho e se aparecesse arguém prá comprá a gente vendia, mas só um pouco, que a gente num podia ficá sem. Já do outro lado era mio e macaxera pra dá pros cumpadre e conhecido. Me alembro duma vez que a gente tirô o mio nosso e só ficô só os do conhecido, aí veio um dono de lanchonete da rua mandô um recado pro meu pai se ele vendia o mio. Aí meu pai ficô brabro e mandou o rapaz vortá no memo rastro, que se ele quisesse vendê já tinha vendido. Aqui a gente faz roça mais num é como lá, é uma rocinha que num dá pra gente dá pra todo mundo que vem aqui, a gente dá mais é menos (Sra. M. L. S.).

Tendo em vista que na comunidade do Pau Rosa a produção é direcionada para o cultivo de hortaliças, e que a maioria dos lotes são habitados por um casal, é necessário dinamizar ao máximo a produção para que duas pessoas consigam dar conta do serviço. Os filhos ajudam os pais nos fins de semana, nos outros dias estão em Manaus trabalhando ou estudando.

Os jovens foram para Manaus estudar porque a escola municipal Neusa dos Santos, na comunidade Pau Rosa, oferecia somente o ensino fundamental. Para cursar o ensino médio era preciso ir morar com um parente na cidade e nos fins de semana retornam para o sítio. No trabalho de campo realizado em novembro de 2012, me foi relatado haver iniciado aulas de ensino médio, chamado de ensino tecnológico, no horário noturno na referida escola, são vídeo aulas mediadas por um professor.

Quando os filhos dos camponeses se assalariavam na cidade, isto se devia a uma crise na família, os pais permaneciam no sítio e contavam com a ajuda financeira dos filhos. Em um dos casos foi relatado que até a família se "aprumá" os filhos tiveram de trabalhar em fábricas do distrito industrial em Manaus, e ao melhorar a situação o pai iria construir quatro casas, uma para cada filho, estes com famílias já constituídas necessitavam de suas próprias moradias. 
3.4Estágios de sucessão ecológica e as plantas medicinais.

O lote, legalmente, não pode ser desmatado mais de duas quadras ${ }^{9}$ ( 2 hectares) para a construção das benfeitorias ${ }^{10}$. Conforme é efetuado o uso do solo pode-se aumentar a área desmatada, isso se estiver ocupando as duas quadras e seja necessário aumentar o seu cultivo, com a autorização dos institutos governamentais responsáveis isso é permitido.

Esse fato ocorreu com um dos entrevistados. Com o casamento de um dos filhos era necessário o desmate de mais uma quadra ( 1 hectare), como as duas quadras permitidas por lei já estavam sendo utilizadas, o filho precisava de mais uma quadra para iniciar seu próprio cultivo, após a visita de um técnico do IBAMA foi liberado mais um hectare.

Eu disafio, quarqué um que quisé me murtá, eu sô é agricutô, e como que o meu minino vai dá de comê para muié dele se num tivé um roçado dele memo e se ela ficá lógo barriguda? Sabe o que eu fiz? (ele ri) falei pro meu minino desmatá e comprei um tambaqui e chamei o teco (técnico) do IBAMA pra vim armoçá comigo e fiz questão de mostrá, aí ele disse que num tinha probrema se era pra prantá pra comê. Aí eles fizerum os paper e num tive probrema. (Sr. E.D.)

O pai com sua roça questiona o fato das imposições da legislação restringirem a área do roçado de tal forma que impede seu filho de formar sua família e, também formar sua própria roça. Na possibilidade de aumento da família do filho a situação se agrava, é preciso sustentar os filhos do jovem casal.

No entendimento de uma ordem moral, ser um agricultor os habilita a desmatar, por que para produzir alimentos é preciso desmatar e plantar, quando há o surgimento de uma nova família, a do filho, isto demanda um aumento da área de roça e a legitimidade em garantir o sustento da família, por isso a expressão "eu disafio, quarqué um que quisé me murtá, eu sô é agricutô”.

\footnotetext{
${ }^{9}$ Para os camponeses dessa localidade uma quadra é equivalente a um hectare e um alqueire corresponde a um hectare e meio.

${ }^{10}$ Entende-se por benfeitorias a casa, poço, galinheiro, pasto, ou seja, a infraestrutura necessária para a vida no sítio. No caso repassar o sítio a outra pessoa não ocorre a "venda" do lote, mas o pagamento pelas benfeitorias.
} 
O campesinato costuma estabelecer uma relação de amizade com os representantes do poder público, os técnicos do IBAMA, representantes do INCRA. Oferecer um almoço, presentear com frutas, hortaliças, galinha caipira, pato, porco, peixe, enfim, é a forma de estabelecer laços, mesmo que a relação não seja recíproca, o técnico poderia aplicar uma multa.

Assim, o camponês assentado está utilizando a área que legalmente é destinada ao plantio e na pretensão de aumentar a área de cultivo deve-se requerer uma licença junto à instituição pública responsável (IBAMA - Instituto Brasileiro de Recursos Naturais Renováveis, IPAAM - Instituto de Proteção Ambiental do Estado do Amazonas).

Estas licenças são um entrave para fazer as "derrubadas" implicando na escolha das áreas para as roças. São comuns as reclamações sobre a burocracia enfrentada para se fazer o pedido e obter a resposta das licenças. $O$ fato de $O$ Tarumã Mirim ter sido conhecido como o "assentamento do carvão" recai-se sobre os camponeses com preconceito.

Antes da existência das associações de produtores, o PA Tarumã era conhecido como o assentamento do carvão (OECO, 2008). Os camponeses afirmavam que não houve um assentamento, mas um "jogamento", porque o INCRA selecionou as famílias e as "jogou" sem a mínima infraestrutura, deixando-as a sua própria sorte.

Os camponeses tiveram acesso a terra, mas não às condições para trabalhar, num primeiro momento produziam o carvão, pois sem estradas e meios de transporte adequados não conseguiam levar sua produção para o mercado. Enquanto, o comprador do carvão buscava a produção diretamente no lote, apesar das péssimas condições das estradas vicinais. Os assentados que dependiam exclusivamente do governo eram os potenciais produtores de carvão (SOUZA, 2009).

A produção de carvão foi a estratégia encontrada para permanecer no lote em épocas de dificuldade financeira, no entanto, o apoio da Secretaria de Estado da Produção Rural (SEPROR) à associação de produtores ASSAGRI estava condicionada ao abandono das atividades relacionadas ao carvão. Com a ASSAGRI os camponeses produtores de carvão passaram a produtores de hortaliças e plantas medicinais. 
A diversidade de ambientes garante diversos usos desses espaços, de modo que as áreas de mata nativa, vegetação secundária (capoeira, capoeirão e capoeirinha) são necessários para o equilíbrio ecodinâmico de espécies (TRICART, 1977) bem como a existência em maior ou menor diversidade de plantas para o consumo. Visto que, com a floresta em pé é possível fazer uso das plantas, como cipós, raízes, cascas, resinas, seiva, óleo, para fins medicinais e para a venda.

Um dos entrevistados considerou a capoeira como um medidor de descaso com a terra em comparação com a mata nativa ou cultivada. Pois, há casos em que uma área é desmatada visando somente à retirada de madeira e não é feito nenhum "serviço", então cresce a capoeira e na área abandonada não é realizado nenhum trabalho, seja a construção de moradia, pasto ou roçado.

Considerando a dificuldade em limpar uma área de capoeira e as espécies que a compõem, os camponeses não aprovam desmatar sem o objetivo de plantar:

Quando a gente 'toroca' (desmatar) e num fáiz nada a mata castiga a gente, é milhó torocá a mata virge do que a capoeira. Na capoeira aparece tudo que num presta, é tiririca, cipó titica, rabo de camalião, esses capim tudo que corta, se a gente for pagá diária, os menino que limpá qué $R \$ 150,00$ conto se fô mata virge, se fô capoera eles qué $R \$ 300,00$ conto. A gente num pode tá pagando direto pra limpá e eles tem o serviço no sítio deles pra fazê, num pode tá dexando as coisa deles abandonada pra trabaiá pros outro. (Sr. G. A. P.).

Os diferentes estágios de sucessão ecológica não apresentam uma uniformidade em biodiversidade como afirma Rizzini (1997:347)

Se as condições o permitirem [no caso da capoeira], chega-se à mata secundária, cujo aspecto pode se igualar ao da mata primitiva, mas nunca a composição. [...] A tendência geral da sucessão é o sentido da simplicidade para a complexidade de organização e da dominância de formas de vida cada vez mais elevadas e variadas. [Inserções minhas].

É preciso ressaltar, no entanto, a importância dos grupos humanos na formação da biodiversidade, como destaca Diegues (1999, p. 3),

A biodiversidade não é simplesmente um produto da natureza, mas em muitos casos, é produto das sociedades e culturas humanas, em particular, das sociedades tradicionais não-industriais. [...] ela é também uma construção cultural e social. As espécies vegetais e animais são objetos de conhecimento, de domesticação e uso, fonte de inspiração para mitos e rituais das sociedades tradicionais e, finalmente, mercadoria para as sociedades modernas. 
As alturas das plantas, em diferentes estágios sucessionais, recebem denominações específicas, de acordo com os camponeses, são as seguintes:

Capoeirinha - estágio sucessional em que as espécies são de pequeno porte (menos de 1 metro) ocorre quando a área é desmatada e em seguida não é utilizada. De acordo com o Manual Técnico de Vegetação do IBGE (1992:32) "refere-se ao que o povo denomina de "capoeirinha". Esse estágio sucessional secundário apresenta graminóides" que são denominadas de capoeirinha como sendo "os primeiro matinho que nasce quando derriba a mata, nóis fáis o roçado e quando colhe se num prantá a capoeirinha toma de conta e fica pió de prantá".

Capoeira - se trata do estágio em que a capoeirinha alcança um porte médio (1 a 5 metros). Para Rizzini (1997:347),

Derrubada à floresta primária, a tendência é a reconstituição, visto o solo não estar inteiramente degradado e haver sementes nas circunvizinhanças. Assim, as próprias plantas da floresta, acrescidas de espécies heliófilas vulgares, constituem uma matinha fina conhecida como capoeira" (RIZZINI, 1997, p.347).

Para Miranda (2007) a capoeira é a "vegetação secundária que nasce após a derrubada das florestas virgens. Mato que foi roçado, mato que substitui a mata secular derrubada".

Capoeirão - Estágio em que a capoeira apresenta semelhanças com a mata primária. Rizzini (1997) afirma que a capoeira, imperturbada, cresce e dá origem a mata mais alta, mais grossa e mais rica em biodiversidade, dita capoeirão. Isto ocorre mediante recepção de elementos silvestres mais exigentes de umidade e sombra. O capoeirão é comum em antigas áreas de cultivo que não sendo mais desmatadas ultrapassam 5 metros.

O manejo feito pelas famílias, com base no etnoconhecimento, contribui para a conservação da vegetação. Os camponeses sabem exatamente qual a parte da planta que podem retirar a casca (foto 10), como devem perfurar a árvore para a extração da seiva e quais e quando as folhas e raízes estão apropriadas para o preparo de remédios, banhos entre outros. 
Foto 10 - Como fazer a retirada da casca para o preparo de um remédio.

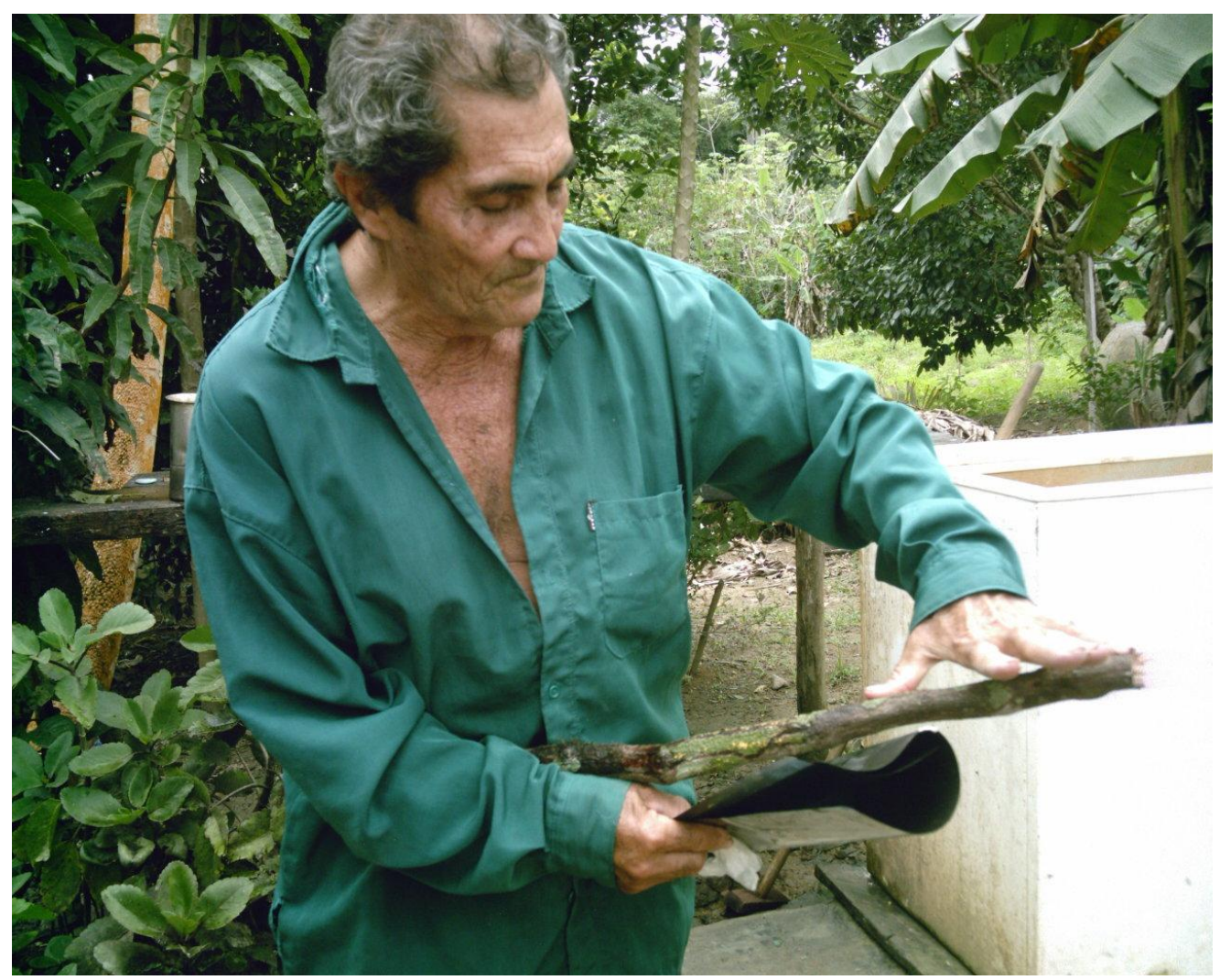

Fonte: Trabalho de campo, 2010-2012.

Nesta imagem o Sr. Raimundo nos mostra como deve ser retirada a casca da saracura, cipó encontrado na mata nativa, em seguida apresenta exames médicos confirmando estar curado de gastrite. Ao fundo da foto verifica-se a presença de árvores frutíferas como a mangueira e bananeira. Logo atrás há um jirau e logo abaixo, próximo ao caule do mamoeiro, tem outra planta medicinal chamada de corama (Bryophyllum pinnatum) (LORENZI, 2008).

O problema de saúde foi tratado com a casca da saracura deixada de molho (foto 11) e tal líquido deveria ser ingerido ao longo do dia, sendo substituído pelo ato de tomar água. O sabor amargo é atenuado pela refrigeração, mas como a eletrificação rural não é realidade em todos os sítios, as crianças apresentam maior resistência em ingerir esse remédio em temperatura natural. 
Foto 11 - Casca de molho da saracura

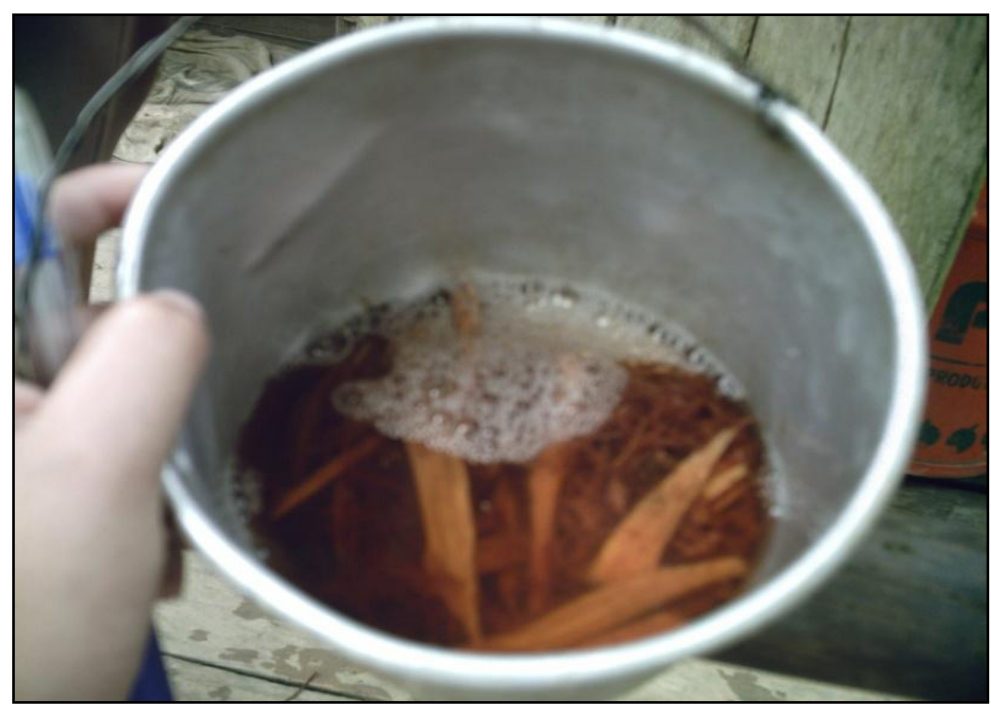

Fonte: Trabalho de campo, 2011.

Pra tirar a casca que presta tem que medir 1 palmo depois da noda [mancha] se num fô num presta. Se pegar a casca e deixar de molho na água fica um remédio pra gastrite, pode deixar na geladeira 'se tiver luz' que quando fica gelado dá pra beber melhor. Já a raspa dela de molho é boa pra falta de ar"."Pra quem tá com inframação de todo tipo toma o chá da casca da saracura.

Extrair corretamente a parte da planta garante a eficácia do remédio. Por isso não basta saber que a planta é medicinal, mas essa informação é transferência de saberes, conhecimentos herdados em grande parte de antepassados indígenas, conforme já apontado. Por essa razão, os estudos de Posey (1997, p.6) sobre os Kayapó, fornecem elementos para a compreensão da etnobiologia,

Os povos indígenas, mais que quaisquer outros, possuem informações acuradas sobre a diversidade biológica e as potencialidades dela resultantes para a captação de recursos naturais. Por coleta entende-se a obtenção de plantas silvestres, animais e produtos animais, bem como diversos elementos inertes adequados à alimentação, ao uso como matérias-primas manufatureiras ou remédios. [...] As plantas coletadas são utilizadas para a confecção de cordame, cobertura das casas, óleos, ceras, combustível, unguentos, ferramentas, ornamentos, perfumes, lenha pigmentos, tinturas, gomas, resinas e fibras, entre muitos outros usos [...].

As influências do conhecimento indígena são notórias. Em se tratando das plantas medicinais, os remédios provenientes de diferentes partes de uma mesma planta servem para diversas enfermidades. Os camponeses dominam as técnicas de 
se trabalhar com cipó e palha. Com o cipó pode-se fazer vassouras (foto 12), por exemplo, e a palha se faz cobertura de casas e hortas (foto 13).

Foto 12 - Vassoura de cipó, ideal para varrer o quintal.

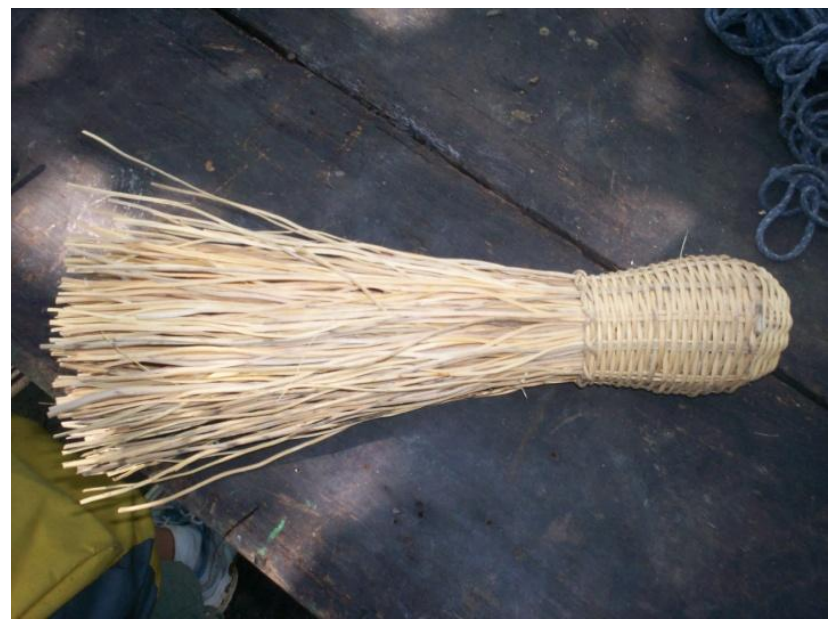

Foto 13 - Cobertura de palha.

Fonte: Trabalho de campo, 2010-2013.

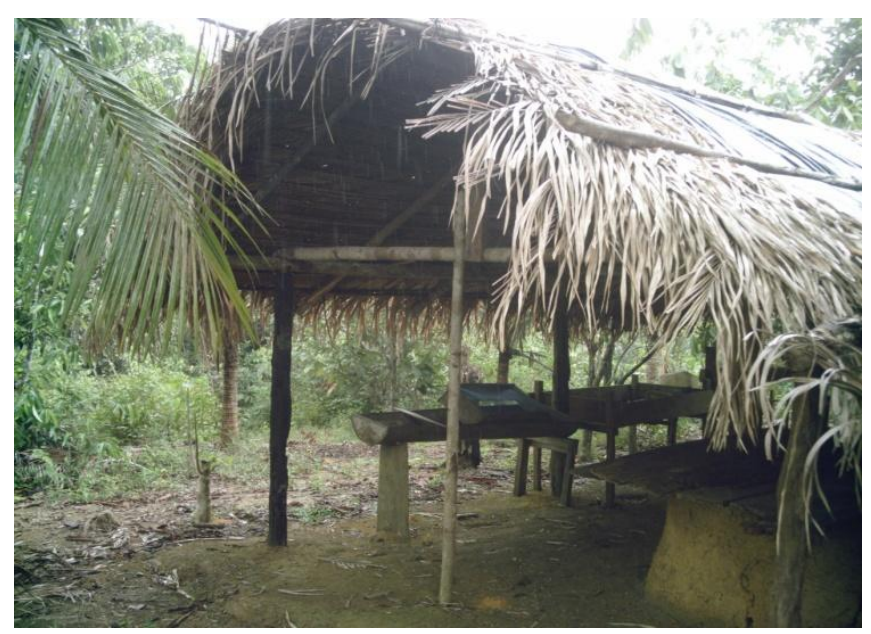

Terminadas as fases de entrevistas foram mencionadas 132 espécies de plantas medicinais ou com alguma serventia para o funcionamento do sítio. Quando há referência à determinada espécie para o preparo de um remédio, esta não se restringe apenas às doenças que afetam o corpo, mas também o espírito, como o quebrante ${ }^{11}$ e mau olhado (quadro 3).

A partir das informações colhidas em depoimentos sobre os remédios produzidos com base nas plantas foi possível verificar que as espécies proveem de diversos ambientes: a mata nativa, capoeira, capoeirinha e capoeirão.

As áreas próximas às casas, os quintais ou terreiros e varandas oferecem a possibilidade de verificação constante da adaptação das espécies trazidas de outros ambientes. Assim, plantas consideradas difíceis de encontrar precisam de cuidados constantes para sobreviver.

\footnotetext{
${ }^{11} \mathrm{O}$ quebrante é comum em crianças recém-nascidas. Quando alguém de má índole chega perto de um bebê pode ocorrer febre e diarreia e uma rezadeira faz um "banho" com plantas aromáticas (manjericão, erva-cidreira, malvarisco, mucuracaá) junto com rezas e puxações (massagens). Dependendo da intensidade do quebrante é preciso várias visitas à rezadeira. Os conhecimentos das rezadeiras são repassadas de mãe para filha.
} 
Quadro 3 - Plantas da Comunidade Pau Rosa

\begin{tabular}{|c|c|c|c|c|c|c|}
\hline & Planta & Citação & $\begin{array}{l}\text { Parte da } \\
\text { planta }\end{array}$ & Como faz & Serve para & Outras informações \\
\hline 1 & Abacateiro & $2 \%$ & Folha & Chá & Organismo fraco & \\
\hline 2 & Abacaxi & $2 \%$ & $\begin{array}{l}\text { Casca da } \\
\text { fruta }\end{array}$ & Suco & Bexiga inflamada & \\
\hline 3 & Abil selvagem & $5 \%$ & Casca & Chá & Gastrite & \\
\hline 4 & Abôta & $2 \%$ & Casca & Chá & Inflamação feminina & \\
\hline 5 & Açaí & $7 \%$ & Raiz & Chá & Ameba & \\
\hline 6 & Acerola & $2 \%$ & Fruta & Suco & Gripe & \\
\hline 7 & Alecrim & $2 \%$ & Folha & Chá & Lavar a cabeça & \\
\hline \multirow{2}{*}{8} & \multirow{2}{*}{ Alfavaca } & $2 \%$ & Folha & Chá & Dor de cabeça & $\begin{array}{l}\text { Ferve e deixa no sereno, na manhã } \\
\text { seguinte bebe. }\end{array}$ \\
\hline & & $9 \%$ & Semente & Natural & Limpa os olhos & $\begin{array}{l}\text { Retira-se as sementes e coloca direto } \\
\text { nos olhos }\end{array}$ \\
\hline 9 & Amapazeiro & $5 \%$ & Seiva & $\begin{array}{l}\text { Bate no } \\
\text { liquidificador }\end{array}$ & Diabete & $\begin{array}{l}\text { Tem que tirar três espumas, porque fica } \\
\text { muito forte. }\end{array}$ \\
\hline 10 & Amor agarradinho & $2 \%$ & & & Alimento das abelhas & \\
\hline 11 & Amor crescido & $5 \%$ & Folha & Chá & Inflamação & \\
\hline 12 & Amora & $5 \%$ & Folha & Chá & Repor hormônios & \\
\hline 13 & Andiroba & $2 \%$ & Óleo & Natural & Reumatismo & \\
\hline \multirow[t]{2}{*}{14} & \multirow[t]{2}{*}{ Araticum } & \multirow[t]{2}{*}{$2 \%$} & Folha & Chá & Dor de cabeça & $\begin{array}{l}\text { Ferve } 8 \text { folhas em } 1 \text { litro de água até ficar } \\
\text { laranjada. Põe no sereno e na manhã } \\
\text { seguinte lava a cabeça. }\end{array}$ \\
\hline & & & Fruto & Creme & & \\
\hline 15 & Arruda & $9 \%$ & Folha & Põe no álcool & Gripe, resfriado. & $\begin{array}{l}\text { Põe a folha no álcool com sementes de } \\
\text { jucá e fica cheirando o tempo todo. }\end{array}$ \\
\hline 16 & Artemísia & $2 \%$ & & & Alimento das abelhas & \\
\hline \multirow{2}{*}{17} & \multirow{2}{*}{ Azeitoneira } & \multirow{2}{*}{$7 \%$} & Folha & \multirow{2}{*}{ Chá } & \multirow{2}{*}{ Colesterol } & \\
\hline & & & Casca & & & \\
\hline 18 & Babosa & $7 \%$ & Folha & Chá & Estômago & \\
\hline 19 & Bananeira & $2 \%$ & Fruto & Natural & Colesterol & \\
\hline 20 & Bolda & $2 \%$ & Talo & Chá & Anemia & \\
\hline \multirow[t]{2}{*}{21} & \multirow[t]{2}{*}{ Boldo da folha pequena } & \multirow[t]{2}{*}{$7 \%$} & \multirow[t]{2}{*}{ Folha } & $\begin{array}{l}\text { Põe de molho } \\
\text { na água }\end{array}$ & Fígado & \multirow[t]{2}{*}{ Mastiga a folha } \\
\hline & & & & Natural & Estômago & \\
\hline 22 & Boldo liso, figa tilo & $16 \%$ & Galho & $\begin{array}{l}\text { Põe de molho } \\
\text { na água }\end{array}$ & Dor nos olhos & \\
\hline 23 & Café & $2 \%$ & Folha & Chá & Pressão alta & \\
\hline 24 & Cajá do mato & $2 \%$ & Fruta & Suco & Gripe & \\
\hline 25 & Cajueiro & $2 \%$ & Casca & Chá & $\begin{array}{l}\text { Lavar ferimentos e } \\
\text { inflamação }\end{array}$ & Junto com a casca da azeitona \\
\hline 26 & Cana & $2 \%$ & Folha & Chá & Emagrecer & \\
\hline 27 & Canapum & $2 \%$ & Folha & & $\begin{array}{l}\text { "trabalho de } \\
\text { macumba" }\end{array}$ & \\
\hline 28 & Capeba/capeva & $5 \%$ & Folha & Chá & Antiinflamatório & É alimento para os porcos \\
\hline 29 & Capim & $2 \%$ & Raiz & \begin{tabular}{|l|}
$\begin{array}{l}\text { Bate no } \\
\text { liquidificador } \\
\text { com água }\end{array}$ \\
\end{tabular} & Hemorroida & \\
\hline 30 & Capim furão & $2 \%$ & Raiz & Chá & $\begin{array}{l}\text { Inflamação, infecção } \\
\text { urinária, diabete }\end{array}$ & $\begin{array}{l}\text { Chama-se assim em função de furar as } \\
\text { plantas ao redor. }\end{array}$ \\
\hline 31 & Capim santo & $14 \%$ & Folha & Chá & $\begin{array}{l}\text { Calmante, dor de } \\
\text { estômago. }\end{array}$ & \\
\hline 32 & Carambola & $2 \%$ & Fruta & Suco & Gripe & \\
\hline
\end{tabular}




\begin{tabular}{|c|c|c|c|c|c|c|}
\hline 33 & Carapanaúba & $14 \%$ & Casca & Chá & $\begin{array}{l}\text { Febre tifoide, } \\
\text { hepatite, fígado, } \\
\text { malária }\end{array}$ & \\
\hline 34 & Carmelitana & $5 \%$ & Folha & Chá & Dor de estômago & \\
\hline 35 & Castanha da índia & $2 \%$ & Fruto & Natural & Espanta cobras & $\begin{array}{l}3^{\circ} \text { maior problema de saúde no } \\
\text { assentamento. Picada de animais } \\
\text { peçonhentos }\end{array}$ \\
\hline 36 & Cibalena & $2 \%$ & Folha & Chá & Dor de cabeça & \\
\hline 37 & Cipó alho & $7 \%$ & Folha & Chá & $\begin{array}{l}\text { Sinusite, gripe, dor de } \\
\text { estômago, dor de } \\
\text { cabeça. }\end{array}$ & \\
\hline 38 & Cipó bôta & $2 \%$ & Casca & Chá & Malária, fígado & \\
\hline 39 & Cipó escada de jabuti & $5 \%$ & Casca & $\begin{array}{l}\text { Põe de molho } \\
\text { na água }\end{array}$ & Inflamação & \\
\hline 40 & Cipó tuíra & $2 \%$ & Casca & Chá & Anemia & \\
\hline \multirow[b]{2}{*}{41} & \multirow[b]{2}{*}{ Citronela } & \multirow[b]{2}{*}{$2 \%$} & Folha & \multirow{2}{*}{$\begin{array}{l}\text { Macera tudo e } \\
\text { deixa três dias } \\
\text { de molho e } \\
\text { molha as } \\
\text { plantas. } \\
\end{array}$} & \multirow[b]{2}{*}{$\begin{array}{l}\text { Detergente } \\
\text { inseticida }\end{array}$} & \multirow[b]{2}{*}{$\begin{array}{l}\text { Necessário uma "panela" especial para } \\
\text { capturar o vapor proveniente da fervura } \\
\text { da planta. }\end{array}$} \\
\hline & & & Raiz & & & \\
\hline 42 & Comida de abelha & $2 \%$ & & & Alimento das abelhas & $\begin{array}{l}\text { Não sabe o nome da planta, então é } \\
\text { chamado pela função que ela exerce na } \\
\text { produção de mel. }\end{array}$ \\
\hline 43 & Copaíba & $7 \%$ & Casca & $\begin{array}{l}\text { Põe de molho } \\
\text { na água }\end{array}$ & Infecção & \\
\hline 44 & Corama, coirama & $30 \%$ & Folha & Chá & Inflamação & \\
\hline 45 & Crajiru & $12 \%$ & Folha & Chá & Inflamação feminina & \\
\hline 46 & Cravo de defunto & $2 \%$ & Flor & Põe no álcool & Sinusite & \\
\hline \multirow{2}{*}{47} & \multirow{2}{*}{ Cubiu } & \multirow{2}{*}{$12 \%$} & \multirow{2}{*}{ Fruto } & Natural & Diabete, colesterol & \\
\hline & & & & Faz o suco & Pressão alta & \\
\hline \multirow[t]{2}{*}{48} & \multirow[t]{2}{*}{ Cumaru } & \multirow[t]{2}{*}{$5 \%$} & Semente & $\begin{array}{l}\text { Soca a } \\
\text { semente e } \\
\text { deixa de molho } \\
\text { na água. } \\
\end{array}$ & Dor no ouvido & \\
\hline & & & Casca & $\begin{array}{l}\text { Põe de molho } \\
\text { na água }\end{array}$ & $\begin{array}{l}\text { Asma, pneumonia, } \\
\text { reumatismo }\end{array}$ & \\
\hline 49 & Elixir paregórico & $9 \%$ & Folha & Chá & Prisão de ventre & \\
\hline 50 & Erva cidreira, melissa & $2 \%$ & Folha & Chá & $\begin{array}{l}\text { Dor de cabeça, } \\
\text { calmante }\end{array}$ & \\
\hline 51 & Erva comida de jabuti & $2 \%$ & Folha & Chá & Pressão alta & \\
\hline 52 & Erva de passarinho & $2 \%$ & Casca & Chá & Infecção & \\
\hline 53 & Eucalipto & $2 \%$ & Folha & Chá & Febre & \\
\hline 54 & Flor roxa & $2 \%$ & Flor & Chá & $\begin{array}{l}\text { Doenças cardíacas, } \\
\text { gripe }\end{array}$ & \\
\hline 55 & Gergelim & $2 \%$ & Semente & Natural & AVC & $\begin{array}{l}\text { Esmaga a semente e mistura com } \\
\text { andiroba ou copaíba e faz massagem na } \\
\text { área afetada. }\end{array}$ \\
\hline 56 & Goiabeira & $2 \%$ & Folha & Chá & Diarreia & $\begin{array}{l}\text { A guia é a ponta do galho com folha } \\
\text { nova. }\end{array}$ \\
\hline 57 & Gravioleiro & $2 \%$ & Folha & Chá & Rins, cisto & \\
\hline 58 & Hortelã grande, pimenta & $12 \%$ & Folha & $\begin{array}{l}\text { Faz o melado } \\
\text { ou lambedor }\end{array}$ & Gripe & $\begin{array}{l}\text { Ferver a folha com pouco água, quando } \\
\text { engrossar adicionar mel de abelha. }\end{array}$ \\
\hline \multirow{2}{*}{59} & \multirow{2}{*}{ Hortelãnzinho } & \multirow{2}{*}{$9 \%$} & \multirow{2}{*}{ Folha } & \multirow{2}{*}{ Chá } & Cólica de criança & \\
\hline & & & & & Diarreia & \\
\hline \multirow{2}{*}{60} & \multirow{2}{*}{ Imbaúba branca } & \multirow{2}{*}{$2 \%$} & Vagem & \multirow{2}{*}{$\begin{array}{l}\text { Tira a raspa e } \\
\text { mistura com a }\end{array}$} & \multirow{2}{*}{ Reumatismo } & \multirow{2}{*}{$\begin{array}{l}\text { Passar na parte doente na hora de } \\
\text { dormir. }\end{array}$} \\
\hline & & & Casca & & & \\
\hline
\end{tabular}




\begin{tabular}{|c|c|c|c|c|c|c|}
\hline & & & Seiva & seiva & & \\
\hline 61 & Jambú & $7 \%$ & Folha & Chá & Fígado & \\
\hline 62 & Japana breca & $2 \%$ & Casca & Chá & Inflamação & \\
\hline \multirow{3}{*}{63} & \multirow{3}{*}{ Jatobá } & \multirow{3}{*}{$14 \%$} & \multirow{3}{*}{ Casca } & Chá & $A V C$ & \\
\hline & & & & $\begin{array}{l}\text { Cozinha por } 2 \\
\text { horas }\end{array}$ & Falta de ar & Mistura com o óleo de copaíba. \\
\hline & & & & Ferve na água & Bronquite & Ferver até escurecer e põe açúcar. \\
\hline \multirow{2}{*}{64} & \multirow{2}{*}{ Jenipapo } & \multirow{2}{*}{$7 \%$} & Casca & \multirow{2}{*}{ Faz o suco } & Quebradura & \\
\hline & & & Fruto & & Anemia & \\
\hline 65 & Jucá & $12 \%$ & Casca & Ferve na água & Gripe e inflamação & \\
\hline \multirow{3}{*}{66} & \multirow{3}{*}{ Jurubeba da fruta grande } & \multirow{3}{*}{$2 \%$} & Folha & \multirow{3}{*}{$\begin{array}{l}\text { Bate tudo no } \\
\text { liquidificador } \\
\text { com água }\end{array}$} & \multirow{3}{*}{ Úlcera no estômago } & \\
\hline & & & Fruto & & & \\
\hline & & & Galho & & & \\
\hline 67 & Jurubeba da fruta pequena & $2 \%$ & Folha & Chá & Diabete & \\
\hline 68 & Laranjeira & $7 \%$ & Folha & Chá & Gripe & \\
\hline 69 & Lima & $2 \%$ & Folha & Chá & Gripe, tosse & Junto com alho \\
\hline 70 & Limão & $19 \%$ & Casca & Chá & Gripe & \\
\hline 71 & Limão galego & $2 \%$ & Fruto & Suco & Gripe & é maior que o limão comum. \\
\hline 72 & Limão tangerina & $2 \%$ & Fruto & Suco & Gripe & \\
\hline 73 & Malvarisco & $7 \%$ & Folha & Chá & Catarro no peito & Mistura com jambú e casca do jatobá. \\
\hline \multirow{2}{*}{74} & \multirow{2}{*}{ Mangaratáia, gengibre } & \multirow{2}{*}{$9 \%$} & Raiz & \multirow{2}{*}{ Chá } & \multirow{2}{*}{$\begin{array}{l}\text { Garganta, tosse e } \\
\text { gripe }\end{array}$} & \\
\hline & & & Folha & & & \\
\hline 75 & $\begin{array}{l}\text { Mangaratáia amarela, } \\
\text { açafrão }\end{array}$ & $2 \%$ & Fruto & Macera & Corante & \\
\hline 76 & Manjericão & $7 \%$ & Planta toda & Fazer banho & Amansar criança & \\
\hline 77 & Mastruz, mentruz & $7 \%$ & Folha & $\begin{array}{l}\text { Bate no } \\
\text { liquidificador } \\
\text { com leite }\end{array}$ & Gripe, tuberculose & \\
\hline 78 & Mata calado & $2 \%$ & Planta toda & & Veneno & \\
\hline 79 & Monjongome/carirú & $2 \%$ & Folha & $\begin{array}{ll}\begin{array}{l}\text { Coloca } \\
\text { feijão }\end{array} & \text { no } \\
\end{array}$ & Tempero & \\
\hline \multirow{3}{*}{80} & \multirow{3}{*}{ Mucura caá } & \multirow{3}{*}{$2 \%$} & \multirow{3}{*}{ Folha } & Natural & $\begin{array}{l}\text { "trabalho de } \\
\text { macumba" }\end{array}$ & \\
\hline & & & & \multirow{2}{*}{ Chá } & Tosse & Gargarejo \\
\hline & & & & & Dor de cabeça & Banho \\
\hline 81 & Muruci amarelo & $2 \%$ & Casca & Chá & Tuberculose & $\begin{array}{l}\text { Ferver junto com a casca do muruci } \\
\text { branco. }\end{array}$ \\
\hline 82 & Muruci branco & $2 \%$ & Casca & Chá & Tuberculose & $\begin{array}{l}\text { Ferver junto com a casca do muruci } \\
\text { amarelo. }\end{array}$ \\
\hline 83 & Muruci nativo & $2 \%$ & Casca & Chá & Tuberculose & \\
\hline \multirow{2}{*}{84} & \multirow{2}{*}{ Mururé } & \multirow{2}{*}{$2 \%$} & Casca & Chá & Pneumonia & \\
\hline & & & Óleo & Natural & Reumatismo & \\
\hline 85 & Mutuquinha & $2 \%$ & Folha & Chá & Hemorragia & \\
\hline 86 & None & $5 \%$ & Fruta & Suco & $\begin{array}{l}\text { Pra todo tipo de } \\
\text { inflamação e câncer. }\end{array}$ & \\
\hline 87 & Oriza & $5 \%$ & Folha & Chá & Labirintite e coração & \\
\hline 88 & Pata de vaca & $5 \%$ & Folha & Chá & Diabete & \\
\hline 89 & Patchuli, cheiro do Pará & $2 \%$ & Raiz & Põe no álcool & Dor de cabeça & Tem que ficar cheirando todo o tempo. \\
\hline
\end{tabular}




\begin{tabular}{|c|c|c|c|c|c|c|}
\hline 90 & Pau da angola & $2 \%$ & Casca & Chá & Infecção & \\
\hline 91 & Pau d'arco & $2 \%$ & Casca & $\begin{array}{l}\text { Põe de molho } \\
\text { na água }\end{array}$ & Dor de cabeça & Não pode ferver senão perde o efeito. \\
\hline 92 & Pau de adão & $2 \%$ & Caule, seiva & $\begin{array}{l}\text { Passa em cima } \\
\text { do ferimento }\end{array}$ & Verruga e micoses. & \\
\hline 93 & Pau milagroso & $2 \%$ & Raspa & $\begin{array}{l}\text { Põe de molho } \\
\text { na água }\end{array}$ & Falta de ar & \\
\hline 94 & Pau rosa & $2 \%$ & Óleo & & Perfume & $\begin{array}{l}\text { Não existem mais espécies dessa } \\
\text { planta no ramal Pau Rosa. }\end{array}$ \\
\hline \multirow[b]{2}{*}{95} & \multirow[b]{2}{*}{ Pião branco } & \multirow[b]{2}{*}{$12 \%$} & Folha & Chá & Leshmaniose, infarto & \\
\hline & & & Semente & Torra no fogo & Vermífugo & $\begin{array}{l}\text { Torra a fruta quebra e torra de novo, rala } \\
\text { e põe açúcar e queima, põe } 1 \text { copo de } \\
\text { goma, molda como pílula e toma } 1 \text { por } \\
\text { dia durante } 8 \text { dias. }\end{array}$ \\
\hline \multirow[t]{2}{*}{96} & \multirow[t]{2}{*}{ Pião roxo } & \multirow[t]{2}{*}{$5 \%$} & \multirow[t]{2}{*}{ Folha } & Chá & $\begin{array}{l}\text { Câncer no colo do } \\
\text { útero }\end{array}$ & $\begin{array}{l}\text { Mistura com erva de passarinho, mais } \\
\text { só serve se for do cajueiro. E Lava a } \\
\text { vagina. }\end{array}$ \\
\hline & & & & Natural & Rezar em criança & Proteger contra o quebranto. \\
\hline 97 & Pimenta de macaco & $2 \%$ & Semente & Chá & Inseticida & \\
\hline 98 & Pobre velho & $5 \%$ & Folha & Chá & Rins & \\
\hline 99 & Preciosa & $2 \%$ & Casca & Chá & Prisão de ventre & \\
\hline 100 & Puruí & $2 \%$ & Fruto & Suco & $\begin{array}{l}\text { Dor no estômago, dor } \\
\text { de cabeça. }\end{array}$ & \\
\hline 101 & Quebra pedra & $5 \%$ & Raiz & Chá & Rins & $\begin{array}{l}\text { As raízes das plantas quebra pedra e } \\
\text { pobre velho podem ser utilizadas juntas } \\
\text { no preparo do chá. }\end{array}$ \\
\hline 102 & Quina quina & $7 \%$ & Casca & Chá & Malária & \\
\hline 103 & Quina quina amarelo & $2 \%$ & Casca & $\begin{array}{l}\text { Põe de molho } \\
\text { na água }\end{array}$ & $\begin{array}{l}\text { Febre, malária, } \\
\text { fígado, calmante, dor } \\
\text { de estômago. }\end{array}$ & \\
\hline 104 & Rinchão & $5 \%$ & Folha & \begin{tabular}{|l} 
Tritura e \\
mistura na \\
água \\
\end{tabular} & Pedra nos rins & $\begin{array}{l}\text { Pode colocar a folha socada diretamente } \\
\text { no lugar da picada de cobra. }\end{array}$ \\
\hline 105 & Sacaca & $2 \%$ & Folha & Chá & Malária, fígado & \\
\hline 106 & Saião & $2 \%$ & Folha & $\begin{array}{l}\text { Esquenta na } \\
\text { brasa }\end{array}$ & Feridas & \\
\hline 107 & Samambaia & $2 \%$ & Folha & Chá & Queda de cabelo & \\
\hline 108 & Saracura & $7 \%$ & Raspa & $\begin{array}{l}\text { Coloca de } \\
\text { molho }\end{array}$ & Antibiótico & \\
\hline \multirow{3}{*}{109} & \multirow{3}{*}{ Saracura mirá } & \multirow{3}{*}{$7 \%$} & Raspa & $\begin{array}{l}\text { Põe de molho } \\
\text { na água }\end{array}$ & Falta de ar & \\
\hline & & & \multirow[b]{2}{*}{ Casca } & Chá & Inflamação & \\
\hline & & & & $\begin{array}{l}\text { Põe de molho } \\
\text { na água }\end{array}$ & Gastrite & \\
\hline 110 & Saratudo & $7 \%$ & Folha & Chá & $\begin{array}{l}\text { Serve como } \\
\text { antibiótico }\end{array}$ & \\
\hline 111 & Sova de marajó & & Folha & Chá & Dor no estômago & \\
\hline 112 & Stevea & $2 \%$ & Folha & Ferver & $\begin{array}{l}\text { Substitui o açúcar ou } \\
\text { adoçante para o } \\
\text { diabético. }\end{array}$ & $\begin{array}{l}\text { Para o preparo de café, é preciso ferver } \\
5 \text { folhas de Stevea. }\end{array}$ \\
\hline 113 & Sucuba & $2 \%$ & Casca & Chá & Câncer & \\
\hline 114 & Tamarindo & $2 \%$ & Folha & Chá & Doenças cardíacas & \\
\hline 115 & Taperebá & $5 \%$ & Semente & Chá & Próstata & $\begin{array}{l}\text { São } 3 \text { sementes misturadas com três } \\
\text { sementes de limão. }\end{array}$ \\
\hline 116 & Teca & $2 \%$ & Casca & & $\begin{array}{l}\text { "trabalho de } \\
\text { macumba" }\end{array}$ & \\
\hline 117 & Tiririca & $2 \%$ & Raiz & Chá & Infecções urinárias & \\
\hline 118 & Trefrósia & $2 \%$ & & & $\begin{array}{l}\text { Fixa nitrogênio no } \\
\text { solo }\end{array}$ & \\
\hline
\end{tabular}




\begin{tabular}{|c|c|c|c|c|c|c|}
\hline 119 & Trevo roxo & $2 \%$ & Folha & Folha triturada & Dor no ouvido & Deve ser misturada com leite humano. \\
\hline \multirow{2}{*}{120} & \multirow{2}{*}{ Uxí amarelo } & \multirow{2}{*}{$7 \%$} & \multirow{2}{*}{ Casca } & Ferve na água & Derrame & $\begin{array}{l}\text { Misturar as casca do jatobá, xixuá e } \\
\text { ferver. }\end{array}$ \\
\hline & & & & $\begin{array}{l}\text { Põe de molho } \\
\text { na água }\end{array}$ & Fígado & \\
\hline 121 & Uxí branco & $2 \%$ & Casca & $\begin{array}{l}\text { Põe de molho } \\
\text { na água }\end{array}$ & Fígado & \\
\hline 122 & Uxí Coroa & $2 \%$ & Casca & Ferve na água & Tuberculose & $\begin{array}{l}\text { Indicado para o tratamento de } \\
\text { tuberculose somente no início. }\end{array}$ \\
\hline 123 & Uxí liso & $2 \%$ & Casca & Ferve na água & Inflamação & \\
\hline 124 & Unha de gato & $2 \%$ & Casca & Ferve na água & Tuberculose & \\
\hline \multirow{2}{*}{125} & \multirow{2}{*}{ Urucum } & \multirow{2}{*}{$2 \%$} & Folha & \multirow{2}{*}{ Chá } & \multirow{2}{*}{ Pressão alta, anemia } & \multirow{2}{*}{ Misturar com a raiz do açaí. } \\
\hline & & & Raiz & & & \\
\hline 126 & Vassourinha & $7 \%$ & Folha & Põe no álcool & Hematoma & \\
\hline \multirow{2}{*}{127} & \multirow{2}{*}{ Vassourinha de botão } & \multirow{2}{*}{$7 \%$} & Folha & \multirow{2}{*}{ Chá } & \multirow{2}{*}{ Hemorroida } & \\
\hline & & & Botão & & & \\
\hline 128 & Vick & $2 \%$ & Folha & Chá & Gripe & \\
\hline 129 & Vinagreira & $5 \%$ & Folha & Chá & Emagrecer & é diurético também. \\
\hline 130 & Vinde cá & $2 \%$ & Folha & Ferve na água & Dor de cabeça & \\
\hline 131 & Xixarró & $2 \%$ & Casca & Chá & Inflamação & \\
\hline \multirow[b]{2}{*}{132} & \multirow[b]{2}{*}{ Xixuá } & \multirow[b]{2}{*}{$7 \%$} & \multirow[b]{2}{*}{ Casca } & Ferve na água & Derrame & \\
\hline & & & & $\begin{array}{l}\text { Põe de molho } \\
\text { na água }\end{array}$ & Fígado & \\
\hline
\end{tabular}

Fonte: Trabalhos de campo, 2010-2012.

As trocas de espécies e receitas são frequentes entre as mulheres, comadres, enquanto aos homens fica a função de fazer as trilhas na mata e trazer a matériaprima, no entanto, as mulheres dominam as técnicas de preparo.

As informações contidas no quadro 3 são provenientes dos trabalhos de campo nos sítios. Os camponeses nos mostravam as plantas cultivadas nos quintais, a serventia e o modo de preparo dos remédios.

Há uma cobrança sobre as mulheres para que conheçam as plantas e os remédios. As mães precisam conhecer as doenças tratadas em casa, como também devem ser capazes de preparar chás, xaropes, sucos para a recuperação de um enfermo.

A maior ocorrência de plantas para a resolução de doenças no sistema respiratório e digestivo com 33 e 27 citações respectivamente. Em seguida, com 15 citações as doenças infecciosas e parasitárias, com 8 citações as doenças do sistema genito urinário, com 6 citações cada estão as doenças do sistema osteomuscular e tecido conjuntivo e sistema cardiovascular. 
Esta diversidade de espécies e usos revela a heterogeneidade do etnoconhecimento camponês. As plantas mais citadas refletem as doenças consideradas comuns, portanto, facilmente curáveis. Dentre estas se destacam as inflamações, dores no estômago, problemas no fígado causado por hepatite ou malária. Nas citações das plantas, é possível identificar as quantidades de ocorrências e relacionar a planta mais usada com as doenças (gráfico 3).

Gráfico 3 - Plantas medicinais mais citadas.

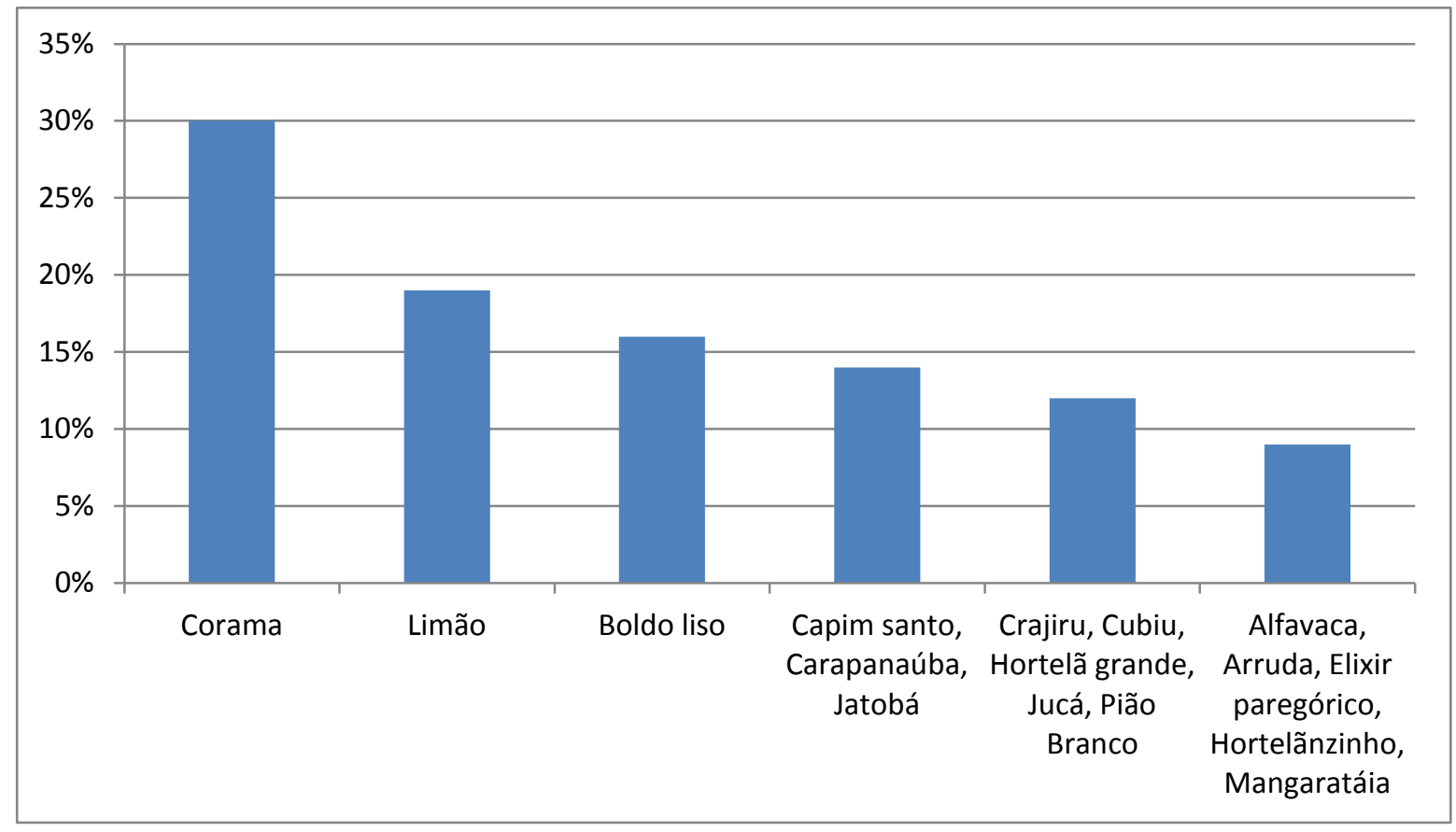

Fonte: Trabalhos de campo 2010-2012.

Em menor proporção de uso estão aquelas plantas utilizadas para o tratamento de doenças com maior complexidade. É o caso de AVC, asma, pneumonia, doenças cardíacas, úlcera, tuberculose, hemorragias, câncer, mordida de animais peçonhentos. Quando há algum sintoma de alguma das enfermidades descritas o caso é encaminhado para Manaus. É interessante notar que o uso de remédios caseiros é feito simultaneamente com o tratamento feito nos hospitais.

Esse é o uso da paisagem entendida como herança de processos fisiográficos e históricos conforme Ab'Sáber (2003:09). O conhecimento das plantas e a modificação do ambiente para o cultivo foram produzidos em localidades específicas e ao chegarem à Comunidade trouxeram plantas dos lugares em que 
moraram antes, assim, trazendo para a sua atual moradia elementos que faziam parte de seu cotidiano.

Em um dos casos a planta chamada de "pau milagroso" foi trazida de Nova Olinda do Norte (AM) para o tratamento e prevenção de pneumonia e cansaço, de acordo com um dos entrevistados:

Meu vô usava a raspa do pau milagroso, minha falecida mãe tamém e quando nós ou um conhecido tá no roçado e num guenta trabaiá, pra tudo fica fartando o ar, pode fazer e tomar com muita fé em Deus que fica bonzinho. Pega a raspa e tira o tanto de uma colher e bota de molho, bota na geladeira e toma no lugar da água (Sr. R.S).

As plantas mais utilizadas retratam a necessidade do uso de remédios para a resolução de problemas de saúde que os camponeses consideram como "duença besta” curáveis com chás, banhos e rezas. O médico é procurado em casos que fogem aos seus conhecimentos, como ataque cardíaco, câncer, febre que não passa.

Enquanto, em determinados casos aprendem a serventia e modos de preparo de certas espécies com os médicos. Assim como evitar alguns alimentos, como relatado em um caso,

eu já tava cum umas cinco vez que pegava a lesh (leshimaniose) e tratava e num dava jeito, ponhava o sumo do hortelã grosso, [e como tira o sumo?] acende um fogo e bota a foia numa cuié e dêxa longe do fogo é só pra pegá o calô, aí vai saí uma água, aí já e depois cobre cum a foia, aí o dotô falô que num tinha comprovação científica mas que eu dexasse de comê carne de caça por uns tempo, aí eu sarei de verdade (Sr. F. J.).

apareceu umas inframação que saía de mim uma coisa mei branca igual requeijão, sabe?, dô no pé da barriga, aí a médica das muié passô uns banho e fazê o chá [lembra qual planta?] não me alembro, mais sei que tem aqui no sítio que a minha mãe que fez, eu fui no hospitar só purque tava na cidade, que a mãe e a vó são bem entendida nessas coisa. (Sra. M.C)

As plantas, na maioria das vezes, resolvem os problemas imediatos. Entretanto, os camponeses lutam para que tenha um posto de saúde bem equipado e com um médico a disposição, conforme anunciado pelo INCRA no plano de desenvolvimento do assentamento. 
Um dos entrevistados sofreu um AVC (acidente vascular cerebral) e ficou hospitalizado por quatro anos, segundo ele, sem melhora significativa, ou seja, sem condições físicas para o trabalho, visto que o cultivo depende exclusivamente da sua força de trabalho - pois vive com a esposa e mais quatro netos e os filhos moram na cidade - ficou impaciente com a situação e apreensivo com a possibilidade de perder o lote, resolveu deixar o hospital e preferiu se tratar com remédios à base de plantas preparadas pela esposa. O tratamento era intensivo até que recuperou os movimentos.

Os médico que nós fomos falaram pra mulhé que eu não escapava, já era quatro vezes que eu pegava derrame. Aí eu fiquei quatro anos no hospital, e nãom melhorava, aí eu falei pra mulhé pra gente voltá pro sítio. Aí ela se virava de tudo que era jeito, procurava remédio, pedia planta, tudo que ensinava pra ela, ela fazia. Quando eu saí do hospital eu não fazia assim com braço (movimentar no sentido horário). Eu só fazia assim (erguia o braço para frente com dificuldade até a altura do ombro). Hoje eu até já aguento bem a roça. (Sr. R. S.)

A Sra. R. S. a partir dos conhecimentos adquiridos com a mãe e pesquisas de remédios com as comadres passou a cultivar as plantas necessárias para a medicação do marido, não tem muito conhecimento sobre as plantas da mata, mas estava sempre em busca de informações que pudessem auxiliá-la no preparo de algum outro remédio.

Umas coisa eu aprendi com a mãe, já otras foi como vinha as doença pra ele. Aí quando ele caía duente eu ia procurá remédio. Ele já teve morróida aí me insinaru o chá da vassorinha de butão, essa vassorinha dá iguar praga; garanto que o povo num sabe que é remédio, outra coisa foi a pressão dele que é arta, aí eu tava na fila do posto pra marcá consurta pra ele quando eu ouvi duas muié falando de pressão arta, aí eu fiquei de butuca só ouvindo elas, aí uma insinô pra otra o chá da folha da zeitonera, dessa pretinha que dá in tudo que é canto. Quando cheguei em casa dei pra ele, e num é que deu certo? (Sra. R. S.)

É interessante notar este fato na fila do posto de saúde em Manaus, enquanto o marido estava hospitalizado, ela ouviu da senhora à sua frente uma receita para baixar a pressão arterial, que é o chá da folha da azeitoneira (Syzygium cumini Skells). Chegando a sua casa, preparou o chá e a partir daí passou a utilizar 
continuamente para controlar a pressão arterial do marido. Percebe-se, portanto, as pesquisas, mesmo que involuntárias são úteis para a cura de doenças.

Se comparada a mãe, a Sra. R. S. afirma não possuir tantos conhecimentos de plantas e remédios,

Sr. R. S.: A minha véia sabe fazê um monte de murundanga, é remédio, é reza, mais a véia mãe dela, vixe, ela era famosa lá no Nova Olinda. Ela era partêra, rezadêra, fazia garrafada, xarope pra gripe, de tudo a véia sabia era intendida. Mais aí, a véia tá do jeito que ocê tá vendo aí, fica andando dum lado pro outro e num fala mais coisa cum coisa, tá só esperando a hora de Deus chamá.

Sra. R. S.: É verdade, a mãe é bem intendida. Vinha gente de longe pra tratá cum ela, pegá pranta, remédio. Agora ela táqui cun nóis, tá caduca, caduca. Ela nun cobrava nada, que Deus deu o cunhecimento prá ajudá as pessoa, se cobrá já perde o dom, mais se a pessoa vê e querê dá arguma coisa ela aceitava que a gente era pobre memo, mais a gente ajudava gente de todo tipo memo. Pras minha nora eu falo, cês aprende a cuidá dos marido docês, aprende fazê um chá, prantá as coisa. É que elas são da cidade, mais pras minha minina quando elas toma uma idade de i pra cozinha já vô logo mostrando com que faz o chá, o café. Aí os meu minino casa e vem aqui pra pedi chá pra mim, vê se pode? Eles já rumaram casa e muié, elas que tem de tratá deles, num é memo?

O depoimento desta senhora expressa diversos elementos da cultura camponesa. O cuidado com os idosos e a relação estabelecida com as pessoas do lugar de onde vieram são expressos numa relação de reciprocidade na qual não é tolerável o pagamento de plantas e remédios, por uma questão moral. A obtenção de lucro ou ganhar a partir de um dom divino faz com que a pessoa "escolhida por Deus" perca os dons mágicos. A pobreza não era justificativa para a desonra de receber pagamento referente a um dom divino.

Outra questão é a referente à família. Os filhos já crescidos precisam que as esposas se tornem companheiras e possam, em um momento de infortúnio, amparar devidamente o marido. Estas, na condição de donas da casa, devem trabalhar para o bem estar da família. Tais atribuições, no entanto, vão além dos serviços domésticos. Cultivar plantas medicinais e saber identificar as enfermidades é importante para evitar o agravamento de problemas de saúde e assim não comprometer a mão de obra do sítio e consequentemente o sustento da família.

A energia elétrica advinda do "Projeto Luz para Todos" também contribuiu para o aprendizado de remédios a base de plantas por meio dos programas de 
televisão ${ }^{12}$. Os alimentos passaram a ser conservados na geladeira ou refrigeradores. As frutas que antes eram "desperdiçadas" e viravam adubo por falta de armazenamento adequado passaram a ser transformadas em doces e polpas.

Em relação às plantas medicinais há um caso em que a senhora C.S. adquiriu fitas cassete para estudar técnicas de plantio e diversidade de plantas, formas de cultivo e preparo; de modo que se tornou referência no assentamento em plantas medicinais cultivadas de fora da natureza do lugar, pois não coleta plantas da mata nativa, ela afirma não ter paciência para andar na mata, tal tarefa é delegada ao marido. Os usos das plantas e os modos de preparo são registrados em cadernos que contém ensinamentos da mãe, da avó e o que se aprende nos programas sobre agricultura e fitas cassete.

O que se aprende na televisão como, por exemplo, preparar um inseticida, demanda um equipamento específico que só é possível a compra em outros estados, e nesse caso, quando se tem a matéria-prima as técnicas podem ser substituídas. Por exemplo, a pimenta de macaco (Piper aducum L.) é utilizada como inseticida tal qual foi ensinado numa fita cassete. No entanto, para realizar o processo era necessária a compra de uma máquina que ferveria a semente e o vapor seria aprisionado num recipiente para borrifar na planta. Sem condições de comprar a máquina e precisando de um inseticida, a Sra. C. S. ferveu as sementes da pimenta de macaco, colocou um pano entre a tampa e a panela e ao fim da fervura amarrava o pano na planta e regava as plantas com a água restante e assegurou eficácia da receita.

Dois sítios na comunidade Pau Rosa são conhecidos como as "farmácias naturais" do assentamento. São os sítios do Sr. Raimundo "da cabeça branca", localizado ao lado da escola e o da Sra. Creuza, na vicinal Dantas. Todos os remédios já conhecidos e os apreendidos há pouco tempo são escritos em cadernos de forma a preservar as informações (foto 14).

\footnotetext{
${ }^{12}$ No canal local Amazon Sat, é veiculado aos domingos pela manhã o programa "plantas e ervas medicinais", e na rede globo foram citados programas como "globo rural, globo repórter, jornal hoje e fantástico" como importantes para se aprender mais receitas com plantas.
} 
Foto 4 - Registros das receitas dos remédios.

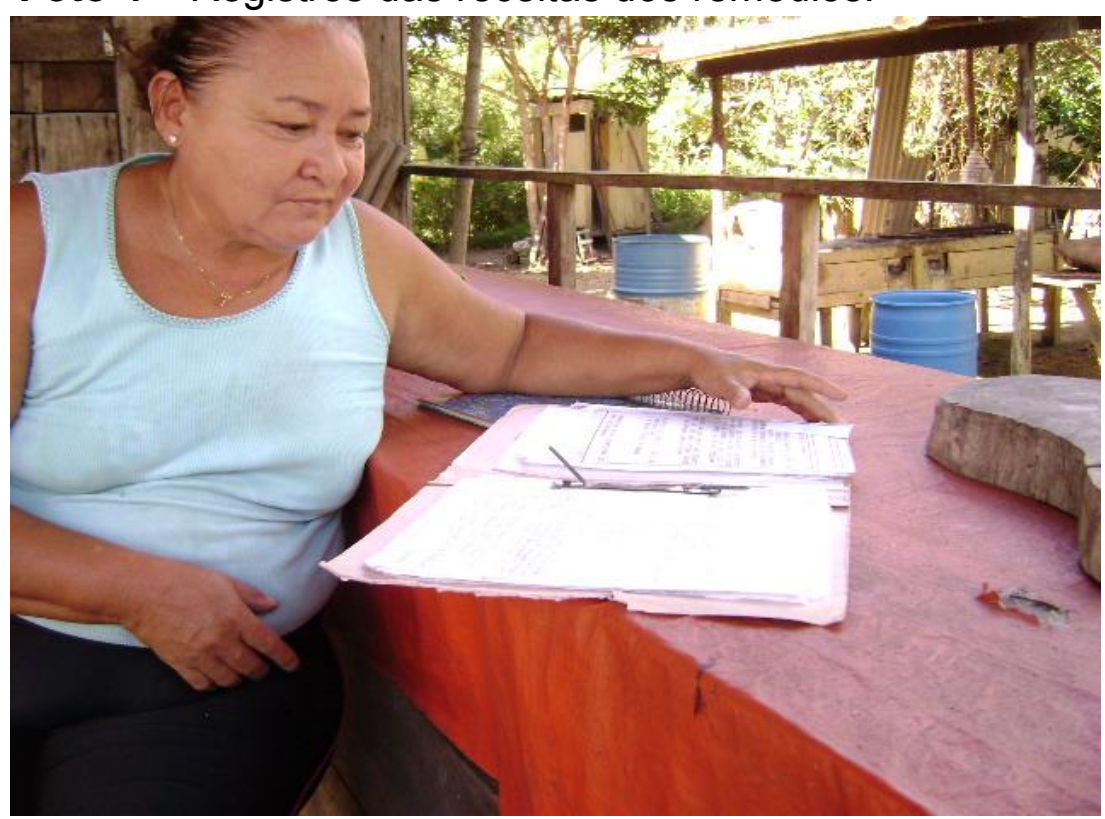

Fonte: Trabalho de campo, 2011-2012.

A família do Sr. Raimundo também passou a registrar as receitas de remédios em cadernos. Uma de suas filhas escrevia em um caderno enquanto a mãe ditava. No entanto, chegou um pesquisador se propondo a ajudá-las, levou os cadernos e publicou um livro com as informações cedidas por esta família. A partir de então, os conhecimentos ficaram somente na memória.

Realizar exames em postos de saúde e hospitais serve para detectar quais os problemas de saúde, mas o tratamento considerado adequado é feito com plantas, de acordo com o depoimento da Sra. E. C.

Olha eu sou assim, se eu tenho uma dúvida eu gosto de ir no hospital pra sabê o que eu tenho e aí eu entro no meu remédio, olha eu tive três cistos, aí o médico me deu noventa dias, se eu não ficasse boa em noventa dias eu ia perder as minhas duas mamas, dois cistos nos seios e um na barriga, então ele ia fazê uma limpeza geral, ia tirá as duas mamas, ia tirá o útero, ia tirá tudo. Aí ele foi passou um remédio, nesse período que eu tava fazendo o tratamento, apareceu uma reportagem que a graviola era muito boa, que ela combatia os cistos e ela agia no corpo do ser humano como a quimioterapia aí eu comi e passei mal, que chega meu corpo tremia, aí eu acho que não posso comê todo dia, comê um dia sim e outro não [na reportagem não falava como era para usar?] Não, só falava que podia comê, e não dizia quantas vezes, aí eu comi, aí eu comi um dia sim e outro não, aí pronto, quando interô os três meses que ele me deu aí eu fui lá com ele e disse que tava arriando... E ele disse que não tinha mais nenhum nódulo no meu seio porque tava se desfazendo e como tava se desfazendo não era preciso operá. Eu 
tinha que terminar o tratamento, podia parar de tomá o remédio eu ainda tomei a graviola nove meses aí saía um troço de mim dessa cor (preto) pela vagina, quando eu ficava menstruada, ele disse que tinha sair, ele disse: olha vai sair não sei por onde [em qual programa a senhora viu a reportagem?] olha eu não lembro, passou na globo, na A crítica (nome da afiliada do SBT no Amazonas) que era o SBT, passou no treze que é a BAND, foi geral, sabe?

Percebe-se, portanto, a influência que a mídia exerce no aprendizado dos remédios. Nesse sentido, as pesquisas sobre os remédios são uma prática cotidiana, ou seja, é importante estar atento a qualquer receita em qualquer lugar. Trata-se da difusão do saber popular.

A preservação de espécies nos quintais é influenciada por conhecidos que identificando a planta dizem qual a sua importância, isso foi verificado no depoimento do Sr. Z. D. V.

Essa pranta aqui tamém é boa, foi um cunhecido meu que me indicô, eu num, sabia que pranta era essa aí eu ia arrancá ela daqui, eu ia fazê a casa pro meu minino bem aí onde ela tá. Aí ele disse: não cumpade deixa ela aí que ela é boa pra fazê reza. Essa aí é a teca, manda os espírito ruim pra longe, aí eu deixei. Quem mexe com os trabaio de macumba vem atrás dessa pranta.

Trata-se de uma classe que se reinventa, busca alternativas para suas dificuldades, traça estratégias para o problema de terras para os herdeiros, migram, subdividem o sítio, ensina valores. Como já discutido, a família é o centro de suas ações e em torno dela se estabelece uma ordem moral. Enfim, retratar o modo de vida camponês é pensar uma relação entre o conhecimento tradicional e o uso equilibrado da natureza. 
3.1 As políticas para as plantas medicinais.

Muito se fala de um potencial econômico da Região Amazônica, principalmente com relação à biodiversidade existente, mas pouco estudada e explorada. No entanto, a economicidade desses produtos é em pequena escala, ou seja, atende um mercado consumidor local, exceto por alguns frutos famosos como é o caso do açaí e cupuaçu. Em outros casos a relação de venda das plantas se estabelece a partir das relações de vizinhança e de parentesco, onde o camponês, possuindo um sítio, produz espécies de plantas medicinais e leva para a cidade por encomenda.

É com vistas a esse etnoconhecimento biodiverso, dito por alguns de tradicional, que o governo federal criou em 1996 a Política Nacional de Plantas Medicinais e Fitoterápicos (PNPMF); atendendo a uma recomendação da Organização Mundial da Saúde (OMS) de incentivo a produção, pesquisas em Ciência e Tecnologia para a fabricação de medicamentos a partir dos princípios ativos das plantas medicinais e venda de matéria-prima para as indústrias farmacêuticas,

\footnotetext{
O Brasil é o país de maior diversidade do planeta que associada a uma rica diversidade étnica e cultural detém um valioso conhecimento tradicional associado ao uso de plantas medicinais, tendo o potencial necessário para o desenvolvimento de pesquisas com resultados em tecnologias e terapêuticas apropriadas. (BRASIL, 2007, p.09).
}

A incapacidade de atendimento dos sistemas de saúde nos países pobres norteou o aproveitamento das plantas pela medicina moderna. Segundo a OMS grande parte da população dos países em desenvolvimento depende da medicina tradicional, tendo em vista que $80 \%$ desta população utilizam práticas tradicionais nos seus cuidados básicos de saúde e $85 \%$ destes utilizam plantas ou preparações a partir destas (BRASIL, 2007).

Para amenizar o problema de acesso aos serviços de saúde oferecidos pelo Estado para pessoas de baixa renda, a OMS recomendou a seus países membros que desenvolvam políticas públicas de apoio a projetos relativos à identificação, avaliação, preparo, cultivo e conservação de plantas medicinais, seja da mata nativa ou cultivadas. 
A importância atribuída ao uso de plantas ocorre em função dos benefícios imediatos oferecidos, assim diminuindo os custos com a compra de medicamentos, e também, através das informações desses usos seria possível se ter a noção de quais plantas poderiam conduzir ao descobrimento e catalogação de substâncias terapêuticas.

A implantação dos conhecimentos e remédios oriundos das plantas é uma estratégia de alcance mundial da OMS para fortalecer o sistema de saúde dos países membros. Há também a importância comercial das espécies, nesse sentido, pensa-se que os estudos sobre biodiversidade com ênfase nas plantas medicinais pode ser um dos fatores de dinamização do processo produtivo regional nos países pobres.

Essa política de valorização dos conhecimentos das plantas por instituições internacionais de saúde exerce influências sobre a política nacional brasileira, de forma que a proposta é popularizar e incentivar a produção de remédios feitos parcial ou totalmente com as plantas medicinais de eficácia comprovada. Espera-se que assim haja uma diminuição nos custos das medicações para a população de baixa renda e poder público, que distribui medicação nos hospitais e postos de saúde públicos.

Em 1978 a OMS e a UNICEF (Fundo das Nações Unidas para a Infância) promoveram uma conferência Internacional sobre Atenção Primária em Saúde em Alma-Ata, Genebra-Suíça. Essa política mundial visava,

\footnotetext{
Formulação de políticas e regulamentações nacionais referentes à utilização de remédios tradicionais de eficácia comprovada e exploração das possibilidades de se incorporar os detentores de conhecimento tradicional às atividades de atenção primária em saúde fornecendo-lhes treinamento correspondente. (OMS apud BRASIL, 2007, p.11).
}

Na tentativa de implementar essa política de saúde pública no Brasil foram criados os programas:

- Estudo de Plantas Medicinais de Investigação Clínica (1981);

- Programa de Pesquisa em Plantas Medicinais e Central de Medicamentos (1982);

- Relação Nacional de Medicamentos Essenciais (RENAME);

- Política Nacional de Assistência Farmacêutica (PNAF);

- Política Nacional de Ciência, Tecnologia e Informação em Saúde (PNCTIS);

- Agenda Nacional de Prioridades de Pesquisa em Saúde (ANPPS);

- Política Nacional de Práticas Integrativas e Práticas Complementares no SUS (PNPIPCS); 
- Política Nacional de Saúde (PNS)

- Complexo Produtivo de Saúde, Avaliação de Tecnologias e Economia da Saúde, Assistência Farmacêutica;

- Política Nacional de Plantas Medicinais e Fitoterápicos (PNPMF, Decreto Presidencial de 17 de Fevereiro de 2005). (BRASIL, 2007, p.30)

Para fomentar o cultivo, beneficiamento e exportação das plantas medicinais o governo federal buscou uma articulação interministerial para assegurar a constitucionalidade, legalidade e compatibilidade da Política Nacional de Plantas Medicinais e Fitoterápicos, com as diretrizes governamentais. Nesse sentido, podem-se citar os Ministérios envolvidos: Ministério da Agricultura, Pecuária e Abastecimento; Ministério do Desenvolvimento Social e Combate a Fome; Ministério do Desenvolvimento Agrário; Ministério do Desenvolvimento, Indústria e Comércio Exterior; Ministério da Integração Nacional; Ministério do Meio Ambiente e Ministério da Saúde.

Em escala municipal foi realizada, em agosto de 2007, a I Semana de Plantas Medicinais e Fitoterápicos, representando um marco para o incentivo ao cultivo de plantas medicinais em Manaus, bem como o uso e produção de matéria prima para a indústria farmacêutica. Na verdade, essa política segue as diretrizes da PNPMF instituída em 1970, quando a OMS criou o Programa de Medicina Tradicional.

Neste evento foi divulgada a lei municipal $\mathrm{n}^{\circ} 1.122$ que regulamenta a segunda semana do mês de maio como a semana das plantas medicinais. Diversos grupos foram convidados a participar deste evento. Dentre eles as farmácias caseiras ligadas à igreja católica, Ministério da Agricultura, Pecuária e Abastecimento, Ministério do Desenvolvimento Agrário, associação de agricultores da comunidade do Pau Rosa (PA Tarumã Mirim) e grupos da indústria farmacêutica (Botica da Família e Rede Fito Amazônia).

A abordagem principal se referia ao uso das plantas para a produção de remédios, diminuindo os custos das famílias com remédios e o incentivo aos agricultores para a produção de matéria prima para a indústria farmacêutica, em que foi alegado que a produção industrial de medicamentos a partir das plantas é baixo no Amazonas por não haver oferta de matéria prima suficiente para esse mercado considerado em expansão.

No entanto, a questão levantada pelos agricultores refere-se à impossibilidade de restringir a área plantada para as plantas medicinais, em detrimento dos gêneros 
alimentícios, somente para atender a essa possível demanda. A Sra. Creuza dos Santos, representando a comunidade Pau Rosa, afirmou,

\footnotetext{
"nós vamos depender da boa vontade da indústria pra comprar as plantas medicinais? Nem pensar, tá bom do jeito que tá, a gente leva os nossos remédios pra feira e a gente já tem até cliente que procura as nossas plantas. Comida é mais importante, vendendo ou não vendendo não estraga".
}

Nessa perspectiva, o campesinato deveria adequar as áreas de cultivo para gerar matéria prima para as indústrias farmacêuticas que receberiam incentivos fiscais por fazer parte do pólo industrial de Manaus. Assim, a produção camponesa seria subordinada ao capital.

O representante da indústria farmacêutica afirma que, por ser insuficiente a quantidade de matéria prima, não é vantajoso o investimento em pesquisas para a produção em larga escala de medicamentos, isto é, as comunidades rurais deveriam suprir a demanda de matéria-prima.

Para os camponeses o uso e conhecimentos das plantas não são encarados simplesmente como mercadorias para acumulação de capital, isto porque faz parte do seu modo de vida utilizar seivas, resinas, raízes, folhas, sementes, cascas. Seja para o preparo de remédios ou para tratamentos espirituais. Os elementos de seu cotidiano são levados ao mercado e não o contrário.

No caso dos camponeses da comunidade Pau Rosa, as plantas medicinais se tornaram um item de sua economicidade, por se tratar de uma demanda que varia de acordo com os pedidos feitos pelos consumidores diretamente para os produtores-feirantes. Por vezes essa relação se estabelece com o ensinamento de como utilizar as ervas, o preparo de chás. Isso faz com que os camponeses se sintam orgulhosos em deter e repassar tais conhecimentos. Numa perspectiva de mercado tais saberes seriam garantia de lucro, algo incompatível com a lógica camponesa.

É singular a relação estabelecida entre o campesinato e a natureza. O conhecimento sobre as plantas e os remédios provenientes destas faz dos grupos camponeses, referência quando se trata de estudos acerca do etnoconhecimento.

Prova disso são os relatos de como se iniciou as vendas de plantas. De acordo com o depoimento da Sra. M. A. M., 
Eu morava na Betânia (bairro) aí quando eu vim pro assentamento, ficava um tempo cá e outro lá no bairro, naquela época meus meninos era pequeno e estudava lá no bairro, aqui já tinha escola mais era muito dificultoso, quando chovia a estrada ficava lisa e ficava difícil pra passar, passo até no jornal as vezes que o ônibus tombou, aí eu achei melhó os menino ficar estudando lá e depois que ficasse mais grandinho trazia comigo pra cá. Nesse lá e cá as vizinha via os remédio que eu fazia aí elas pedia muda e pra trazer as folha, a casca, que elas comprava. Aí o povo pegava a fazer encomenda, aí eu vinha e trazia. Depois nós vendemos a casa pra comprar uma bomba d'água e melhorá a casinha do sítio, tem dois sobrinho meu que me ajuda além dos meus meninos. Agora que a gente tá indo pra feira a gente encontra os amigo lá e o povo também pergunta: cê tem tal planta? Aí a gente fala que tem aí eles fala pra gente trazer que quando a gente voltar eles procura nós. $E$ aí hoje a gente é conhecido pelas plantas de remédio que nós traz.

O uso medicinal de plantas e animais da biodiversidade é fruto de conhecimentos acumulados repassados ao longo das gerações, mas também da procura pela resolução de alguma enfermidade na qual os procedimentos de cura fogem a seu cabedal cultural.

No entanto, esse conhecimento até então menosprezado pela medicina moderna, atualmente vem se tornando objeto de debates acerca da propriedade intelectual (CASTRO, 2000). 


\section{CONSIDERAÇÕES FINAIS}

O espaço agrário amazônico vem passando por intensas transformações, principalmente no pós década de 1960. A entrada do capital internacional apoiado pelo Estado foi o responsável pelos processos de expropriação e exploração da sociedade amazônica.

A configuração do campo passou a apresentar um cenário de extrema violência contra camponeses, povos indígenas. Outro agravante que torna esta realidade ainda mais complexa se refere à estrutura fundiária extremamente concentrada no Brasil. Este fator direcionou para a Amazônia dois fluxos migratórios, do Nordeste e do Centro Sul.

No caso do Nordeste, os camponeses sem-terra, expropriados pela ação do latifúndio, se deslocaram para a Amazônia Oriental, sobretudo no estado do Pará, e integraram a mão de obra dos chamados "grandes projetos" do governo ditatorial sob o lema "terra sem homens para homens sem terra", em uma clara negação a existência dos povos amazônicos.

Enquanto isso, no Centro Sul as famílias camponesas, sem possibilidades de adquirir mais terras, foram então incentivadas a "colonizar" a Amazônia, na sua porção Ocidental, notadamente os estados de Rondônia, Acre e Sul do Amazonas.

Houve, portanto, a instalação de conflitos entre latifundiários e posseiros, posseiros e indígenas, latifundiários e indígenas. Nesse tocante, as políticas estatais em benefício do grande capital favoreceram tal situação.

Apesar das dificuldades pelas quais as populações locais estavam passando havia a preservação de seu modo de vida, os costumes eram defendidos, as estratégias de sobrevivência não sucumbiram à voracidade do capitalismo instalado na Amazônia.

As práticas de ajuda mútua, o conhecimento sobre o ambiente, a troca de saberes permitiu aos grupos camponeses se instalarem na região, mesmo que migrando constantemente. Em entrevista a um senhor que saiu do Maranhão e era peão do trecho, ao perguntar qual a sua trajetória até chegar à comunidade Pau Rosa no assentamento Tarumã Mirim, me foi afirmado o seguinte "quando a gente tem famia (família) a gente tem que se aquietá num canto".

A busca pelas melhorias fez com que famílias se deslocassem de várias partes do país em direção à Amazônia à procura da terra de trabalho. No caso da 
Amazônia Ocidental, Manaus-AM foi o principal destino e o crescimento populacional era atribuído, ao êxodo rural.

Em 1992 foi criado o Projeto de Assentamento Tarumã Mirim na área rural de Manaus, a ocupação da área por "posseiros" onde se encontra a comunidade Pau Rosa, área de estudo deste trabalho, despertou a entrada de outras famílias, nesse caso, os lotes foram ocupados por famílias selecionadas pelo INCRA e a efetivação dos posseiros como assentados.

As origens diversificadas dos camponeses assentados passaram a imprimir marcas culturais nas paisagens dos lotes, que pelo trabalho da família foi gradativamente se transformando em sítios (BOMBARDI, 2004, p.139). Nos momentos iniciais de chegada à comunidade, a produção de carvão foi a alternativa encontrada, enquanto isso, a produção era levada para o mercado por meio dos atravessadores e somente com a organização social em associações de produtores que os camponeses puderam levar sua produção diretamente às feiras em Manaus.

A produção camponesa não se restringia somente aos gêneros alimentícios típicos. As associações de produtores do Pau Rosa passaram a ser reconhecidos pelos produtos ligados ao etnoconhecimento, os remédios a partir de plantas são comercializados, as "garrafadas" e os xaropes, assim como cascas, resinas, folhas, frutos, cipós, e as mudas de plantas.

O modo de vida ligado ao etnoconhecimento é característica do campesinato residente na comunidade Pau Rosa. Os tratamentos de saúde e casos de cura de doenças são atribuídos aos conhecimentos tradicionais. Este campesinato recria suas práticas, pesquisa remédios, assiste jornais e apreende as propriedades das plantas e testam sua eficácia.

O etnoconhecimento camponês é rico, vinculado ao saber tradicional passado ao longo de gerações. Somam-se a isto as trajetórias de vida, que marcadas pela migração, estabelecem modos de vida em constante transformação. Isto quer dizer que não se pode pensar o campesinato como um grupo social estático.

São notáveis as transformações nos modos de vida do campesinato. A ideia equivocada de um grupo estático contrasta com a realidade de um campesinato atuante, onde o etnoconhecimento é parte da cultura e as trocas de saberes determinam os laços de solidariedade e a construção da vida. 


\section{REFERÊNCIAS}

AB'SÁBER, A. N. A região Amazônica. In: D'INCAO, Maria Ângela; SILVEIRA, Isolda M. da. (Org.). A Amazônia e a crise da modernização. Belém: MPEG, 1994. p.7784.

2003.

Os Domínios de Natureza no Brasil. $3^{a}$ ed. São Paulo: Ateliê Editorial,

Amazônia: do discurso à práxis. São Paulo: EDUSP. 2004.

AMAZONAS, Governo do Estado. Unidades de Conservação do Estado do Amazonas. Secretaria de Estado de Meio Ambiente e Desenvolvimento Sustentável. - Manaus: SDS / SEAPE, 2007.

ARBEX JR, J. Terra sem povo, crime sem castigo. In: TORRES, Maurício (Org.). Amazônia revelada: os descaminhos ao longo da BR 163. Brasília: CNPQ, 2005. p. 21-65.

ARRUDA, R.S.V. "Populações Tradicionais" e a proteção dos recursos naturais em unidades de conservação. In: DIEGUES, A.C. Etnoconservação: novos rumos para a proteção da natureza nos trópicos. $2^{\mathrm{a}}$ edição. São Paulo: Hucitec, NUPAUB-USP, 2000. p. $273-290$.

BENATTI, J. H. Aspectos jurídicos e fundiários da várzea: uma proposta de regularização e gestão dos recursos minerais. In: A questão fundiária e 0 manejo dos recursos naturais da várzea: análise para a elaboração de novos modelos jurídicos. BENATTI, José Heder (Org.). Manaus: Edições IBAMA / PROVÁRZEA, 2005. p. 77 - 100.

BOMBARDI, L. M. O Bairro Reforma Agrária e o processo de territorialização camponesa. São Paulo: Annablume, 2004.

BRANDÃO, C. R. A partilha da vida. São Paulo: Geic/Cabral Editora, 1995.

BRASIL, Ministério da Saúde. Secretaria de Ciência, Tecnologia e Insumos Estratégicos. Departamento de Assistência Farmacêutica. Política Nacional de Plantas Medicinais e Fitoterápicos. Brasília: Ministério da Saúde, 2006. 60 p. (Série B. Textos Básicos de Saúde).

CÂMARA FEDERAL. Relatório da Comissão Parlamentar de Inquérito destinada a investigar a ocupação de terras públicas na região amazônica. 2001. Disponível em: <http://arisp.files.wordpress.com/2009/10/33421741-relatorio-finalcpi-terras-amazonas-grilagem.pdf $>$. Acesso em: 16 nov. 2010.

CASTRO, E. Território, biodiversidade e saberes tradicionais. In: Etnoconservação: novos rumos para a proteção da natureza nos trópicos. $2^{a}$ edição. São Paulo: Hucitec, NUPAUB-USP, 2000. p. 165 - 182. 
CARVALHO, J. B. Desmatamentos, grilagens e conflitos agrários no Amazonas. Manaus: Editora Valer, 2010.

COLCHESTER, M. Resgatando a natureza: Comunidades tradicionais e áreas protegidas. In: DIEGUES, A.C. Etnoconservação: novos rumos para a proteção da natureza nos trópicos. $2^{\mathrm{a}}$ edição. São Paulo: Hucitec, NUPAUB-USP, 2000. p. 225 256.

COMUNIDADE RURAL. In: MOTA, M. Dicionário da terra. Rio de Janeiro: Civilização brasileira, 2005. p. 112.

CRUZ, N. Mortes rondam o campo. Amazonas Em Tempo, Manaus, 13 nov. 2011. Caderno Dia a Dia, p.c1.

DIEGUES, A. C. Etnoconservação da natureza: enfoques alternativos. In:

Etnoconservação: novos rumos para a proteção da natureza nos trópicos. $2^{a}$ edição. São Paulo: Hucitec, NUPAUB-USP, 2000. p. 1-46.

Os saberes tradicionais e a biodiversidade no Brasil. Brasília: Ministério do Meio Ambiente; São Paulo: USP, 2000.

D'INCAO, M. C. Teoria e prática no estudo do campesinato paraense. In: HEBÉTTE, Jean; MAGALHÃES, Sônia Barbosa; MANESCHY, Maria Cristina. No mar, nos rios e na fronteira faces do campesinato no Pará. Belém: EDUFPA, 2002. p. 9-27.

FERNANDES, B. M. MST: formação e territorialização. São Paulo: Hucitec, 1996.

GONÇALVES, C. W. P. Amazônia, Amazônias. $3^{\text {a }}$ ed. São Paulo: Contexto, 2010.

A violência que se esconde atrás êxito do modelo agro-exportador. In: Conflitos no campo. CANUTO, Antônio; LUZ, Cássia Regina da Silva; WISHINIESKI, Isolete (Org.). Goiânia: CPT Nacional Brasil, 2012. p. 73-82.

GRZYBOWSKI, C. Caminhos e descaminhos dos movimentos sociais no campo. $3^{\text {a }}$ ed. Petrópolis: Vozes, 1991.

GUERRA, A. T.; GUERRA, A. J. T. Novo dicionário geológico-geomorfológico. $6^{a}$ edição. Rio de Janeiro: Bertrand Brasil, 2008.

HÉBETTE, J.; ALVES, J.; QUINTELA, R. Parentesco, vizinhança e organização profissional na formação da fronteira amazônica. In: HEBÉTTE, Jean; MAGALHÃES, Sônia Barbosa; MANESCHY, Maria Cristina. No mar, nos rios e na fronteira faces do campesinato no Pará. Belém: EDUFPA, 2002. p. 175-202.

HÉBETTE, J. Cruzando a fronteira: 30 anos de campesinato na Amazônia. Belém: EDUFPA, 2004. v.3.

IBGE. Manual técnico da vegetação brasileira. Rio de Janeiro: IBGE, 1992. 
INCRA. Diagnóstico sócio econômico ambiental do Assentamento Tarumã Mirim. Manaus (AM). INCRA, 1999.

. O INCRA e o Assentamento. Disponível em: $\overline{<h t t p: / / w w w . i n c r a . g o v . b r / p o r t a l i n d e x . p h p ? o p t i o n ~=c o m d o c ~ m a n ~ \& l t e m i d=140>. ~}$ Acesso em: 07/08/2009.

LEFF, H. Epistemologia Ambiental. 5. ed. São Paulo: Cortez, 2010.

LEITE, A. M. C.; SAMPAIO, P. de J. B.; BARBOSA, A. P.; QUISEN, R. S. Diretrizes para 0 resgate e conservação da variabilidade genética de espécies amazônicas I - pau rosa. Manaus: Embrapa Amazônia Ocidental, 1999. 43p.

LORENZI, H. Plantas medicinais no Brasil, nativas e exóticas. Nova Odessa: Instituto Plantarum, 2008.

MACHADO, M. M. S.; SOUZA, S. C.; COSTA, R. C. Relações de produção e modo de vida no assentamento Tarumã Mirim, Manaus (AM). In: XIX Encontro Nacional de Geografia Agrária, n.19, 2009, São Paulo. Anais XIX ENGA: Laboratório de Geografia Agrária/USP: São Paulo, 2009, p.1-14.

MACHADO, M. M. S.; MATOS, L. L. A dinâmica espacial da produção camponesa no assentamento Tarumã Mirim - Manaus/AM. In: XVI Encontro Nacional de Geógrafos. n.16, 2010, Porto Alegre. Anais XVI ENG: AGB, 2010. p.1-8.

MARQUES, M. I. M. De sem terra a "posseiro", a luta e a construção do território camponês no espaço da reforma agrária: o caso dos assentados nas fazendas Retiro e Velha - GO. 2000. Tese (doutorado em Geografia Humana) Universidade de São Paulo, São Paulo.

MARTINS, J. de S. Os camponeses e a política no Brasil. $5^{a}$ edição. Petrópolis: Vozes, 1995.

. 0 cativeiro da terra. $6^{a}$ edição. São Paulo: Hucitec, 1996.

. Expropriação e Violência: a questão política no campo. $3^{\mathrm{a}}$ ed. São Paulo: Hucitec, 1991.

MARX, K. A ideologia alemã: Feuerbach - A Contraposição entre as cosmovisões materialista e idealista. Tradução de Frank Müller. São Paulo: Martin Claret, 2006. 145 p. Tradução de: Die Deutsche Ideologie, 1932.

MIRANDA, J. R. Glossário Ambiental. Campinas: Embrapa Monitoramento por Satélite, 2007. Apresenta o significado de capoeira. Disponível em:

<http://www.biodiversidade.cnpm.embrapa.br>. Acesso em: 20 nov. 2008.

MOURA, M. M. Os herdeiros da terra: parentesco e herança numa área rural. São Paulo: Hucitec, 1978. 
MOTTA, M. M. M. Direito à terra no Brasil: a gestação do conflito, 1795-1824. São Paulo: Alameda, 2009.

NEVES, A. L. Agroecologia e novos modelos de projetos de assentamento. [mensagem pessoal]. Mensagem recebida por <soldocarmo@gmail.com> em 01 ago. 2011.

NOGUEIRA, A.C.F; MAINBOURG, E.M.T. A comunidade do Pau Rosa/Amazonas e a relação entre natureza, cultura e o processo de saúde/doença. Saúde Soc., São Paulo, v.19, n.I, p.22-34, maio. 2010. Disponível em: $<$ www.revistasusp.usp.br/sausoc/article/download/29626/31495> Acesso em: 30 out. 2013.

OLIVEIRA, A. U. de. Amazônia: Monopólio, Expropriação e Conflitos. Campinas: Papirus, 1987.

A geografia das lutas no campo. São Paulo: Contexto, 2002.

Labur Edições, 2007.

Modo de produção capitalista, agricultura e reforma agrária. São Paulo:

Agricultura brasileira: transformações recentes. In: ROSS, Jurandyr Sanches (org.). Geografia do Brasil. São Paulo: EDUSP, 2009. p. 465-523.

POSEY, D. Etnobiologia: teoria e prática. In: Suma etnológica brasileira, I Etnobiologia. Belém: Editora UFPA, 1987.

RIBEIRO, B. G. Suma etnológica brasileira, I - Etnobiologia. Belém: Editora UFPA, 1987.

SANTOS, J. V. T. dos. Colonos do vinho: Estudo sobre a subordinação do trabalho camponês ao capital. São Paulo: Editora Hucitec, 1978.

SILVA, C. E. da. Alternativas socioambientais para a gestão comunitária no assentamento Tarumã Mirim, Manaus - AM. 2006. Dissertação (Mestrado em ciências florestais e ambientais). Universidade Federal do Amazonas, Manaus, 2006.

SOARES, M. A. V. A comunidade Novo Amanhecer do projeto de assentamento Tarumã Mirim. 2002. Monografia (Bacharelado em Geografia) - Universidade Federal do Amazonas, Manaus, 2002.

SOUZA, S. do C. A comunidade Pau Rosa no assentamento Tarumã Mirim, Manaus-AM. 2008. Monografia (Bacharelado em Geografia) - Universidade Federal do Amazonas, 2009.

SURGIK, A. C. S. Estudo jurídico para a várzea amazônica. In: A questão fundiária e o manejo dos recursos naturais da várzea: análise para a elaboração de novos modelos jurídicos. BENATTI, José Heder (Org.). Manaus: Edições IBAMA / PROVÁRZEA, 2005. p. 15-32. 
TAVARES, L. Da seiva ao sangue. In: Conflitos no campo. CANUTO, A.; LUZ, C. R. da S.; WISHINIESKI, I. (Org.). Goiânia: CPT Nacional Brasil, 2012. p. 18-21.

TRICART, J. Ecodinâmica. Rio de Janeiro: IBGE, 1977.

THOMPSON, E. Costumes em comum: estudos sobre a cultura popular tradicional. São Paulo: Companhia das letras, 1998.

TOCANTINS, L. O rio comanda a vida: uma interpretação da Amazônia. Rio de Janeiro: Civilização Brasileira, 1961.

WORTMANN, E; WORTMANN, K. O trabalho da terra. Brasília: Editora UNB, 1997. WOORTMANN, K. Com parente não se neguceia: o campesinato como ordem moral. In: Anuário Antropológico 87. Brasília: Editora UNB, 1990. 


\begin{abstract}
ANEXOS
Anexo A - Conflitos no campo Amazonas.

Jornal Amazonas Em Tempo. Caderno Dia a Dia, p. C1. Manaus, domingo, 13 de novembro de 2011.
\end{abstract}

\title{
Escrito por Náferson Cruz
}

\section{Mortes rondam o campo}

Passava de $21 \mathrm{~h}$ do dia 31 de maio deste ano, quando dois pistoleiros se hospedaram em um pequeno hotel no município de Lábrea, a 610 quilômetros de Manaus. O objetivo era matar o pastor Antônio Vasconcelos, 55, que morava em uma reserva extrativista distante da sede municipal. A investida criminosa só não deu certo porque os comunitários do município souberam da presença dos pistoleiros e deram cobertura ao pastor, que foi transferido para outra cidade.

Dois dias depois, membros da Força Nacional de Segurança Pública, por meio de uma medida vinculada na 'Operação em Defesa da Vida', que atua nos conflitos agrários, chegaram ao município para dar proteção ao missionário religioso. Mesmo diante de todo aparato militar, os pistoleiros, antes de deixarem a cidade, não se intimidaram e mandaram um recado ameaçando a família.

A mesma situação viveu a agricultora Nilcilene Miguel de Lima, 45, presidente da associação Deus Proverá, localizada também no município de Lábrea. Em maio deste ano ela foi obrigada a se ausentar de suas atividades porque corria o risco de morte. A perseguição começou após a denúncia de retirada ilegal de madeira na região. "Precisei me esconder que nem uma caça ameaçada. Mas, antes de fugir fui espancada, e minha casa foi incendiada. Estou pedindo socorro, não quero morrer", contou.

Mesmo sem proteção e vivendo escondida, a agricultora disse que não se arrepende de ter feito as denúncias.

As histórias de Antônio Vasconcelos e de Nilcilene Lima, são exemplos de muitos outros casos de lideranças comunitárias e ambientalistas ameaçadas de morte, devido a conflitos de terras com fazendeiros, grileiros, e madeireiros na Região Norte, segundo a Comissão Pastoral da Terra (CPT), no Amazonas.

\section{PISTOLAGEM}

O Amazonas registrou quatro mortes nos últimos cinco anos: Gedeão Rodrigues da Silva (2006), Francisco da Silva (2007), Gênesis Félix (2008) e Adelino Ramos (2011) foram vítimas de pistolagem.

Segundo dados da instituição, 46 trabalhadores rurais e ambientalistas integram a 'lista negra' dos ameaçados de morte no Estado do Amazonas, entretanto apenas o pastor Antônio Vasconcelos e Nilcilene Lima recebem atualmente proteção da Força Nacional de Proteção aos Defensores dos Direitos Humanos (PPDDH).

De acordo com a coordenadora regional da CPT, Auriédia Marques da Costa, outros 45 ameaçados podem sucumbir a qualquer momento.

Ela ressalta que os moradores de assentamentos rurais sofrem perseguição constante por parte dos grupos de pistoleiros e milícias armadas compostas por 'jagunços', contratados para praticar os crimes. "Essas pessoas estão lutando pela erradicação do trabalho escravo, a reforma agrária em conflitos fundiários, e buscam a qualidade de vida aos menos favorecidos", disse Auriédia.

Durante a entrevista, Auriédia lembrou do último crime de pistolagem na região, o assassinato do líder do Movimento Camponês Corumbiara (MCC), Adelino Ramos, o Dinho, que atuava no município de Lábrea. "Em julho de 2010 ele denunciou as ameaças sofridas para a Comissão Nacional de Violência no Campo, mas nada adiantou. A proteção chegou tarde", contou. 
A coordenadora da CPT-AM, Marta Valéria Cunha, também, lamenta a situação. Ele informou que até parentes próximos aos protegidos estão deixando a cidade e procurando abrigos em outros Estados por causa das ameaças. De acordo com a comissão, de 1985 até abril deste ano, em todo o país ocorreram 1.580 mortes no campo. Só nos Estados que fazem parte da Amazônia Legal, neste período foram contabilizados 641 casos de violência no campo, com 918 mortes. Destes, somente 27 casos foram a julgamento, o restante segue impune.

\begin{tabular}{|l|}
\hline \multicolumn{1}{|c|}{ Lista de morte } \\
Apuí - 3 ameaçados \\
Canutama - 2 ameaçados \\
Humaitá - 1 ameaçado \\
Itacoatiara - 6 ameaçados \\
Lábrea - 12 ameaçados \\
Manaus - 8 ameaçados \\
Manacapuru - 2 ameaçados \\
Novo Airão - 6 ameaçados \\
Presidente Figueiredo - 4 ameaçados \\
Santo Antônio do lçá - 1 ameaçado \\
Tonantins - 1 ameaçado \\
Fonte: CPT Amazonas
\end{tabular}




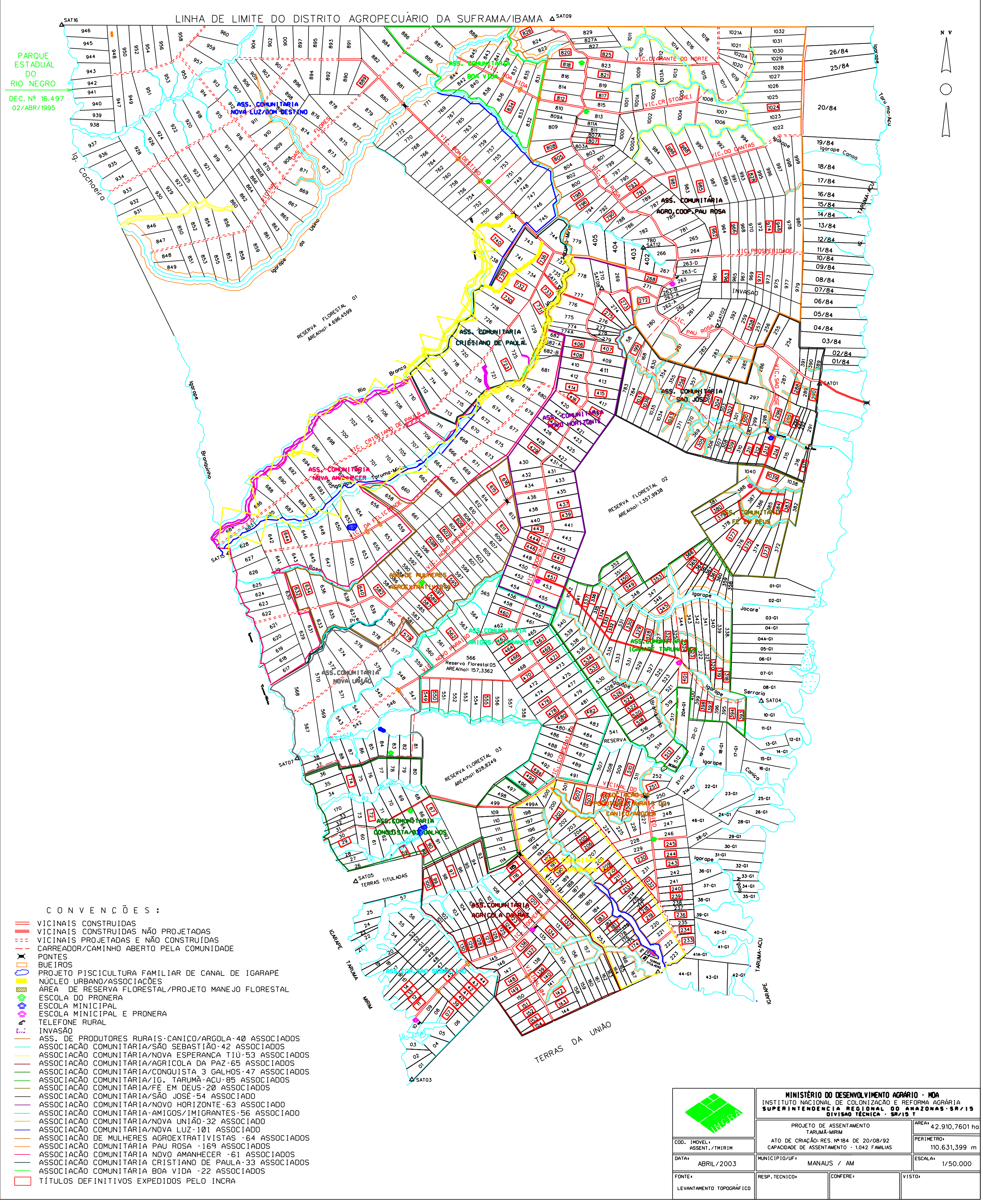


Anexo C - Situação dos projetos de Reforma Agrária.

MINISTEFIO DO DEBEN WOLVIMENTO AGRARIO - MDA

INSTITUTO HACIONAL DE COLONIZACAO E REFOFMA AGRARIA - NCRA

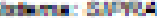

farte: Di

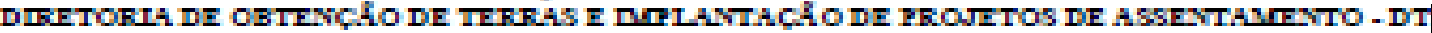

hathe ins

Dons =0u-sol1

\begin{tabular}{|c|c|c|c|c|c|c|c|c|c|c|c|c|c|c|c|c|}
\hline \multirow{3}{*}{$\begin{array}{l}\text { Coselyo do } \\
\text { Propto }\end{array}$} & \multirow{3}{*}{ Derominus ls so Prefels } & \multirow{3}{*}{ Mpo } & \multirow{3}{*}{ Fane } & \multirow{3}{*}{ Muricipts } & \multirow{3}{*}{ 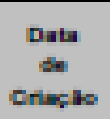 } & \multirow{3}{*}{$\begin{array}{l}\text { Capa } \\
\text { d. } \\
\text { cast }\end{array}$} & \multirow{3}{*}{$\begin{array}{l}\text { Dent- } \\
\text { fellarib }\end{array}$} & \multirow{3}{*}{ man } & \multirow{3}{*}{$\begin{array}{l}\text { Taps- } \\
\text { grafus }\end{array}$} & \multirow{3}{*}{ ATES } & \multicolumn{3}{|c|}{ Emiss fo Dosum, } & \multirow{2}{*}{\multicolumn{3}{|c|}{$\begin{array}{c}\text { Intritivintura } \\
\text { nask: }\end{array}$}} \\
\hline & & & & & & & & & & & aton & Berkugion & DaF & & & \\
\hline & & & & & & & & & & & Apoibs & Matcongt: & & A & $\mathbf{R}$ & E \\
\hline
\end{tabular}

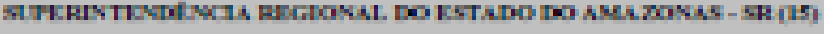

\begin{tabular}{|c|c|}
\hline Amotsono & 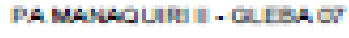 \\
\hline Amotsios & PA MAHAO LIH I - GLLEA DE \\
\hline Amotion & 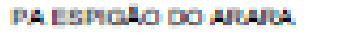 \\
\hline Amocutaos & PA BOUA \\
\hline Amoteino & PAPAHA \\
\hline Amationo & 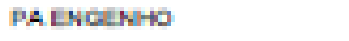 \\
\hline Amotiloo & PACAnha \\
\hline Amoromo & PAPACL \\
\hline Amocosos & PA. pocimito \\
\hline Amorntoo & PAPASILLO \\
\hline Amocenos & PA RAERII \\
\hline Amoction & PAPAQULOUIA \\
\hline Amosemo & PA. FO PAMDO \\
\hline Amoction: & PAAUUDABAS \\
\hline Amosions & PAALLAKG. \\
\hline Amocosion & PA LLALH \\
\hline Anoctiono & PABAD FuACISED \\
\hline Amonotion & PA AOUL BDLACA. \\
\hline Amoritos & PACANOAS \\
\hline Anocriono & 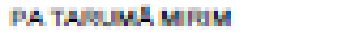 \\
\hline Amocouno & PAACAUI \\
\hline Anoctotion & PA BAGTO ANT CNID \\
\hline Ancongono & PA MATLPI \\
\hline Amocrios & PA.PUKLILAL. \\
\hline Amoct1000 & PA. WOWTL \\
\hline 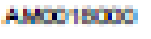 & PA BAMANO \\
\hline Amorinos & PAIMOHA \\
\hline Amotemos & P.A BLHLMI \\
\hline 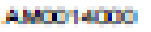 & PA RONA HLSECHELA \\
\hline
\end{tabular}

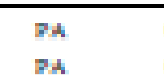

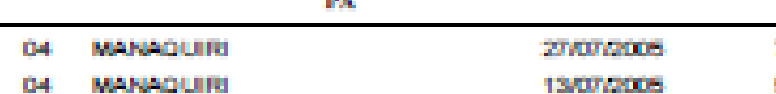

it camino

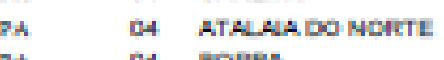

a4 ITHOGATLERE

is etring

a) Lenta

ie cumeno

a. manaus

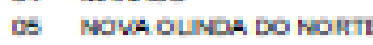

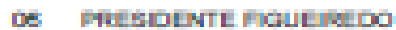

a) MANACANLIHL

if MALES

ite LANuAA

os Gevitiat

ai Manaus

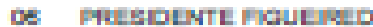

de manaus

De povo an giane

oe vanaus

is Mavicon:

oe вони

oe Bocapo actu

ie aLTARS

ie ITAGotrina

de etrung

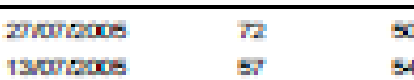

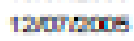

19730\%

isitiane

Disका

ज्ञाता

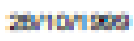

ISToned

1Taving

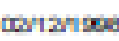

Danave

zingues

sacunges

ivarios

matumese

arming

Hinges

monise

crmengo

minges

aravise

suminge:

sumines:

nownen

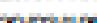

Mushis

13 Tensol

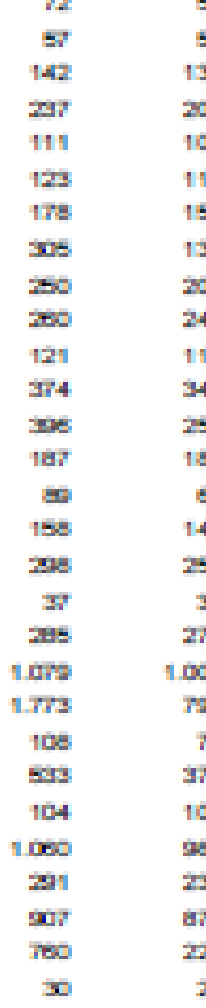

\begin{tabular}{|c|c|}
\hline 5 & 4 \\
\hline$=4$ & 4 \\
\hline 15 & 4 \\
\hline טD & 4 \\
\hline 108 & 4 \\
\hline 17 & 4 \\
\hline 154 & $\mathbb{N}$ \\
\hline 13 & $\mathrm{~N}$ \\
\hline xy & $\mathrm{N}$ \\
\hline 24 & $s$ \\
\hline ins & $\mathbf{N}$ \\
\hline 340 & $\mathbf{N}$ \\
\hline$=0$ & $\mathrm{~N}$ \\
\hline 101 & 4 \\
\hline$a$ & $\mathrm{~N}$ \\
\hline $1+4$ & $\mathbf{N}$ \\
\hline 15 & N \\
\hline$x$ & 4 \\
\hline 224 & $\mathbf{N}$ \\
\hline 1004 & 4 \\
\hline$m$ & N \\
\hline$\pi$ & $\mathrm{M}$ \\
\hline $3 r$ & 4 \\
\hline 10 & $\mathbf{N}$ \\
\hline gei & $\mathbf{s}$ \\
\hline 20 & 4 \\
\hline ars & $\mathbf{M}$ \\
\hline 202 & $\mathrm{M}$ \\
\hline$F$ & \\
\hline
\end{tabular}

Lyeres: Taudoproptro tio. - Em totimga

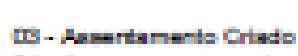

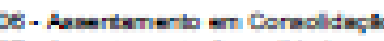

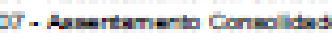

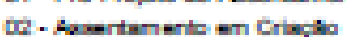

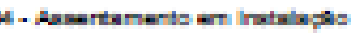

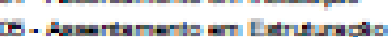

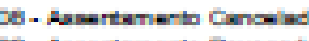

Dap:

mitises

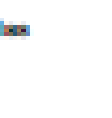

(2)

\author{
- matruthura: \\ - - merpia disto
}


MIFIS TEFIO DO DESEF WOLVMENTO AGRAFIO - MDA

IFSTITUTO HACIONAL DE COLONIZACLO E REFOFMA AGRARIA - NACRA

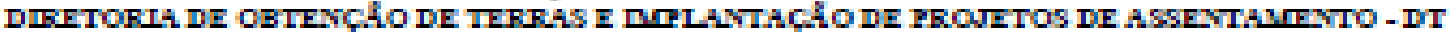

Bistere: Surva

Farta: Di

Newes be as

Drstantsin

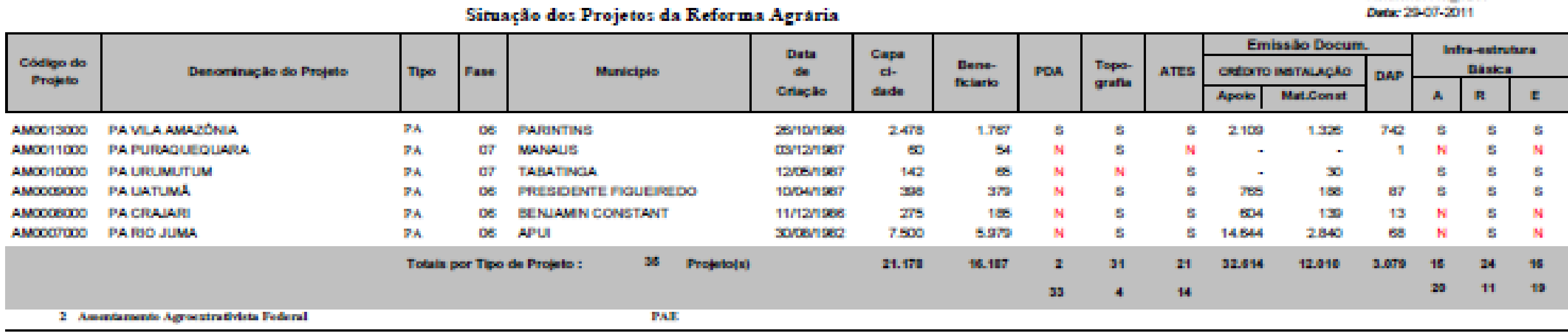

\section{AMOITOOOO PAL LADO DO MCAUA}

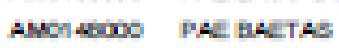

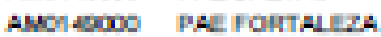

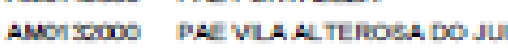

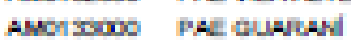

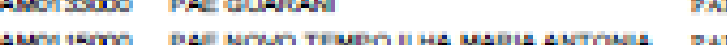

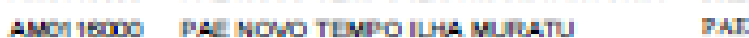

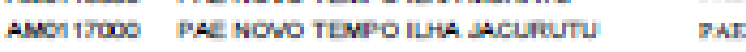

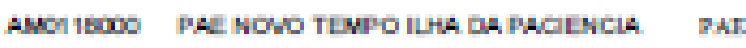

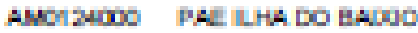

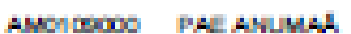

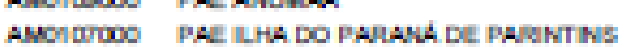

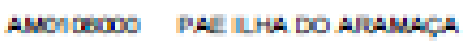

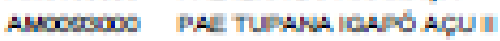

A woom PAL HOHO HOH LETL

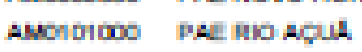

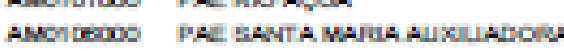

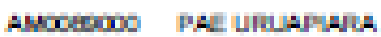

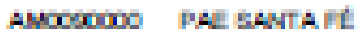

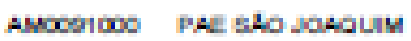

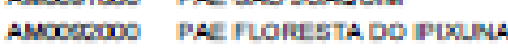

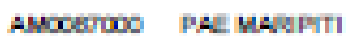

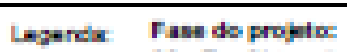

Ba - In toteris.

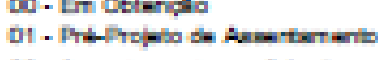

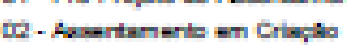

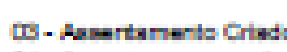

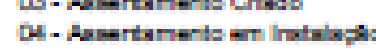

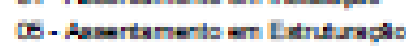

Fat

(1) MANiconat

(a) Makicones.

as Mancolue

14. GANTE ANTONO DO ICA

a. Matus:

04 inandusa

4 intandusa

(04) inandusa

4 IIANDLSA

a4 Eonts

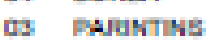

G4 ELNAMF CONSTHAT

04 etrima

04 HUMUTA

at gamutaha

a4 HUM⿻上丨

a4 HUMATA

a4 HUMUTA

04 HUMATI

a4 HUM⿻上丨

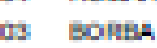

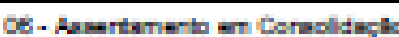

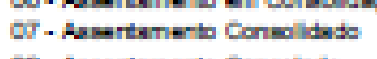

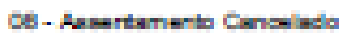

co-manrtaterb bevogeds

\begin{tabular}{|c|c|c|c|c|c|c|c|c|c|c|}
\hline 150 & 42 & $\mathbb{N}$ & $M$ & $M$ & . & . & & $\mathrm{h}$ & 4 & $\mathbb{N}$ \\
\hline 100 & $x$ & $\mathrm{~s}$ & 4 & $\mathrm{~A}$ & . & . & & $\mathrm{h}$ & $\mathrm{s}$ & $\mathrm{s}$ \\
\hline 100 & $x$ & $s$ & $\mathbf{M}$ & $\mathbf{A}$ & - & $=$ & & $\mathrm{h}$ & 4 & $\mathbb{N}$ \\
\hline 300 & 45 & $\mathrm{M}$ & $s$ & $\mathbf{A}$ & . & . & & $\mathrm{h}$ & $\mathrm{s}$ & $\mathbf{N}$ \\
\hline 700 & $18 \pi$ & 4 & $\mathbf{N}$ & $\mathbf{N}$ & - & - & & $\mathrm{h}$ & 4 & $\mathbb{A}$ \\
\hline$=$ & 5 & 4 & $\mathbf{M}$ & $\mathbf{M}$ & - & - & & $\mathrm{h}$ & $\mathrm{N}$ & $\mathbb{N}$ \\
\hline 110 & 74 & 4 & $\mathbf{M}$ & $\mathbf{M}$ & - & - & & $\mathrm{h}$ & $\mathrm{A}$ & $\mathbb{N}$ \\
\hline 100 & 20 & 4 & $\mathbf{N}$ & $\mathbf{N}$ & - & - & & $\mathrm{h}$ & $\mathrm{s}$ & $\mathbf{A}$ \\
\hline 20 & 21 & $\mathrm{~s}$ & $s$ & $\mathbf{A}$ & . & $=$ & & $\mathrm{hi}$ & $\mathrm{A}$ & $\mathbb{N}$ \\
\hline $\mathrm{so}$ & 10 & 4 & $s$ & $\mathbb{N}$ & - & - & & $\mathrm{k}$ & N & $\mathbb{N}$ \\
\hline 150 & $1 x$ & 4 & $\mathbb{N}$ & $\mathbb{N}$ & - & - & & $\mathrm{h}$ & $\mathrm{s}$ & $\mathbf{A}$ \\
\hline 5 & 8 & 4 & $\mathrm{H}$ & 4 & 2 & $=$ & & $\mathrm{h}$ & $\mathrm{s}$ & $\mathbf{s}$ \\
\hline 300 & \pm & 4 & $s$ & $\mathbf{N}$ & - & - & & $\mathrm{h}$ & N & $\mathbb{A}$ \\
\hline 100 & ๆ & 4 & $\mathrm{M}$ & $\mathbf{M}$ & $=$ & $=$ & & $\mathrm{h}$ & $\mathrm{s}$ & $\mathbf{A}$ \\
\hline 5 & 45 & 4 & $\mathbf{4}$ & $\mathbf{A}$ & . & . & & $\mathrm{h}$ & $\mathrm{N}$ & $\mathbf{A}$ \\
\hline 144 & 4 & 4 & 4 & $\mathbb{N}$ & . & . & & $\mathrm{h}$ & $\mathrm{s}$ & $\mathrm{A}$ \\
\hline 150 & Ias & $\mathrm{A}$ & $s$ & $M$ & - & . & & $\mathrm{h}$ & $\mathbf{4}$ & $\mathbf{A}$ \\
\hline 270 & 28 & 4 & $\mathrm{~A}$ & $\mathrm{~A}$ & . & . & & $\mathrm{h}$ & $\mathrm{N}$ & $\mathbf{s}$ \\
\hline 5 & 5 & $\mathrm{~N}$ & $\mathbf{M}$ & $\mathbf{A}$ & - & - & & $\mathrm{h}$ & $\mathbf{s}$ & $\mathbb{N}$ \\
\hline 300 & 10 & $\mathrm{~A}$ & $\mathbf{4}$ & $M$ & - & . & 12 & $\mathrm{~h}$ & $\mathbf{4}$ & $\mathbf{A}$ \\
\hline 170 & $\pi$ & 4 & $s$ & $\mathbf{A}$ & - & . & & $\mathrm{hi}$ & 4 & $\mathbb{N}$ \\
\hline 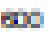 & 54 & $\mathrm{~s}$ & $\mathrm{~N}$ & $\mathrm{M}$ & . & . & & $\mathrm{h}$ & $\mathrm{s}$ & $\mathrm{N}$ \\
\hline
\end{tabular}

DaP:

DAP:

Intriesatrutur:

A. - hau

Pape 2 of 1 


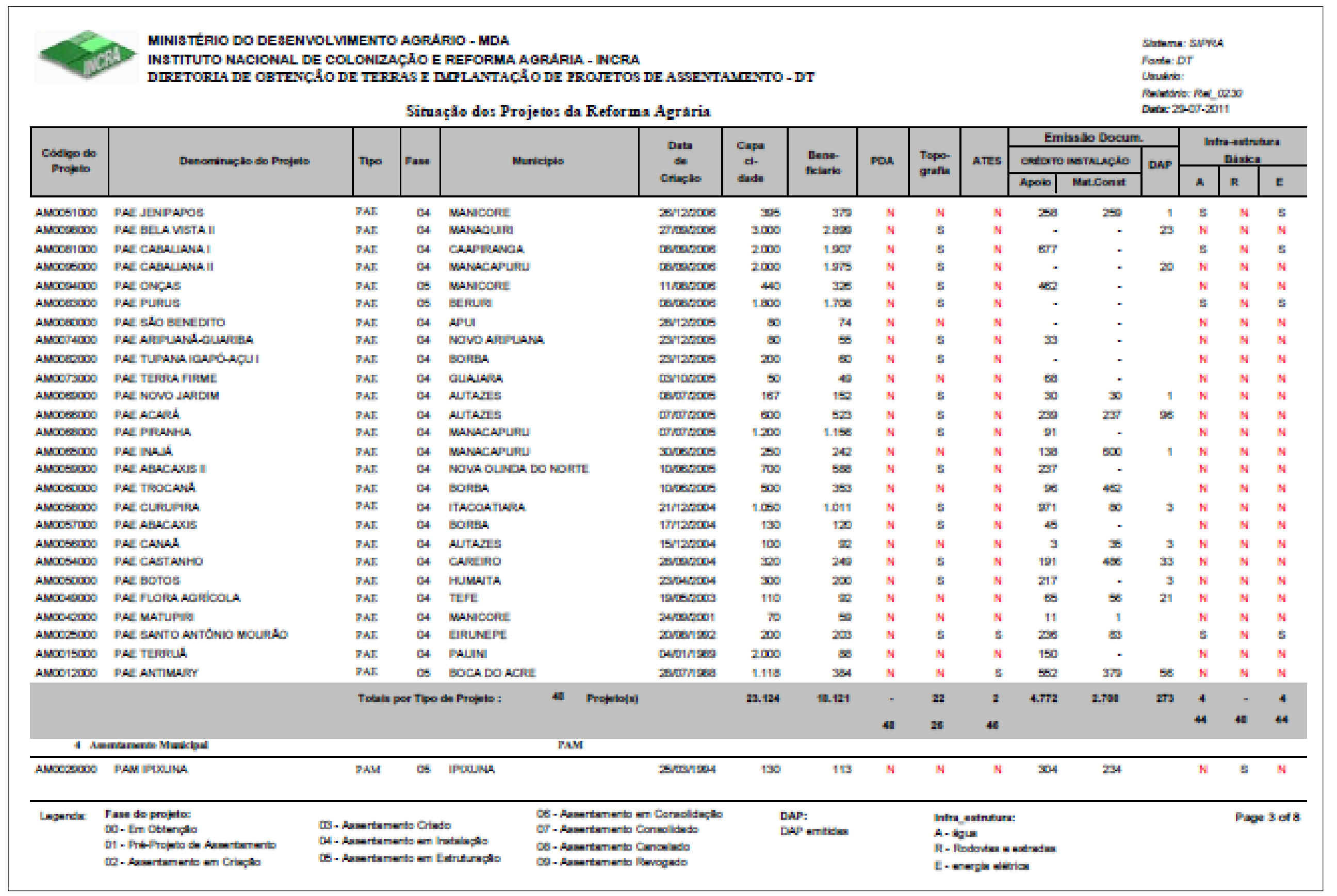


MINIS TERIO DO DESEN NOLVIMENTO AGRAFIO - MDA

IN3TITUTO NACIONAL DE COLONIZACGAO E REFORMA AGRARIA - NCRA

DIRETORIA DE OBTENC..

saten: supee

lante: Dr

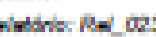

$0.000-20$

\begin{tabular}{|c|c|c|c|c|c|c|c|c|c|c|c|c|c|c|c|c|}
\hline \multirow{3}{*}{$\begin{array}{l}\text { Codese do } \\
\text { Drapto }\end{array}$} & \multirow{3}{*}{ Denominas bo do Projeto } & \multirow{3}{*}{ npo } & \multirow{3}{*}{ rase } & \multirow{3}{*}{ Municipto } & \multirow{3}{*}{$\begin{array}{c}\text { Data } \\
\text { of } \\
\text { Crieglo }\end{array}$} & \multirow{3}{*}{$\begin{array}{l}\text { Capa } \\
\text { d. } \\
\text { cade }\end{array}$} & \multirow{3}{*}{$\begin{array}{l}\text { Dene:- } \\
\text { feciarbo }\end{array}$} & \multirow{3}{*}{ pou } & \multirow{3}{*}{$\begin{array}{l}\text { Topo- } \\
\text { grafa }\end{array}$} & \multirow{3}{*}{ ATts } & \multicolumn{3}{|c|}{ Emiss So Docum } & \multirow{2}{*}{\multicolumn{3}{|c|}{$\begin{array}{c}\text { Intra-entnanara } \\
\text { nanka }\end{array}$}} \\
\hline & & & & & & & & & & & \multicolumn{2}{|c|}{ catorno netratacho } & \multirow{2}{*}{ DEP } & & & \\
\hline & & & & & & & & & & & Apoit & Mat:Const & & a & $\mathbf{n}$ & E \\
\hline & & Tolat & or The & 1 & Propetolus & 13 & 11 & - & - & - & 208 & 234 & & - & 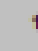 & - \\
\hline & & & & & & & & 1 & 1 & 1 & & & & 1 & . & 1 \\
\hline
\end{tabular}

7 Amentarante Cunds

NCa

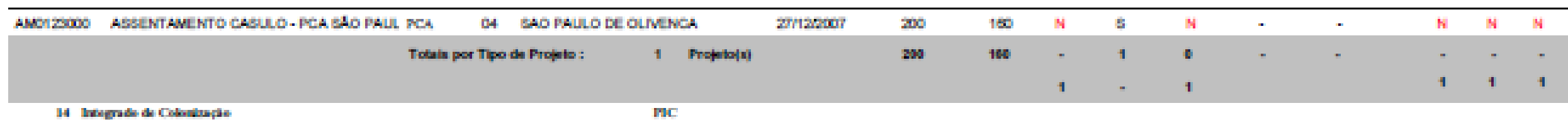

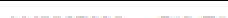

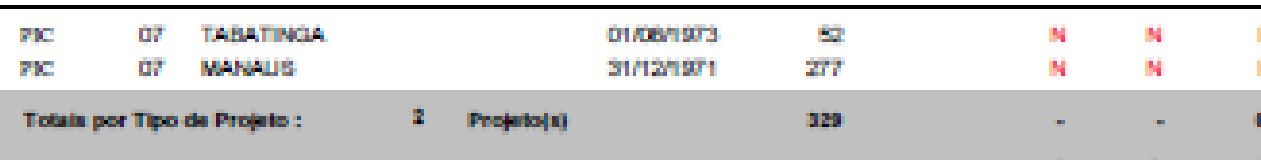

AMOOCEODO PC BELAVITA

Tolain por Tipo de Propits:

Frs

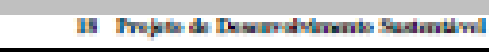

\section{AMOT QDOOO PDE ITALEAO}

AMOI UEDOOO PDE LADO DO MIVA

AMCI 2000 PDE BATATA

AMOIZONO PDE COSTA DO CALERARO

AMOI SODO PDE LADO DO TUCUNAVEL

AMONSTODO PDE COSTA DO IRLANCUEA

AMOIXONO PDE NONO REMANEO

AMOr SODOO PDE AMATANI

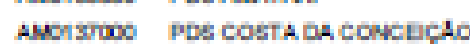

AMON 19000 PDE HOO TACANA

AMOIZ1000 PDE PRTMAVERG

AMOIZTOOO PDE BAMALIVA

AMONUSOOOO PDE REAUIDEOE.

AMccesono PDE CEREAO

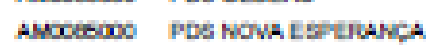

AMCoETOOO PDE RANTHA

\begin{tabular}{|c|c|c|}
\hline $7 \mathrm{DS}$ & 04 & cavetino \\
\hline $7 \mathrm{DS}$ & 04 & cavetino \\
\hline $\mathrm{mDS}$ & 04 & Cavetino \\
\hline $7 \mathrm{DS}$ & 04 & IRANDUEA \\
\hline $7 \mathrm{DS}$ & 04 & cavetino \\
\hline $7 \mathrm{DS}$ & 04 & Iranduea \\
\hline $7 \mathrm{DS}$ & 04 & ITACOATLAEA \\
\hline $7 \mathrm{Ds}$ & 04 & ITACOATILEA \\
\hline $7 \mathrm{DS}$ & 04 & ITACOATIREA \\
\hline $7 \mathrm{DS}$ & 04 & TABATINGCA \\
\hline $7 \mathrm{DS}$ & 04 & TAPALAA \\
\hline $9 \mathrm{Ds}$ & 04 & TAPALAA \\
\hline $7 \mathrm{Ds}$ & 04 & HUMATTA \\
\hline $7 \mathrm{DS}$ & 04 & LAEREA \\
\hline $7 \mathrm{DS}$ & 04 & Iflanduea \\
\hline $\mathrm{pDs}$ & as & POO PRETO DA EVA \\
\hline
\end{tabular}

Legertix rase do propetor

Do. Em Ctteripa

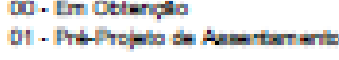

wis Aasertamerta Criedo

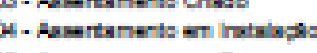

c6. Aamertanerta on Carooldack

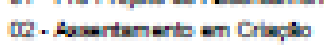

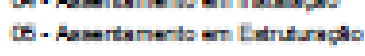

or. Aasortanerto Conwoldedso

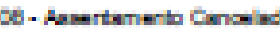

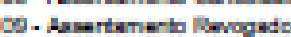

\begin{tabular}{|c|c|c|c|}
\hline 24062010 & 100 & 54 & $\mathrm{~s}$ \\
\hline 50120000 & $\infty$ & $\mathbf{x}$ & $\mathrm{s}$ \\
\hline 20120000 & $x$ & 24 & $\mathrm{~s}$ \\
\hline sorlabooe & $\infty$ & ES4 & s \\
\hline 20122000 & 100 & $\pi$ & s \\
\hline sorlasoxe & as & 48 & s \\
\hline soriarocea & $\$ 00$ & 10 & s \\
\hline soriaroced & so & 248 & s \\
\hline sor12000 & $\omega 00$ & sst & s \\
\hline 2 2112000\%? & 140 & 134 & s \\
\hline 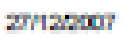 & 240 & 127 & s \\
\hline Znzascor & 500 & 313 & s \\
\hline 17 17000\%? & 250 & 174 & s \\
\hline zaverocor & 100 & 121 & s \\
\hline 2J100000 & $=$ & $z$ & s \\
\hline 20120000 & so & 28 & s \\
\hline
\end{tabular}

$S$
N
N
S
N
S
S
N
S
S
N
N
N
N
M
M

N
N
M
M
N
N
N
N
N
N
N
N
N
N
N
N

DAP:
DAP emritices

Intra estrutura:

A. ingue

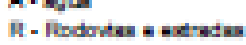

E. erergia cheria

Page 4 of 8 
MINISTÉTIO DO DEsEN WOLVIMENTO AGRAFIO - MDA

INSTITUTO NACIONAL DE COLONIZACAO E REFORMA AGRARIA - NCRA

DIEETORIA DI OBTENCAO DE TERRAS I DOPLANTACAO DE PRONETOS DE ASSEVTAMTITO - DT

Sisten: supea

Farte: Dr

Candis:

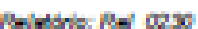

Duts. $2000 \cdot 2011$

Siruaçâo dos Projetos da Reforma Agraria

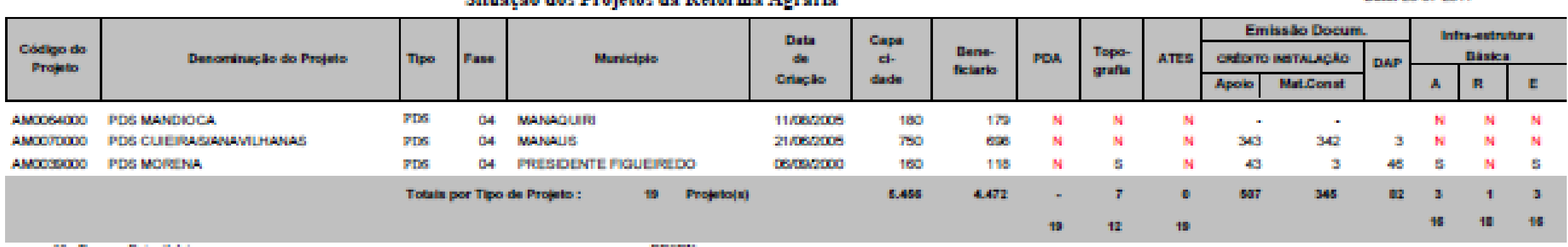

13 Rearos Eurathitat.

mestex

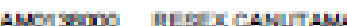

AMOIZTO00 REsEX ITUX

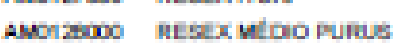

AMON 12000 hesex DO ho cheoono

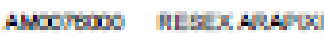

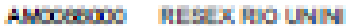

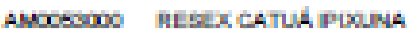

Aucouriag

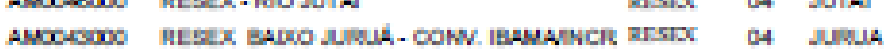

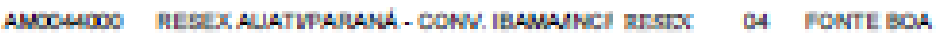

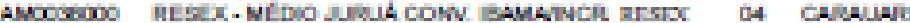

Tolain por Tipo de Propels :

$18 / 110000$

1 sicosoces

$1 \mathrm{scc0000 \textrm {C }}$

$12 \operatorname{111000}$

2

27120000

androwas

2row004

171230002

111230001

17izacor

\begin{tabular}{|c|c|c|c|c|c|c|c|c|c|c|}
\hline 200 & 153 & $\mathrm{~N}$ & $\mathrm{~N}$ & $\mathbb{N}$ & - & . & & $\mathrm{N}$ & $\mathrm{N}$ & $\mathrm{N}$ \\
\hline 300 & 180 & $\mathbf{N}$ & N & N & - & - & & $\mathrm{N}$ & $\mathbf{N}$ & $\mathbf{N}$ \\
\hline 1.400 & 1.314 & $\mathbf{N}$ & N & N & - & - & & N & $\mathbf{N}$ & $\mathbf{N}$ \\
\hline 200 & 158 & $N$ & N & N & - & - & & $N$ & $N$ & $N$ \\
\hline 200 & 184 & $\mathbf{N}$ & $\mathrm{N}$ & N & 1 & - & & N & $\mathbf{N}$ & $\mathrm{N}$ \\
\hline 138 & 5 & $\mathrm{~N}$ & N & N & . & . & & $\mathrm{N}$ & $\mathrm{N}$ & $N$ \\
\hline 400 & $3 x$ & $\mathbf{N}$ & N & $\mathrm{N}$ & $16 a$ & - & & $\mathrm{N}$ & $\mathbf{N}$ & $N$ \\
\hline 200 & 18 & $N$ & N & N & 123 & $1 x$ & & $N$ & $\mathrm{~N}$ & $N$ \\
\hline 200 & 253 & $\mathbf{N}$ & N & $\mathrm{N}$ & - & - & 48 & N & $\mathbf{N}$ & $\mathbf{N}$ \\
\hline 150 & $1 \geq$ & $\mathrm{N}$ & N & N & 68 & 5 & & N & $\mathrm{N}$ & $\mathrm{N}$ \\
\hline 20 & 28 & $N$ & N & 8 & - & - & & $N$ & $N$ & $\mathrm{~N}$ \\
\hline 500 & 514 & $\mathrm{~N}$ & $s$ & 8 & $\infty$ & - & & $\mathrm{N}$ & $\mathbf{N}$ & $\mathbf{N}$ \\
\hline \multirow[t]{2}{*}{4.321} & 2.600 & - & 1 & 2 & 457 & 102 & $\Leftrightarrow$ & - & - & - \\
\hline & & 12 & 11 & 10 & & & & 12 & 12 & 12 \\
\hline
\end{tabular}

21 Amentanane Nerubal

par

AMOI 50000 PQE CUMUCUETRE

TAF as Lenea

Par

AMONSIODO PAE RROICLA

PNF IS LEREA
PNF

31/000011

100

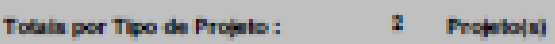

soviaroce

$200 \quad 10$

$200 \quad 168$

22 Noveda Narkial

novi

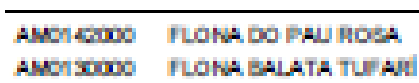

mover o4 MaLes

(2)

$\begin{array}{llllllll}N & N & N & - & - & N & N & N \\ N & S & N & - & - & N & N & N \\ - & 1 & 0 & - & - & - & - & - \\ 2 & 1 & 2 & & & 2 & 2 & 2\end{array}$

Lamertar rane do projetox

Do. Em Ottencipl:

TIONA O4 candtame

sov110000

300

200

$x^{2}+2-2$

DaP:

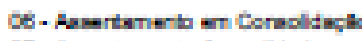

DAP:
DAP arriticas

of - Aasmrtanerto Conwolldeds

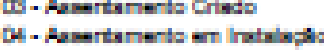

Co- Aasertanerb Concrido

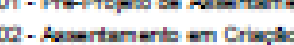

Co - Aasortamerta en Eatrutrapaso

Intra_estrutura:

A-kgua

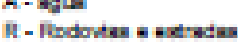

E. - mergia derio 


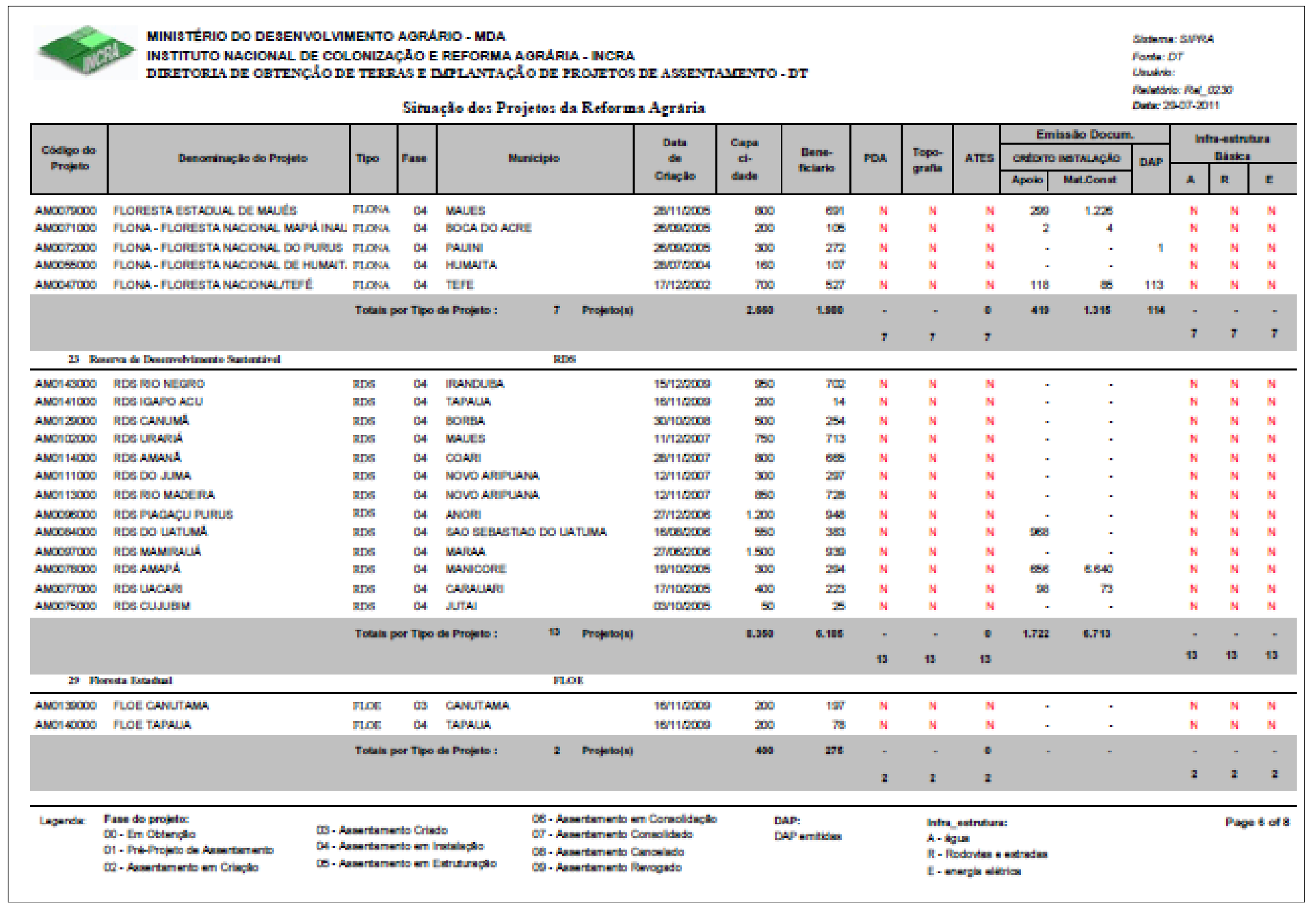




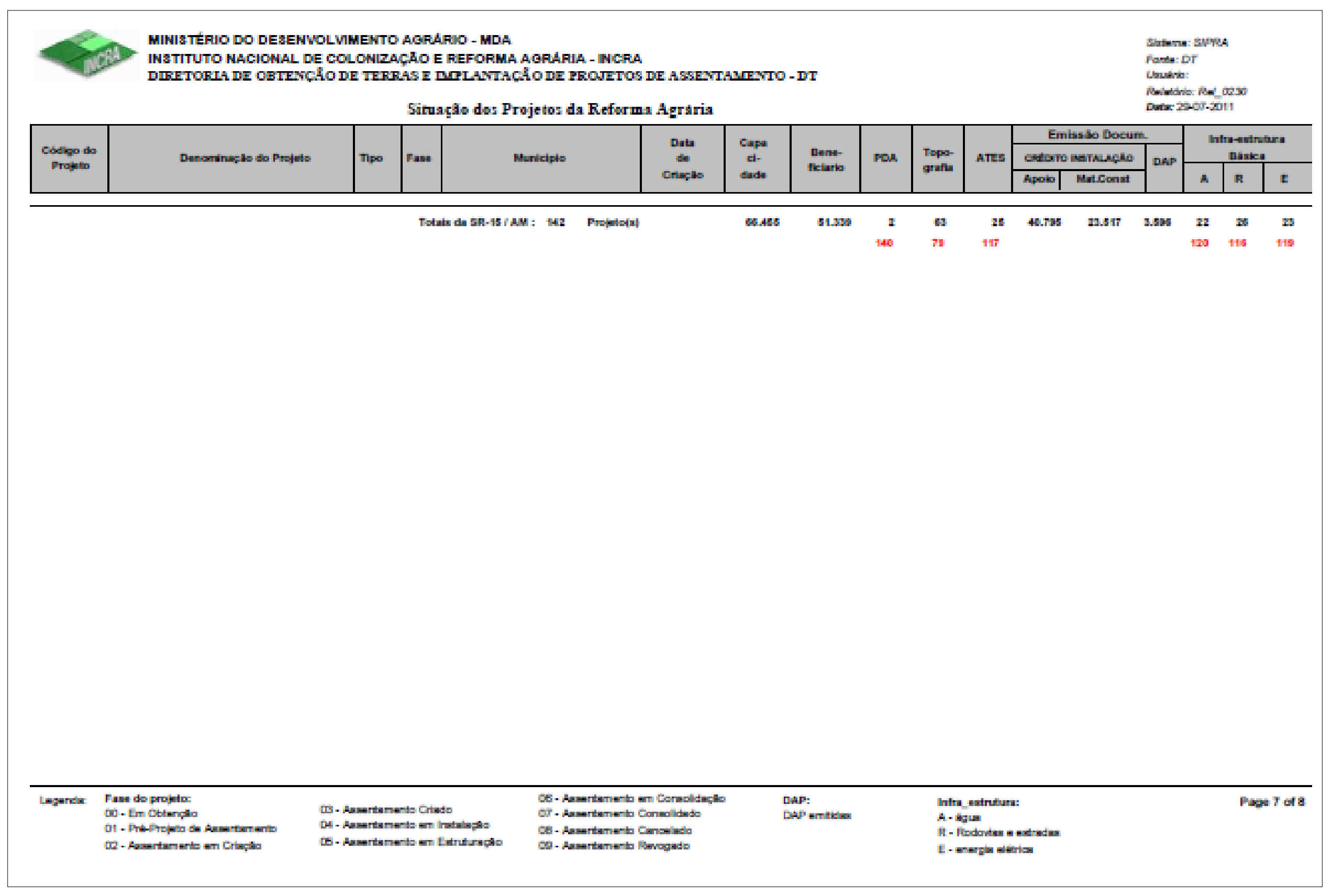




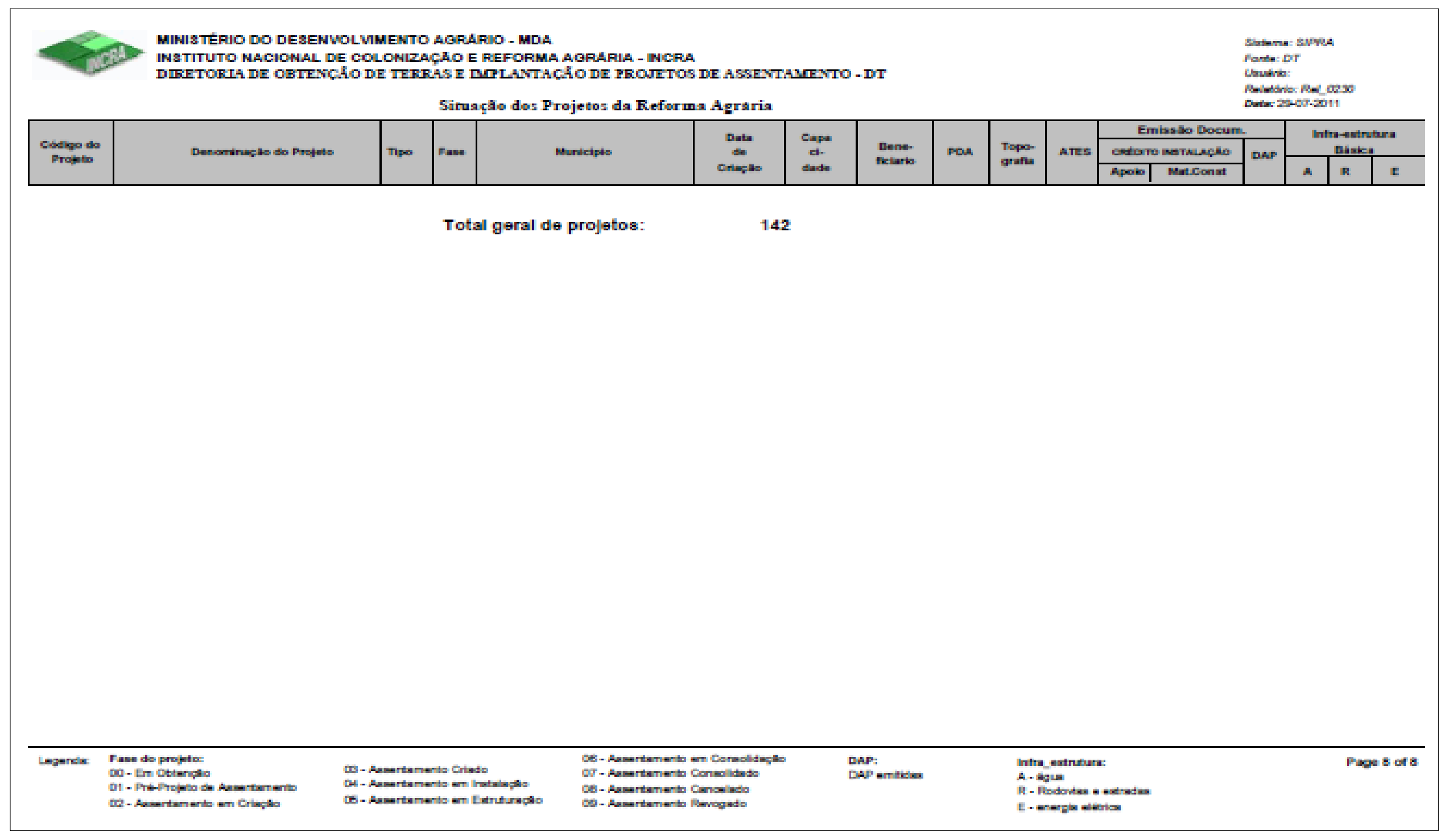

Fonte: INCRA, 2011. 
Anexo D - Decreto de criação da Margem Esquerda e Direita do Rio Negro.

\section{DECRETO N.⒗498 DE 02 de abril de 1995}

CRIA a área de Proteção Ambiental da Margem Direita do rio Negro, sito nos Municípios de Manaus, Novo Airão, Manacapuru, Presidente Figueiredo e Rio Preto da Eva e dá outras providências.

O Governador do estado do Amazonas, usando das atribuições que the são conferidas pelo Art. 23 itens VI e VII e Art. 24 itens VI e VII da Constituição Federal, e nos termos do Art. 5..$^{\circ}$ letra "a", da Lei 4.771 de 15 de setembro de 1965, e Artigo 5. ${ }^{\circ}$ letra "a" da Lei 5.197, de 03 de janeiro de 1967,

\section{DECRETA}

Art. 1. - Ficam criadas a Área de Proteção Ambiental da Margem Esquerda do Rio Negro com 740.757 ha e a Área de Proteção Ambiental da Margem Direita do Rio Negro com 554.334 ha, totalizando uma área global de 1.295.091 ha, que circundam o Parque Estadual do Rio Negro com limites e coordenadas geográficas seguintes:

§ 1. - A Área de Proteção Ambiental da Margem Esquerda tem seu início na boca do igarapé Tarumã-Açú, no ponto 1 , próximo à Manaus, situado ä $3^{\circ} 03^{\prime} 00^{\prime} \mathrm{S}$ de latitude e $60^{\circ} 06^{\prime} 30^{\prime \prime} \mathrm{WG}$ de longitude. Deste ponto, segue pelo tronco principal deste lgarapé até 0 ponto 2 de latitude $2^{\circ} 43^{\prime} 00^{\prime \prime} S$ de latitude e $60^{\circ} 04^{\prime} 50^{\prime \prime} W G$. Seguindo em linha reta até o ponto 3 , de latitude $2^{\circ} 35^{\prime} 40^{\prime \prime}$ e $60^{\circ} 01^{\prime} 20^{\prime \prime} W G r$ de longitude. Deste ponto, segue em linha reta até o ponto 4 , situado $2^{\circ} 19^{\prime} 50^{\prime \prime} S$ de latitude e $60^{\circ} 00^{\prime} 00^{\prime \prime} \mathrm{WG}$ de longitude. Deste ponto segue em linha reta até o ponto 5 , situado à $2^{\circ} 15^{\prime} 30^{\prime \prime} S$ de latitude e $60^{\circ} 01^{\prime} 20^{\prime \prime} W G r$ de longitude. Deste ponto segue em linha reta até o ponto 6, situado à $2^{\circ} 11^{\prime} 00^{\prime \prime}$ s e $60^{\circ} 11^{\prime} 00^{\prime \prime} \mathrm{WGr}$ de longitude. Deste segue pelo tronco principal do Igarapé Pidiuaú até o ponto 6 , situado à $2^{\circ} 37^{\prime} 00^{\prime \prime} \mathrm{S}$ de latitude e $60^{\circ} 37^{\prime} 15^{\prime \prime} \mathrm{WGr}$ de longitude. Deste ponto segue em linha reta até o ponto 7 , situado à $2^{\circ} 29^{\prime} 40^{\prime \prime}$ S de latitude e $60^{\circ} 47^{\prime} 41^{\prime \prime} \mathrm{WG}$ de longitude, no Rio Apuaú. Deste ponto, segue o tronco principal do Rio Apuaú até o ponto 8, na foz do Rio Negro. Deste ponto, segue a margem esquerda do Rio Negro, observando os limites da Estação Ecológica Anavilhanas, definido pelo decreto n. ${ }^{\circ} 86.061 / 81$, até o ponto 9 , situado à $3^{\circ} 02^{\prime} 11$ 'S de latitude e $60^{\circ} 22^{\prime} 38^{\prime \prime} W G r$ de longitude. Deste ponto, atravessa o Rio Negro, até o ponto10, situado à $3^{\circ} 02^{\prime} 11^{\prime \prime} S$ de latitude e $60^{\circ} 33^{\prime} 49^{\prime \prime} \mathrm{WGr}$ de longitude. Deste ponto, sobe perla margem direita do Rio Negro até o ponto 11, situado na foz do Igarapé Anajatuba no Rio Negro. Deste ponto, segue o tronco principal do Igarapé Anajatuba até o ponto 12 , situado à $2^{\circ} 43^{\prime} 05^{\prime \prime} \mathrm{S}$ de latitude e $60^{\circ} 55^{\prime} 14^{\prime \prime} \mathrm{WGr}$ de longitude. Deste ponto, segue em linha reta até o ponto 13 , situado à $3^{\circ} 11^{\prime} 23^{\prime \prime} S$ de latitude e $60^{\circ} 28^{\prime} 52^{\prime \prime} \mathrm{WGr}$ de longitude. Deste ponto, segue em linha reta até o ponto 
14 , situado à $3^{\circ} 06^{\prime} 30^{\prime \prime} \mathrm{S}$ de latitude e $60^{\circ} 22^{\prime} 58^{\prime \prime} \mathrm{WGr}$ de longitude. Deste ponto, segue em linha reta até o ponto 15 , situado à $3^{\circ} 06^{\prime} 30^{\prime \prime} S$ de latitude e $60^{\circ} 15^{\prime} 39^{\prime \prime} \mathrm{WGr}$ de longitude. Deste ponto, segue para o ponto 16 às margens do Rio Negro na longitude 60'15'39'WGr. Deste ponto, segue em linha reta, atravessando o Rio Negro até o ponto 1, fechando a primeira parte do Parque Estadual do Rio Negro.

§ 2 - O Parque Estadual do Rio Negro Setor Norte, tem início no ponto 1, situado na foz do Igarapé da Freguesia, perto da Cidade de Novo Airão. Deste ponto, segue pelo tronco principal do Igarapé da Freguesia até o ponto 2, situado na interseção entre o Igarapé da Freguesia e a linha de longitude 6059'36"WGr. Deste ponto, segue em linha reta até o ponto 3 , situado à $2^{\circ} 33^{\prime} 30^{\prime \prime S}$ de latitude e $61^{\circ} 05^{\prime} 00^{\prime} \mathrm{WGr}$ de longitude. Deste ponto, segue em linha reta até o ponto 4 , situado à $2^{\circ} 28^{\prime} 07^{\prime \prime} S$ de latitude e $61^{\circ} 08^{\prime} 27^{\prime \prime} W G r$ de longitude. Deste ponto, segue em linha reta até o ponto 5 , situado à $2^{\circ} 19^{\prime} 18$ "S de latitude e $61^{\circ} 07^{\prime} 31^{\prime \prime} \mathrm{WG}$ de longitude. Deste ponto, segue em linha reta até o ponto 6 localizado onde a linha de longitude de $61^{\circ} 26$ '54"WGr cruza o Rio Jaú. Deste ponto, desce o Rio Jaú e segue a margem direita do Rio Negro até a foz do Rio Unini, no ponto 7. Deste ponto, atravessa o Rio Negro seguindo em linha reta até o ponto 8 , situado no ponto mais meridional da Ilha da Cotia, no Rio Negro defronte a foz do Rio Unini. Deste ponto, segue em linha reta até o ponto 9, localizado onde o Rio Baependi cruza a linha de longitude $61^{\circ} 00^{\prime} 00^{\prime \prime} \mathrm{WGr}$. Deste ponto, segue Rio Baependi até sua foz no Rio Negro no ponto 10. Deste ponto, segue a margem esquerda, do referido rio, até o ponto 11 , $60^{\circ} 37^{\prime} 15^{\prime \prime} \mathrm{WGr}$ de longitude. Deste ponto segue a calha principal do lgarapé Pudiuaú , até o ponto 25 , situado à $2^{\circ} 35^{\prime} 27^{\prime \prime} S$ de latitude e $60^{\circ} 29^{\prime} 08^{\prime \prime} W G r$ de longitude. Deste ponto, segue em linha reta até o ponto 26 , situado na confluência do Rio Cuieiras com o Rio Branquinho. Deste ponto, segue em linha reta até o ponto 27 , situado à $2^{\circ} 43^{\prime} 00^{\prime \prime} S$ de latitude e $60^{\circ} 15^{\prime} 24^{\prime \prime} W G r$ de longitude. Deste ponto, segue em linha reta até o ponto 28 , situado à $2^{\circ} 48^{\prime} 20^{\prime \prime S}$ de latitude e $60^{\circ} 15^{\prime} 24^{\prime \prime} \mathrm{WGr}$ de longitude. Deste ponto, segue a calha principal do Igarapé Tarumã-Mirim até o ponto 29, localizado na boca do referido Igarapé. Deste ponto, segue a margem esquerda do Rio Negro até o ponto 1, na foz Tarumã-Açú.

§ 2ㅇ - A Área de Proteção Ambiental da Margem Direita tem início no Ponto 1 , localizado na margem direita do Rio Negro nas coordenadas $3^{\circ} 04^{\prime} 50^{\prime \prime} S$ de latitude e 60'15'39'WGr de longitude na margem. Deste ponto, segue em linha reta até o ponto 2 , situado à $3^{\circ} 06^{\prime} 30^{\prime \prime S}$ de latitude e 60¹5'39"WGr de longitude. Deste ponto, parte em linha reta até o ponto 3 , situado à $3^{\circ} 06^{\prime} 30^{\prime \prime} S$ de latitude e $60^{\circ} 22^{\prime} 58^{\prime \prime} \mathrm{WG}$ de longitude. Deste ponto, segue em linha reta até o ponto 4, situado à $3^{\circ} 11^{\prime} 23^{\prime \prime S}$ de latitude e $60^{\circ} 28^{\prime} 52^{\prime \prime} \mathrm{WGr}$ de longitude. Deste ponto, segue em linha reta até o ponto 5 , situado à $2^{\circ} 43^{\prime} 05^{\prime \prime S}$ de latitude e $60^{\circ} 55^{\prime} 14$ 'WGr de longitude. Deste ponto, segue em linha reta até o ponto 6 na foz do Igarapé Anajatuba. Deste ponto, segue beirando a margem direita do Rio Negro, observando os limites da Estação Ecológica de Anavilhanas, definidos através do decreto-lei n. ${ }^{\circ}$ 86.061/81, até o ponto 7, na foz do Igarapé da Freguesia, perto da cidade de Novo Airão situado à $2^{\circ} 36^{\prime} 40^{\prime \prime} S$ de latitude e 605' $10^{\prime \prime} \mathrm{WGr}$ de longitude. Deste ponto, segue o tronco principal deste Igarapé até o ponto 8 , na interseção entre o Igarapé da Freguesia e a linha de longitude 6059'37'WGr. Deste ponto, segue em linha reta até o ponto 9 , situado à $2^{\circ} 33^{\prime} 30^{\prime \prime} \mathrm{S}$ de latitude e $61^{\circ} 05^{\prime} 00^{\prime \prime} \mathrm{WG}$ de longitude. Deste ponto, seguem em linha reta até o ponto 10 , situado à $2^{\circ} 28^{\prime} 07^{\prime \prime S}$ de latitude e $61^{\circ} 08^{\prime} 27^{\prime \prime} \mathrm{WG}$ de longitude. Deste ponto, segue em linha reta até o ponto 11 , 
situado à $2^{\circ} 19^{\prime} 18^{\prime \prime} S$ de latitude e $61^{\circ} 07^{\prime} 31^{\prime \prime} W G r$ de longitude. Deste ponto, segue em linha reta até o ponto 12, situado onde o Rio Jaú cruza a linha de longitude $61^{\circ} 26^{\prime} 54^{\prime \prime} \mathrm{WG}$. Deste ponto, segue em linha reta até o ponto 13 , situado à $2^{\circ} 03^{\prime} 40^{\prime \prime S}$ de latitude e $61^{\circ} 36^{\prime} 30^{\prime \prime} \mathrm{WGr}$ de longitude. Deste ponto até o ponto 14 , situado à $2^{\circ} 27^{\prime} 00^{\prime \prime S}$ de latitude e $61^{\circ} 20^{\prime} 05^{\prime \prime} \mathrm{WGr}$ de longitude. Deste ponto, segue em linha reta até o ponto 15 , situado à $2^{\circ} 43^{\prime} 55^{\prime \prime} S$ de latitude e $61^{\circ} 16^{\prime} 30^{\prime \prime} \mathrm{WG}$ de longitude. Deste ponto, segue em linha reta até o ponto 16 , situado à $2^{\circ} 48^{\prime} 00^{\prime \prime} \mathrm{S}$ de latitude e 61012'30"WGr de longitude. Deste ponto, segue em linha reta até o ponto 17 , situado à $3^{\circ} 16^{\prime} 00^{\prime \prime} \mathrm{S}$ de latitude e $60^{\circ} 40^{\prime} 50^{\prime \prime} \mathrm{WGr}$ de longitude. Deste ponto, segue em linha reta até o ponto 18, situado à $3^{\circ} 19^{\prime} 10^{\prime \prime} S$ de latitude e 60³5'05"WGr de longitude, na margem esquerda do Rio Solimões. Deste ponto, segue a margem esquerda até o ponto 19, na confluência do Rio Solimões com o Rio Negro, situado à $3^{\circ} 09^{\prime} 10^{\prime \prime S}$ de latitude e $60^{\circ} 20^{\prime} 40^{\prime \prime} W G r$ de longitude. Deste ponto, segue a margem direita do Rio Negro, até o ponto 1.

Art. 2. - A Área de Proteção Ambiental da Margem Esquerda e da Margem Direita, destina-se a proteger e conservar a qualidade ambiental e os sistemas naturais ali existentes, visando a melhoria da qualidade de vida da população local e também objetivando a proteção dos ecossistemas regionais.

Art. 3.- - Cabe ao Instituto de Desenvolvimento dos Recursos Naturais e Proteção Ambiental do Estado do Amazonas - IMA/AM, a administração das Áreas de Proteção Ambiental criadas neste decreto.

Art. 4. - Não são permitidas nas Áreas de Proteção Ambiental APA's as atividades de terraplanagem, Mineração, dragagem e escavação que venham a causar danos ou degradação do meio ambiente e/ou perigo para pessoas ou para a biota.

Art. 5. - Para as atividades agrícolas ou pecuárias que existam ou venham a existir nas APA's, haverá Zonas de Uso Agropecuário, nas quais serão proibidos ou regulados os usos ou práticas capazes de causar sensível degradação do meio ambiente.

1. - Não é admitida nessas Zonas a utilização de agrotóxicos e outros biocidas que ofereçam riscos sérios na sua utilização, inclusive no que se refere ao seu poder residual. O Instituto de Desenvolvimento dos Recursos Naturais e Proteção Ambiental do Estado do Amazonas - IMA/AM relacionará as classes de agrotóxicos de uso permitido nas APA's.

2.․ - O cultivo da terra será feito de acordo com as práticas de conservação do solo recomendadas pelos órgãos oficiais de extensão agrícola

$3^{\circ}$ - Não será admitido o pastoreio excessivo, considerando-se como tal aquele que acelerar sensivelmente os processos de erosão.

Art. 6. - - Fica estipulado o prazo de 3 (três) anos para que o Instituto de Desenvolvimento dos Recursos Naturais e Proteção Ambiental do Estado do Amazonas - IMA/AM, promova a execução e aprovação do Plano Diretor das APA's da Margem Esquerda e Margem Direita do Rio Negro. 
Art. 7. - Este Decreto entra em vigor na data de sua publicação.

GABINETE DO GOVERNADOR DO ESTADO DO AMAZONAS, em Manaus, 02 de abril de 1995.

\section{AMAZONINO ARMANDO MENDES}

Governador do Estado do Amazonas

Fonte: IPAAM, 2012. 
Anexo E - Decreto sobre a criação da semana de plantas medicinais.

\section{Decreto $n^{\circ}$ 9.039, de 17 de maio de 2007.}

\section{Disciplina sobre a SEMANA DAS PLANTAS MEDICINAIS (fitoterapia) no município de Manaus e dá outras providências.}

O PREFEITO DE MANAUS, usando das atribuições que Ihe são conferidas pelo artigo 80, inciso IV da LEI ORGÂNICA DO MUNICÍPIO DE MANAUS.

FAÇO SABER que o Poder Legislativo decretou e eu sanciono a seguinte,

\section{LEI:}

Art. $1^{\circ}$ Fica estabelecida a segunda semana do mês de maio como a semana de plantas medicinais (fitoterapia), que deverá constar do calendário oficial de eventos do município de Manaus.

Art. $2^{\circ} \mathrm{A}$ semana da Fitoterapia terá como objetivos fundamentais:

I - abordar e discutir temas ligados à farmacologia, identificação botânica, usos e indicações, extração, óleos essenciais, cosmética, farmacognosia, fitoquímica, toxidade e toda gama de informações pertinentes à elucidação da fitoterapia;

II - informar, sensibilizar, conscientizar e mobilizar a opinião pública o uso de ervas e plantas medicinais com finalidades terapêuticas;

III - ampliar os conhecimentos técnicos dos profissionais da rede municipal de saúde por meio de cursos e workshops sobre fitoterapia;

IV - fomentar e estimular a divulgação de saberes locais sobre fitoterapia e etnobotânica;

V - incrementar hortas comunitárias orgânicas de ervas e plantas medicinais;

VI - estimular os postos de saúde da rede municipal a cultivarem, nos seus espaços, ervas e plantas medicinais;

VII - desenvolver em Manaus um centro metropolitano de divulgação da fitoterapia;

VIII - estimular os produtos orgânicos da Região, envolver e ampliar o cultivo sustentável de ervas e plantas medicinais como alternativa de renda e trabalho.

Art. $3^{\circ}$ VETADO.

Art. $4^{\circ}$ VETADO.

Art. $5^{\circ}$ As despesas decorrentes desta Lei serão consignadas no Orçamento-Programa do Município, suplementadas se necessário.

Art. $6^{\circ}$ Esta Lei entra em vigor na data de sua publicação, revogadas as disposições em contrário.

Manaus, 17 de maio de 2007.

JOSÉ MÁRIO FROTA MOREIRA

Prefeito de Manaus em exercício.

Fonte: Manaus, 2010. 